
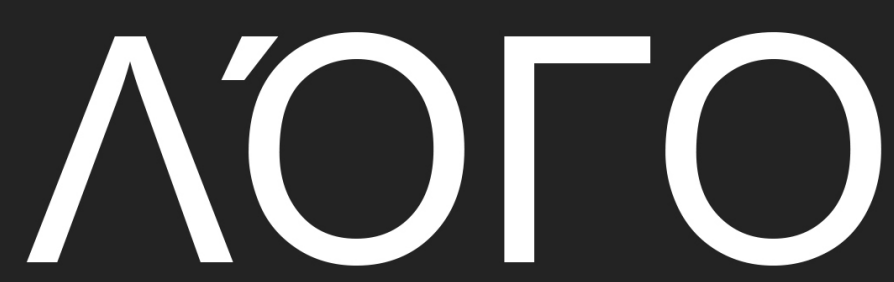

COLLECTION DE PAPIERS SCIENTIFIQUES



SUR LES MATÉRIAUX DE LACONFÉRENCE SCIENTIFIQUE ET PRATIQUE INTERNATIONALE

\title{
PROBLÈMES ET PERSPECTIVES D'INTRODUCTION DE LA RECHERCHE SCIENTIFIQUE INNOVANTE
} 29 NOVEMBRE 2019 • BRUXELLES, BELGIQUE —

\section{VOLUME 1}





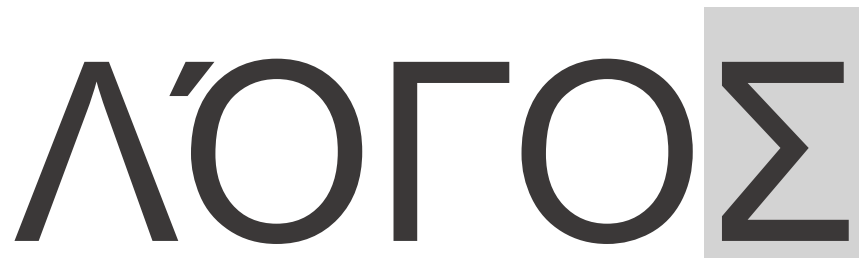

COLLECTION DE PAPIERS SCIENTIFIQUES

SUR LES MATÉRIAUX DE LA CONFÉRENCE SCIENTIFIQUE ET PRATIQUE INTERNATIONALE

«PROBLÈMES ET PERSPECTIVES D'INTRODUCTION DE LA RECHERCHE SCIENTIFIQUE INNOVANTE»

29 NOVEMBRE 2019

VOLUME 1

Bruxelles • Belgique 
P 93

Président du comité d'organisation: Holdenblat $M$.

Responsable de la mise en page: Kazmina $N$.

Responsable de la conception: Bondarenko I.

P 93 Problèmes et perspectives d'introduction de la recherche scientifique innovante: collection de papiers scientifiques

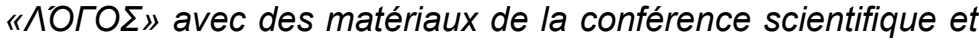
pratique internationale (Vol. 1), 29 novembre, 2019. Bruxelles, Belgique: Plateforme scientifique européenne.

ISBN 978-617-7171-89-7

DOI 10.36074/29.11.2019.v1

Les résumés et articles des participants à la conférence multidisciplinaire scientifique et pratique internationale «Problèmes et perspectives d'introduction de la recherche scientifique innovante», qui s'est tenue à Bruxelles le 29 novembre 2019, sont présentés.

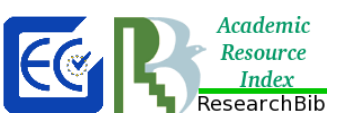

L'événement est inclus dans le catalogue des conférences scientifiques internationales, approuvé sur la plate-forme ResearchBib et certifié par Euro Science Certification Group norme scientifique SCC-2000.

Les documents de la conférence sont disponibles au public sous licence Creative Commons Attribution 4.0 International (CC BY 4.0).



and Researchers

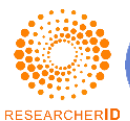

RESEARCHERID
La description bibliographique des documents de la conférence peut être téléchargée et indexée dans ORCID, Publons, Google Scholar, etc. 


\section{CONTENU}

\section{SECTION I. \\ SCIENCES ECONOMIQUES}

AGRARIAN RECEIPTS AS A FORM OF LENDING TO AGRICULTURAL PRODUCERS

Pecheniuk A., Rudyk V.

ASSESSMENT OF THE EFFECTIVENESS OF EU COUNTRIES NATIONAL INNOVATION SYSTEMS

Gnidina V.

DIAGNOSIS OF METHODS OF ESTIMATION OF EFFICIENCY OF TRANSPORT AND LOGISTICS SYSTEMS OF METALLURGICAL ENTERPRISES

Amelnitskaya E.

DIE EIGENSCHAFTEN EXISTIERENDER MARKETING-STRATEGIEN DES UNTERNEHMENS

Amelnytska M.

FORMATION OF PRINCIPLES OF ORGANIZATIONAL TRANSFORMATION OF NAFTOGAS GROUP

Ovetska 0 .

INTERNATIONAL TRADE AND FOREIGN TRADE POLICY OF UZBEKISTAN

Narziyev S.

SMМ-СТРАТЕГІЯ ЯК ЕФЕКТИВНИЙ ІНСТРУМЕНТ В РЕКЛАМНІЙ ДІЯЛЬНОСТІ ПІДПРИЕМСТВ

Москаленко М.М.

SOME WAYS TO IMPROVE THE PROFESSIONAL EDUCATION IN UKRAINE

Denchik I.

THE APPLICABILITY OF THE TAX REFORM ON THE IMPLEMENTATION OF THE DEDUCTIBLE CAPITAL TAX

Tarasiuk I.

THE UKRAINIAN "BASE EROSION AND PROFIT SHIFTING» PLAN IMPLEMENTATION PARTICULARITY

Danylenko V.

АКСЕЛЕРАЦІЯ ТА ІНКУБАЦІЯ БІЗНЕСУ: МЕТОДОЛОГІЧНІ ПІДХОДИ ТА ІНФОРМАЦІЙНИЙ ЧИННИК

Філіппов В.Ю. 
4 - Problèmes et perspectives d'introduction de la recherche scientifique innovante $\bullet$ Volume 1

АНАЛІЗ ЕФЕКТИВНОСТІ ВИКОРИСТАННЯ ЛІСОВИХ РЕСУРСІВ ВОЛИНСЬКОЇ ОБЛАСТІ

Батієвич Д.М.

АНАЛІЗ КОНКУРЕНТНОГО СЕРЕДОВИЩА ЯК ФАКТОР ЗАБЕЗПЕЧЕННЯ КОНКУРЕНТОСПРОМОЖНОСТІ ПІДПРИЕМСТВА Волошенко С.В.

ВІДКРИТІ ДАНІ ЯК ЗАСІБ СТВОРЕННЯ НОВОЇ ЦІННОСТІ ДЛЯ СУСПІЛЬСТВА

Івасюк Ю.О.

ВЛИЯНИЕ СТРУКТУРЫ ФАРМАЦЕВТИЧЕСКОГО РЫНКА И РЫНКА УСЛУГ КЛИНИЧЕСКИХ ИССЛЕДОВАНИЙ РОССИИ НА ВЫБОР СТРАТЕГИЧЕСКИХ НАПРАВЛЕНИЙ РАЗВИТИЯ ЛОКАЛЬНОЙ КОНТРАКТНОЙ ИССЛЕДОВАТЕЛЬСКОЙ ОРГАНИЗАЦИИ

Аронова Е.В.

ВПЛИВ ОБЛІКУ І ВНУТРІШНЬОГО КОНТРОЛЮ НА ФОРМУВАННЯ АМОРТИЗАЦІЙНОЇ ПОЛІТИКИ ПІДПРИЕМСТВА

Слєсар Т.М., Черненко А.О.

ЕЛЕКТРОННА КОМЕРЦІЯ ЯК СУЧАСНА ФОРМА ОРГАНІЗАЦІЇ БIЗHECУ

Яремко М.О., Лозовський О.М.

ЕТАПИ КАМЕРАЛЬНОЇ ПЕРЕВІРКИ ДЕКЛАРАЦІЇ З ПДВ

Гайсенок В.В.

ЗАХОДИ ІЗ ЗАБЕЗПЕЧЕННЯ КОНКУРЕНТНИХ ПЕРЕВАГ ОНЛАЙНРИТЕЙЛУ

Науково-дослідна група:

Чміль Г.Л., Олініченко К.С., Мороз Т.Б.

ІНФРАСТРУКТУРА ЯК ОДИН ІЗ ВАЖЛИВИХ ЧИННИКІВ РОЗВИТКУ ТУРИЗМУ В УКРАЇНІ

Кушніренко О.О., Малюта К.Г.

МАКРОПРУДЕНЦІЙНА ПОЛІТИКИ НАЦІОНАЛЬНОГО БАНКУ УКРАЇНИ

Андрющенко І.C.

МЕТОДОЛОГІЧНІ ЗАСАДИ ПРОЦЕСУ ФОРМУВАННЯ СТРАТЕГІЇ РОЗВИТКУ ПІДПРИЕМСТВА

Соколова Л.В., Стойка О.В.

МІЖНАРОДНИЙ ДОСВІД КЛАСТЕРИЗАЦІЇ ЕКОНОМІКИ

Ключенко А.В.

МІСЦЕ РЕСТОРАННОГО ГОСПОДАРСТВА В ІНДУСТРІЇ 
ГОСТИННОСТІ

Кушнір 0.0.

НЕЙРОМАРКЕТИГ, ЯК СКЛАДОВИЙ ЕЛЕМЕНТ МАРКЕТИНГОВИХ ДОСЛІДЖЕНЬ

Лабенська Ю.Д.

НАПРЯМИ ВДОСКОНАЛЕННЯ ОРГАНІЗАЦІЇ ФІНАНСОВОЇ ДІЯЛЬНОСТІ НА ПІДПРИЕМСТВІ

Науково-дослідна група:

Паньків Ю.І., Яцканич А.В., Гупаловська М.Б.

«НОВАЯ ЭКОНОМИКА»: СОЦИАЛЬНО-ЭКОНОМИЧЕСКАЯ ПРИРОДА

Зайцев А.К.

ОБЛІК ЗАЛУЧЕНОГО КАПІТАЛУ ПІДПРИЄМСТВА

Слєсар Т.М., Якубчик О.О.

ОПТИМІЗАЦІЯ СТРУКТУРИ БУХГАЛТЕРСЬКОГО БАЛАНСУ ЯК ФАКТОР ПІДВИЩЕННЯ ЛІКВІДНОСТІ ТА ПЛАТОСПРОМОЖНОСТІ ПІДПРИЕМСТВА

Гаспарян Г.К.

ОРГАНІЗАЦІЯ МАТЕРІАЛЬНО-ТЕХНІЧНОГО ПОСТАЧАННЯ ВИРОБНИЦТВА (ДЛЯ ВСІХ ПРОМИСЛОВИХ ПІДПРИЕМСТВ)

Якимів І.Б.

ОРГАНІЗАЦІЯ ТОВАРОПОСТАЧАННЯ ТА ШЛЯХИ ЗНИЖЕННЯ ВИТРАТ ТОРГОВЕЛЬНОГО ПІДПРИЕМСТВА

Поповський О.Ю.

ОСНОВНЫЕ ФАКТОРЫ МОТИВАЦИИ ЦИФРОВЫХ КОЧЕВНИКОВ

Андрушой К.Н., Фучеджи Н.Ф.

ОСОБЛИВОСТІ ДОСЛІДЖЕННЯ РИНКУ ПОБУТОВОЇ ТЕХНІКИ ТА ЕЛЕКТРОНІКИ (НА ПРИКЛАДІ КОМПАНІЇ «РЕКОРД»)

Овецька О.В., Атавін А.

ОСОБЛИВОСТІ НАУКОВО-ДОСЛІДНОЇ ДІЯЛЬНОСТІ МУЗЕЇВ

Пономарьова Г.В.

ОСОБЛИВОСТІ ОБЛІКУ ПОТОЧНИХ ФІНАНСОВИХ ІНВЕСТИЦІЙ

Сергійчук Н.А., Воляк Л.Р.

ОЦІНКА РИНКУ ГОТЕЛЬНО-РЕСТОРАННИХ ПОСЛУГ У МІСТІ ВІННИЦЯ

Задорожнюк Д.П., Мазуркевич I.O.

ПЕРСПЕКТИВИ РОЗВИТКУ ЕКСТРЕМАЛЬНОГО ТУРИЗМУ В УКРАЇНІ

Гуцол О.М. 
6 - Problèmes et perspectives d'introduction de la recherche scientifique innovante $\bullet$ Volume 1

ПОГЛЯД НА УДОСКОНАЛЕННЯ СИСТЕМ УПРАВЛІННЯ ПІДПРИЕМСТВОМ

Іванов А.B.

ПРАВОМІРНІ ІМПОРТНІ ОПЕРАЦІЇ НА ТЕРИТОРІЮ УКРАЇНИ БЕЗ BВЕЗЕННЯ ТОВАРУ

Омельчак В.Д.

ПРИНЦИПИ РОЗВИТКУ РИНКУ СІМЕЙНОЇ ОСВІТИ

Ахновська I.O.

ПРІОРИТЕТНІ НАПРЯМИ ГАРМОНІЗАЦІЇ МЕХАНІЗМУ ЦІНОУТВОРЕННЯ НАУКОВИХ ДОСЛІДЖЕНЬ І РОЗРОБОК В КОНТЕКСТІ ЄВРОІНТЕГРАЦІЙНОГО ВЕКТОРУ РОЗВИТКУ УКРАЇНСЬКОÏ НАУКИ

Коритник Л.П.

ПРОБЛЕМИ БЕЗПЕКИ В ГОТЕЛЯХ

Кушнір 0.0.

ПРОБЛЕМИ ЗБАЛАНСОВАНОСТІ ПЛАТІЖНОГО БАЛАНСУ УКРАЇНИ Джанумова Л.Т. Оскома О.В.

РЕСУРСНИЙ ПОТЕНЦІАЛ ПІДПРИЄМСТВА

Говорун В.В.

РОЛЬ МАРКЕТИНГОВОЇ ІНФОРМАЦІЇ У РОЗВИТКУ ВІТЧИЗНЯНОГО ПІДПРИЄМСТВА

Олійник В.M.

РОЛЬ ПОДАТКОВИХ НАДХОДЖЕНЬ У ФОРМУВАННІ ДОХІДНОЇ ЧАСТИНИ БЮДЖЕТУ

Іванова В.С.

СТРАТЕГІЧНЕ ПЛАНУВАННЯ ЕКОНОМІЧНОЇ АКТИВНОСТІ ПІДПРИЄМСТВ ТОРГІВЛІ

Кащена Н.Б.

СУБ'ЄКТИ ПУБЛІЧНОГО АДМІНІСТРУВАННЯ В СФЕРІ ОПОДАТКУВАННЯ

Голобородько Т.В. 


\section{SECTION I. SCIENCES ECONOMIQUES}

\section{AGRARIAN RECEIPTS AS A FORM OF LENDING TO AGRICULTURAL PRODUCERS} Candidate of Sciences (Economics), associate professor State Agrarian and Engineering University in Podilya Volodymyr Rudyk Doctor of Sciences (Economics), associate professor State Agrarian and Engineering University in Podilya

UKRAINE

Agrarian production is one of the key sectors of the Ukrainian economy. With some of the best soil fertility in the world, our country is a leading producer of such crops as sunflower, wheat, soybeans, and corn. The share of the agricultural sector in the gross domestic product of Ukraine in recent years is about $14 \%$, in addition, agricultural production is $38 \%$ of total exports.

However, the potential of the agricultural sector is not fully exploited. A significant increase in the efficiency of agricultural production in Ukraine is impossible without solving the problem of providing affordable loans to agricultural enterprises. For most farmers today, credit conditions are unbearable, and sometimes even bonded, forcing them to work at best at cost (if not at a cost). The situation is further complicated by the fact that banks, as a rule, require a loan (collateral, surety from another person, etc.). All this does not contribute to the development of an adequate level of lending in the market of agribusiness, which depends on seasonal phenomena, often forced to agree to unfavorable conditions, hoping for profit and timely settlement with creditors [1].

Therefore, it is important for the agricultural sector of Ukraine to find innovative financial instruments that would be useful and economically viable for both creditors and agricultural enterprises. One of the ways to solve this problem can be to apply in practice a mechanism of agrarian receipts, which is actively implemented with the support of the International Finance Corporation.

The concept of «agrarian receipt» was first introduced in Ukrainian legislation in connection with the adoption of the Law of Ukraine "On Agrarian Receipts» of 06.11.2012, which came into force on 19.03.2013. This law introduced a new mechanism for attracting funds for agribusiness. However, in practice, this tool came into force as early as 2015 after the adoption of a number of relevant by-laws.

According to the Law of Ukraine "On Agrarian Receipts», an agrarian receipt is a commodity order documenting the unconditional obligation of the debtor, which is secured by a pledge, to deliver agricultural products or to pay cash under the conditions specified therein [2].

The receipt is considered issued from the date of its registration in the Register of Agrarian Receipts, the administrator of which is the state enterprise «Agrarian 
Registers». The administrator guarantees access to information on issued agricultural receipts, which remain unfulfilled at the time of application. The registrar shall be entitled to provide information on issued agricultural receipts and their turnover history only with the consent of the debtor or creditor.

There are two types of agrarian receipts: commodity agrarian receipt and financial agrarian receipt. The difference between them is the determination of the subject of the obligation of a separate agrarian receipt: the commodity agrarian receipt is the subject of the obligation to supply the agreed type of agricultural products, and the financial receipt is the subject of the obligation agreed by the parties [3].

When issuing an agrarian receipt, the debtor agrees to deliver the future harvest (commodity agrarian receipt), or to pay the funds on the terms specified in the agrarian receipt (financial agrarian receipt), and such obligation is secured by the pledge of future harvest. agricultural products and the list of land on which it is to be grown [4].

For a proper notarization of the agrarian receipt, the prospective debtor must have the right of ownership of agricultural land or the right to use such land on legal grounds for the production of agricultural produce on which the crop is located, as well as the absence of other encumbrances on the harvest on such land [3] .

In general, the agrarian receipt credit mechanism involves at least two entities, but experience shows that quite often there can be three. Yes, the parties to the relationship may be:

1) agrarians (producers of agricultural products);

2) distributors (intermediaries who receive agrarian receipts from agrarians and act as the first creditors);

3) suppliers, financial institutions, traders (receive agrarian receipts from manufacturers or distributors and act as final creditors).

As a rule, distributors provide farmers with the products needed to grow products (seeds, fertilizers, pest control, etc.). For the distributor, the value usually comes from the money he wants to receive for the product that was provided to the farmer. In this case, the distributor may assign its right to a third party. Such a person becomes a trader who in the fall or at other times after the harvest will turn to the agrarian with the demand to deliver the goods.

Such a relationship scheme gives the farmer a significant advantage over the loan, since the obligation to deliver the goods or to pay the funds is in any case tied to the harvest. And in the case of a crop failure, the date of fulfillment of the obligations under the agreement with the creditor may be postponed to the next marketing year [1].

During the registration of the agricultural receipt, the notary verifies the fact of registration of the ownership or right to use the land plots, which gives additional guarantees of security during the processing and circulation of the agricultural receipt. Its performance should not depend on the fact of appeal or invalidity of the provisions of the secured contract. The compulsory execution of the agrarian receipt is carried out immediately by the execution of the notary's executive inscription [4].

Despite the possibility of effective enforcement of agrarian receipts, it should be remembered that such a receipt is first and foremost an agreement of the parties aimed at achieving a mutually beneficial goal, which cannot be achieved without 
respect for the rights of the other party and compliance with the obligations assumed.

Agrarian receipts have advantages for both agricultural producers and creditors. This form of lending allows to attract additional financial resources to agriculture, which testifies to the effectiveness of agricultural receipts as a tool for successful development of agricultural business in Ukraine.

\title{
References:
}

1. Лавріненко, І. (2019). Аграрна розписка як форма альтернативного кредитування. Юридична газета, (№7). Вилучено з http://yur-gazeta.com/dumka-eksperta/agrarna-rozpiskayak-forma-alternativnogo-kredituvannya.html.

2. Про аграрні розписки. (Закон України). 5479-VI. (2019). Вилучено 3 https://zakon.rada.gov.ua/laws/main/5479-17.

3. Зварун, Б. (2019). Аграрні розписки: поняття та особливості використання. Юридична газета, (28-29), 682-683. Вилучено з http://yur-gazeta.com/publications/practice/zemelneagrarne-pravo/agrarni-rozpiski-ponyattya-ta-osoblivosti-vikoristannya.html.

4. Скоропад, Б. (2019). Як працюють аграрні розписки. Юридична газета, (№32). Вилучено з http://yur-gazeta.com/publications/practice/inshe/yak-pracyuyut-agrarni-rozpiski.html

\section{ASSESSMENT OF THE EFFECTIVENESS OF EU COUNTRIES NATIONAL INNOVATION SYSTEMS}

\author{
Valeriia Gnidina \\ master's degree in Economics \\ Mariupol State University \\ UKRAINE
}

Nowadays, to be competitive in the international arena, national economies must constantly transform, using innovation and new technologies as a driving force. The national innovation system (NIS) allows quality control, regulate and effective manage of the country's innovation activities. Therefore, the formation of effective NIS is one of the urgent tasks of the EU countries. This task is being solved with varying intensity in the regions of Europe, which is associated with different economic and political prerequisites. That is why it becomes relevant to study the effectiveness of the EU countries NIS development for further finding possible ways to overcome the asymmetries of scientific, technical and innovative development in the context of European integration processes.

Thus, to assess the efficiency of the EU countries NIS functioning. the nonparametric method Data Envelopment Analysis was used, which evaluates the efficiency, which is defined as the quotient of the sum of all output parameters by the sum of all input factors. This method was developed in the $70-80^{\text {th }}$ of the XX century in the works of $A$. Charnes and others [1, pp. 429-444]. The DEA is used to measure the effectiveness of decision-making units. These may be countries or 
other entities whose relative effectiveness needs to be calculated. According to the DEA, an object can be considered effective if no other object (s) can produce a more innovative result with a given amount of innovative resources.

Within the DEA, effectiveness evaluation can be viewed from the point of view of maximizing results at a fixed volume of resources or, conversely, from the point of view of minimizing the resources used at a fixed volume of output. The first case of the DEA problem corresponds to the specification of the output-oriented DEA model, the second case - input-oriented DEA.

So, using the data DEA method, it can build an efficiency boundary. It has the form of a certain convex hull in the space of input and output variables. Accordingly, based on the name of the method, this efficiency boundary wraps around the points corresponding to the studied objects in multidimensional space [1, pp. 423-424]. The efficiency boundary is used as a reference point, where the level of efficiency of each object will be as the distance from it to the boundary in the space of inputs and outputs.

There are two basic models of the nonparametric DEA method. The first model built by Charnes, Cooper and Rhodes, which assumed a constant scale effect on production, was called Constant Retuns to Scale (CRS) [1, pp. 425-426]. For this model, the length of the segment from the test point to the efficiency boundary is the amount by which input costs can be proportionally reduced without reducing the volume of output.

There is also another model where variable returns to scale (VRS) are assumed. It was created by Benker, Charnes and Cooper in 1984. Here, one country in the VRS model cannot be countered by the ratios or shares of other countries, but only by weighted sums, as long as the sum of the estimated factors is 1 . Such models make it possible to determine the technical inefficiency of an individual country, which consists in a proportional decrease in the values of input parameters with a constant level of output.

That is, one of the advantages of the DEA is the ability to assess the effectiveness as a whole, as a result of the influence of many factors on the output indicator. This approach differs from the accepted ones associated with the formation of an index based on weighted indicators. Also, the main feature is that the method focuses on identifying examples of so-called best practice, and not on some averaged trends, such as regression analysis.

It should be noted that for the analysis of the EU NIS development efficiency (for 2016-2018) using the DEA method, it was selected 5 indicators of innovative development, which in a complex characterize the modern functioning of the NIS. The input indicators, i.e. innovative resources, included 4 indicators: 1 . volumes of financing of research activities (thousands of dollars) [2]; 2. number of employees involved in $\mathrm{R} \& \mathrm{~d}$ (persons); 3. number of patent applications [3]; 4. trademark applications per 1 billion GDP (in PPS). As an output indicator of efficiency was selected as high-tech exports in million \$ USA.

It should be noted that in the practice of estimation, as a rule, the specification of the source model (output-oriented) is used, focused on maximizing the output indicator. The calculations results of the output-oriented model are shown in fig. 1. 


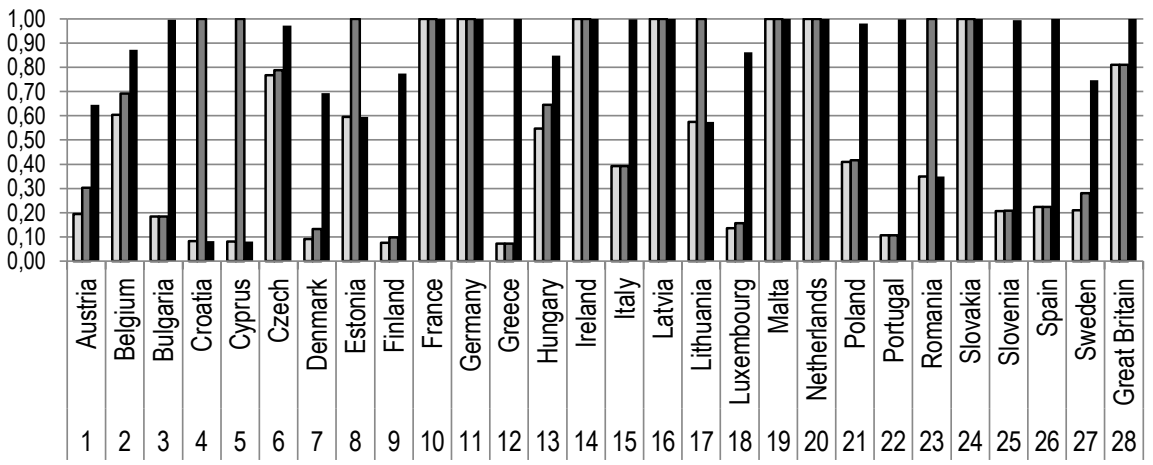

口Effectiveness of the model CRS $\quad$ Effectiveness of the model VRS $\quad$ Scale efficiency (CRS/VRS)

Fig. 1. Results of efficiency calculation of EU countries NIS by the output -oriented model DEA

Source: Author's own calculations

Note that a country with an indicator of 1 or $100 \%$ is considered effective, that is, «reference» for others and, in our opinion, it can be attributed to the so-called «effective pole». But it should be noted that the proportion of countries that formed the «effective pole» («reference» countries) differs in terms of constant and variable scale effects, and amounted to 25,0\% (7 countries) and 42,9\% (12 countries), respectively. In terms of scale efficiency (CRS to VRS ratio), 14 countries (exactly $50 \%$ of the EU) are effective.

The constant return to scale (CRS) model is more rigid and imposes severe additional constraints. The average innovation efficiency calculated on this model, which is 0.49 , is significantly lower than the calculated variable economies of scale (VRS), which was 0.63 . The scale efficiency, which describes the ratio of efficiency calculated from constant returns to scale to efficiency from variables, is equil averages 0,829 for EU countries.

The CRS model calculates efficiency, with the acceptance of the fact that a proportional increase in the number of all factors of production used leads to an increase in output in the same proportion [4]. Thus, in terms of constant returns to scale, 15 countries (from Poland with a CRS efficiency of 0,41 or $41 \%$ and ending with Greece with 0,07 or $7 \%$ ) were ineffective (less than 0,5 ). It should also be noted that the «non-reference» objects with the formation of high-tech exports included innovative leaders in GII, such as Sweden $(0,21$ or $21 \%)$, Denmark $(0,09$ or $9 \%)$ and Finland $(0,08$ or $8 \%)$, which could produce more innovative output with available resources.

According to the VRS model, which helps to evaluate efficiency regardless of whether there is a proportional change in input and output variables. This method involves both increasing and decreasing returns to scale. The analysis shows that Cyprus, Lithuania, Estonia, Romania and Croatia also entered the «effective poles» 
with a score of 1 or $100 \%$. In this model, the «non-reference» objects included innovative leaders in GII, such as Sweden (a higher figure in this model $-0,28$ or $28 \%)$, Denmark $(0,13$ or $13 \%)$ and Finland $(0,10$ or $10 \%)$, which could, with their available resources, produce more actual innovative output. According to the VRS rating, Greece also ranks last $(0,07$ or $7 \%)$, which indicates that it has the weakest NIS among EU member states.

It should also be noted that there are countries that have 1 or $100 \%$ on all three performance indicators, that is, they are "reference" for others. They are 7 countries, among which Gll innovation leaders are Germany, France, the Netherlands and Ireland; and catching up EU innovators are Malta, Slovakia and Latvia. That is, these countries make the most effective use of their input innovative resources and thanks to them produce the highest possible high-tech exports.

Thus, as a result of the analysis, it became clear that the overall leadership in the field of innovation is not a guarantee of high efficiency in the production of hightech exports. Having studied the experience of the «effective pole» countries, EU countries can develop a set of measures to improve the efficiency of their NIS, which will allow them to be more competitive on the world stage.

\title{
References:
}

1. Charnes, A., Cooper, W. \& Rhodes, L. (1978). Measuring the Efficiency of Decision Making Units. European Journal of Operational Research. №2. Pp. 429-444.

2. European Innovation Scoreboard (2019).

http://ec.europa.eu/growth/industry/innovation/facts-figures/scoreboards_en

Retrieved from 06.11.2019).

3. UIS Statistics. UNESCO Institute for Statistics (UIS). Retrieved from http://data.uis.unesco.org/

4. Coelli, T.J. (1996). A Guide to DEAP Version 2.1: A Data Envelopment Analysis (Computer) Program. CEPA Working Paper 96/08. University of New England, Armidale.

\section{DIAGNOSIS OF METHODS OF ESTIMATION OF EFFICIENCY OF TRANSPORT AND LOGISTICS SYSTEMS OF METALLURGICAL ENTERPRISES}

\author{
Elena Amelnitskaya \\ Ph.D., Associate Professor \\ Prizovsky State Technical University \\ UKRAINE
}

The study of the essence, components and varieties of methods of estimating the efficiency of transport and logistics systems has received enough attention of such leading specialists in the field of logistics as as A. Kalchenko, E. Krykavsky, T. Kolodizieva, V. Perebinis, O. Sokolov, O. Dorokhovsky, B. Syzdikbaeva and others [1-8]. In the economic literature (both foreign and domestic) there is no consensus on the set of indicators for assessing the efficiency of transport and logistics systems of enterprises. 
The purpose of the article is to analyze the existing methods of evaluating the efficiency of transport and logistics systems of a metallurgical enterprise.

The concept of "logistics system" comes from the general "system" and is one of the basic in logistics, implementing a systematic approach. However, there is no universally accepted definition of this concept in modern scientific literature. According to [1], a logistics system is an adaptive feedback system that performs certain logistic functions (operations), consists of subsystems and has developed internal system connections and connections with the external environment. In [2], the author under the logistic system understands the specially organized integration of logistical elements (links) within a certain economic system to optimize the processes of material flow transformation. According to [3], the logistics system is a complex system consisting of a set of elements, the so-called links of the logistics system, between which certain functional relationships and relationships are established. In [4], a logistic system means an adapted (self-adjusting and selforganizing) system with feedback, which performs logistic functions and logistic operations and consists, as a rule, of several systems and has developed links with the external environment.

The main purpose of the transport and logistics system is to provide high quality customer service in the field of transportation and logistics.

The analysis of the literary sources showed that the formulation of the concept "transport and logistics system" is found only in a small number of works by leading experts in the field of transport and logistics. More often, they consider the transport system or logistics system separately. If the information sources contain the concept of "transport and logistics system", then more often it is understood as the logistics system.

In [5] the author defines the transport and logistics system is defined as a set of objects and subjects of transport and logistics infrastructure together with material, financial and information flows between them, which performs the functions of transportation, storage, distribution of goods, as well as information and legal support of commodity flows. In [6], the transport and logistics system is considered as an integrated set of transport and logistics entities and objects of transport and logistics infrastructure that interact with each other to optimize door-to-door movement of goods at minimal cost at the most favorable conditions. .

Dorokhovskiy O.M. [7] investigates the transport-logistic system in the context of the region and defines it as a set of functional and providing subsystems, consisting of numerous interacting and interdependent elements - links of the state transport-distribution network, integrated by the commodity-material flow, general conducting business in line with the strategy of socio-economic development of the region and Ukraine. The definitions under consideration look on the transport and logistics system as a set of objects and entities that perform the functions of transportation and logistics through interaction. However, they do not take into account the client-oriented approach, the interests of all stakeholders, as well as the concept of the system that needs to be considered in terms of the systematic approach. 
In [8], the transport and logistics system is considered as a multilevel and multifunctional system consisting of micro, meso and macro levels, which not only satisfies the needs for transport and logistics services, but also enhances the competitiveness of the region. This definition contains the concept of the system and the purpose of its operation, but does not focus on all stakeholders.

Transportation and logistics systems are characterized by certain specific goals of operation:

1) financial goals, which are expressed in the form of profit for efficiency;

2) production and technical goals, which are expressed by the overall productivity and productivity of individual units, minimizing certain periods of time in the production process;

3) technical efficiency, technical parameters, resource intensity of the enterprise [9].

Modern transport and logistics systems are complex management objects, characterized by a large number of technological connections between individual subsystems, many factors of influence. The complexity of technology Modern transport and logistics systems are complex management objects, characterized by a large number of technological connections between individual subsystems, many factors of influence. The complexity of transport and logistics system technology, the undetermined nature of inbound flows, the large number of restrictions and factors stipulated by the technological regulations determine the effectiveness of its functioning as an object of management. The creation of an efficient transport and logistics system is directly influenced by certain factors (Fig. 1).

At present, there is no consensus on the criteria for evaluating the performance of the logistics system, including transportation and logistics, and the efficiency of customer service.

According to [2], evaluating the efficiency of logistics systems involves determining the performance level of an integrated supply chain through qualitative and quantitative characteristics.

The qualitative characteristics include:

- customer satisfaction (level of customer satisfaction);

- elasticity (level of response of the supply chain to changes in demand);

- the level of integration of the movement of information and raw materials;

- effective risk management (degree of risk minimization);

- supplier efficiency (percentage of timely deliveries and quality of deliveries).

Quantitative characteristics include:

- productivity (maximization of productivity, maximization of attraction of means);

- costs (cost reduction);

- response capabilities (level of orders completed, frequency of non-urgent deliveries, time of order realization, reduction of duplication of functions, frequency of returns, profitability of logistics costs);

- maximizing sales;

- profit maximization;

- return on investment. 


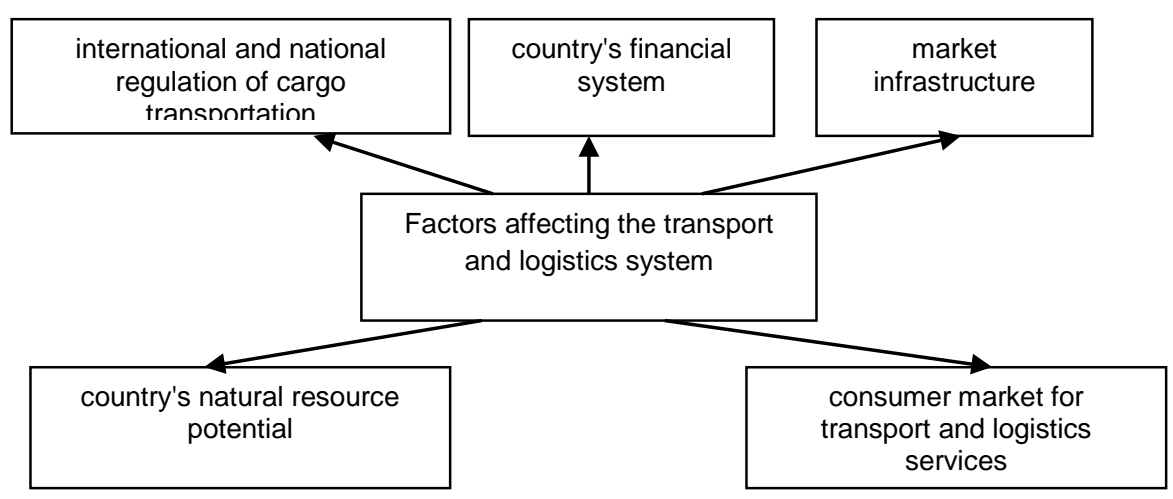

Fig. 1. Factors affecting transport and logistics infrastructure [10]

Bowersox D. and Kloss D. propose to measure the efficiency of the logistics system to identify two groups of logistics indicators: internal and external. The internal indicators are divided into the following categories: costs, customer service, productivity, asset management, quality. These indicators should reflect the efficiency of the main logistics operations of internal processes. The need for external indicators is seen in the identification and realization of consumer expectations as the main benchmark of the logistics system [11].

Scientists in [3] consider as the main tools of analysis of efficiency of logistic processes methods of economic analysis which allow:

- to evaluate the actual state of logistical phenomena and processes;

- to set and identify sources and causes of problems;

- to clarify short-term forecasts of the development of specific phenomena and processes;

- to formulate conclusions and proposals that will increase the efficiency of management.

Economic analysis of logistic processes is proposed to be carried out in three thematic blocks: analysis of material and information processes (analysis of the procurement process, inventory analysis, analysis of warehouse processes, analysis of sales processes); management analysis of logistic processes (own production or purchase, choice of sources of procurement, efficiency of transport service, efficiency of warehouse investments, choice of distribution channels); logistic cost analysis (promotion cost analysis, inventory cost analysis, cost information analysis).

Specialist [12], as the most important indicator of performance evaluation of logistics systems, offers a profit that can reflect the results of all logistics activities. $\mathrm{He}$ considers the efficiency of the logistics system itself as an indicator (or system of indicators) that characterize the level of quality of functioning of the system at a given level of total logistics costs. It must define: the boundaries of the logistics system, its links, the main resources used, the main products of the logistics system, the expected or desired results, the performance criteria of the system, the process of evaluation, feedback regulation and improvement planning. 
The most widespread are the evaluation criteria such as: costs, consumer satisfaction / quality, time and assets. Factors or indicators of their evaluation are given in Table. 1.

Various experts and scientists use many indicators to evaluate the level of efficiency of the transport and logistics system, which is appropriate to combine into three groups:

- supplier-to-consumer communication factor (CPS) - reflects the effectiveness of a given consumer's communication with a particular supplier. It is calculated as the ratio of the amount of resources (raw materials, etc.) received to the consumer during the reporting period from the supplier to the total amount of resources received to the consumer;

Table 1

\section{Factors (indicators) for evaluating the most common criteria for evaluating the efficiency of logistics systems [13]}

\begin{tabular}{|l|l|}
\hline $\begin{array}{c}\text { Performance } \\
\text { evaluation } \\
\text { criterion }\end{array}$ & \multicolumn{1}{c|}{ Assessment factor (indicator) } \\
\hline Costs & $\begin{array}{l}\text { They reflect the total monetary amount of expenses, the monetary amount per } \\
\text { unit of production, or the share of sales. } \\
\text { Seek to reduce their level }\end{array}$ \\
\hline $\begin{array}{l}\text { Consumer } \\
\text { satisfaction / } \\
\text { quality }\end{array}$ & $\begin{array}{l}\text { It is estimated by the length of the functional cycle, the level of perfection of } \\
\text { order fulfillment and the ability of the enterprise to respond to the claims made } \\
\text { by the consumer. Important indicators are delivery on time, warranty costs, } \\
\text { response time to customers' claims and satisfaction }\end{array}$ \\
\hline Time & $\begin{array}{l}\text { It is a measure of the ability of an enterprise to respond quickly to consumer } \\
\text { claims. The key indicators of the duration of order fulfillment are: duration of } \\
\text { production cycle, duration of entry } \\
\text { appropriate adjustments to operational plans; the duration of the production } \\
\text { plan and the degree of compliance with the production plans }\end{array}$ \\
\hline Assets & $\begin{array}{l}\text { The subject of their evaluation is the efficiency of the use of the capital invested } \\
\text { in structures and equipment, as well as the working capital. } \\
\text { Key indicators of asset utilization are accuracy of forecasts, stock aging, } \\
\text { capacity utilization and more }\end{array}$ \\
\hline
\end{tabular}

- coefficient of readiness for delivery (CGP) - is defined as the ratio (in percentage) of the number of orders executed by a given enterprise to the number of orders received at a given enterprise or as the ratio of the volume of products supplied to the volume of products ordered by consumers. Increasing the readiness for delivery to an approaching unit value is in some cases economically inappropriate for the supplier because the costs are growing faster than revenues;

- indicator of the number of links in the logistics system - the average number of trade units (intermediaries) through which the material flow from the producer to the end consumer of resources (finished products) passes.

2. Performance indicators of the logistics system from the point of view of the consumer: quality of service; service price. 
Also used is a summary indicator that characterizes the ability of the company to achieve full customer satisfaction, it is called "perfect order". This indicator characterizes how evenly and uninterruptedly the order is executed at all stages, the organization of logistic activity should meet such standards [14]:

- full delivery of all goods for all ordered items;

- delivery within the required time to the consumer with a tolerance of 1 day:

- complete and accurate order documentation;

- perfect compliance with the agreed delivery conditions (installation, equipment, absence of damage).

3. Performance indicator of the logistics system from the point of view of its members (supplier, intermediary, manufacturer). In this case, the criterion for the effectiveness of the logistics system is to maximize profit per unit of logistics costs, provided the required quality of service.

The level of development (excellence) of logistics systems can be estimated by the degree of integration of logistics processes, namely [15]:

- fragmentary level (integration at the level of individual logistics processes, functions);

- functional (integration covers separate functional areas);

- systemic (integration covers the logistic activity of the enterprise);

- integration at the supply chain level (with the coverage of all members of the logistics network).

Due to the specific features of metallurgical production processes, a transport and logistics system containing in-plant transport (rail, car, special transport for technological transportation) and warehousing plays a crucial role in production, directly affecting the progress of the production program and the cost of production.

Features of the metallurgical enterprise due to the following characteristics:

- the presence of heavy loads of massive and heavy loads (iron and manganese ore, agglomerate, iron scrap, limestone, coal, refractories, ingots, rolled metal);

- large and constant flows of specific cargo;

- long distances of transportation;

- the variety of transport modes used;

- scattering and a large number of shops and warehouses, which are characterized by the presence of hoisting-and-transport devices and auxiliary equipment for processing and moving of tare-piece and bulk cargo.

The main processes in the transport and logistics system of a metallurgical enterprise are:

- transportation processes in special rolling stock of hot agglomerate, liquid iron, steel and slag;

- processes of transportation according to contact schedules;

- processes of transportation of goods coming from the junction station;

- processes of irregular transportation on orders of shops and in cooperation with other enterprises.

Each process depends on certain parameters of the transport and logistics system and is connected with other processes.

From the standpoint of a systematic approach, the warehouse complex of a metallurgical enterprise is a top-level logistics system. In this case, it is 
characterized by the input and output material flows of vehicles and goods and the accompanying information (documentary), financial, etc. flows.

This system is micrologistic, transport and cargo management is fully relevant to the industrial transport functions of the enterprise. With other systems (suppliers, consumers, transport infrastructure, ports, interchanges, etc.), it exchanges management impacts that are generated through the processing and analysis of information flows.

The micrologistic system of transportation of a metallurgical enterprise includes a set of divisions of the enterprise and technical means, technological processes and operations, controlling influences on the transport process; material flows (transport and freight flows), information (documentary) and financial flows.

The first-rank subsystems of the micrologistic transport and logistics system of a metallurgical enterprise are the directorates of transport and logistics, production, supply and sale; departments that control the quality of raw materials and finished products; accept inbound cargo flows, etc. Each subsystem performs its own functions, defining the limits of its independence, but they are all integrated into a single system and perform purposeful actions to ensure its main task - the efficient execution of cargo delivery processes and related technological processes.

The subsystems of the second rank of the micrologistic transport-logistic system of a metallurgical enterprise are the operation shop, cargo service, railway stations (districts), track maintenance and repair service, STSB, locomotive and wagon repair depots, cargo points of production units and units.

Elements of the micrologistic transport-logistic system of a metallurgical enterprise are races, receiving and starting and sorting parks (tracks), points of equipment, maintenance and repair of rolling stock, devices of restoration of bulk flow of cargoes, weights, cargo fronts and points of cleaning of weights.

Therefore, the following criteria for evaluation of the efficiency of the transport and logistics system of a metallurgical enterprise were the most widely used:

- costs for creating and maintaining a logistics system;

- customer satisfaction with the quality of logistics services;

- time of logistics operations;

- the value of assets created through logistic management approaches.

\section{References:}

1. Кальченко, А.Г. (2012). Логістика. К.: КНЕУ.

2. Крикавський, Є. В., Чорнописька Н. В. (2009). Логістичні системи. Львів: Вид-во Нац. унту «Львівська політехніка».

3. Колодізєва, Т. О., Руденко Г. Р. (2012). Методичне забезпечення оцінки ефективності логістичної діяльності підприємств. Харків: Вид. ХНЕУ.

4. Перебийніс, В. І., Перебійніс, О.В.(2014). Транспортно-логістичні системи. Полтава: РВВ ПУСКУ.

5. Транспортно-логистические системы, сущность и цели ффункиионирования. (2014). Вилучено 3 http://pandia.ru/text/77/318/11726.php

6. Соколова, О. Є. (2016). Теоретико-методологічні основи формування транспортнологістичної системи України.

Вилучено http://ecobio.nau.edu.ua/index.php/PPEl/article/viewfile/182/173. 
7. Дороховський, О. М. (2013). Формування та функціонування регіональних транспортнологістичних систем: теорія, методологія, практика (дис. ... д-ра екон. наук). Херсон. Україна.

8. Сыздыкбаева, Б. У. (2010). Методология фрормирования и развития интегрированной транспортно-логистической системы Казахстана (автореф. дис. ... д-ра экон. наук). Туркестан. Вилучено з http://dislib.ru/ekonomika/24633-1-metodologiya-formirovaniya-razvitiyaintegrirovannoy-transportno-logisticheskoy-sistemi-kazahstana.php

9. Гурч, Л.М. (2008). Логістика. Київ: ДП «Видавничий дім», «Персонал».

10. Брагінський, В. В. (2011). Розвиток транспортно-логістичної системи як форма реалізації транзитного потенціалу України. Державне управління: теорія і практика, (2). Вилучено з http://www.academy.gov.ua/ej/ej14/index.htm

11. Бауэрокс, Дональд Дж., Клосс \& Дейвид Дж. (2012). Логистика: интегрированная цепь поставок (пер. с англ.). М.: ЗАО «Олімп-Бизнес».

12. Хвищун, Н. В. (2016). Логістичні складові підвищення конкурентоспроможності підприємства. Логістика: теорія та практика, (1), 126-134.

13. Чорнописька, Н.В. (2015). Методичні підходи до оцінювання логістичної діяльності підприємства. Вісник НУ «Львівська політехніка», (608), 265-271.

14. Маркіна, І.А. (2013). Методологічні питання ефективності управління. Фінанси України, (6), 24-32.

15. Карвовський, Я. І., Блонський, К. М. (2016). Логістика в управлінні стосунками з клієнтами. Вісн. нац. ун-ту «Львів. Політехніка». Логістика, (552), 35-39.

\title{
DIE EIGENSCHAFTEN EXISTIERENDER MARKETING- STRATEGIEN DES UNTERNEHMENS
}

\author{
Mariia Amelnytska \\ Nationale Technische Universität Donezk \\ Wissenschaftlicher Berater: Olga Popova \\ Doktor der Wirtschaftswissenschaften, Professor \\ Nationale Technische Universität Donezk
}

UKRAINE

Die Integration der Ukraine in den Weltwirtschaftsraum erfordert die Stärkung der strategischen Ausrichtung der Unternehmenstätigkeit. Ein äußerst wichtiger Platz in der strategischen Tätigkeit des Unternehmens ist seine Marketingstrategie, die die marktstrategischen Ausrichtungen bildet.

Das Studium des Wesens, der Bestandteile und der Varianten von Marketingstrategien wurde von führenden Experten auf dem Gebiet des Marketings wie I. Ansoff, M. MacDonald, F. Kotler, E. Romat, S. Garkavenko, N. Kudenko, O. Belovodskaya und anderen genügend beachtet [1 - 8]. Die theoretische Grundlage der Unternehmensmarketingstrategie ist jedoch bis heute schwach. In der Wirtschaftsliteratur (sowohl im In- als auch im Ausland) gibt es keinen Konsens über Art und Inhalt der Unternehmensmarketingstrategie. 
Ziel des Artikels ist es, das Wesen und die Vielfalt bestehender Marketingstrategien des Unternehmens zu analysieren.

Es gibt viele Ansichten zur Definition einer Marketingstrategie. Mehr

Die relevanten Konzepte sind:

- Marketingstrategie ist ein System organisatorischer, technischer und finanzieller Maßnahmen zur Intensivierung der Produktion und des Absatzes von Produkten, zur Steigerung ihrer Wettbewerbsfähigkeit und zur aktiven Beeinflussung von Angebot und Nachfrage. Eine Marketingstrategie beinhaltet die Kontrolle der Produktion und des Marktes, um die Marktpreise auf einem Niveau zu halten, das optimale Renditen liefert. Die Vermarktungsstrategie wird im Rahmen des Maßnahmenprogramms zur Verbesserung der Produktion und des Verkaufs von Waren umgesetzt, um hohe und nachhaltige Gewinne sicherzustellen.

- Marketingstrategie ist die Richtung (Vektor) der Maßnahmen des Unternehmens zur Schaffung seiner Zielmarktpositionen [1];

- Marketingstrategien sind das Mittel zur Erreichung der Marketingziele für den Marketing-Mix [2].

Marketingstrategie ist eine grundlegende mittel- und langfristige Entscheidung mit geeigneten Methoden und Mitteln, die die Benchmarks und direkten individuellen Marketingmaßnahmen definiert, um die Ziele zu erreichen, die die Elemente des Marketingkomplexes (Produkt, Preis, Standort und Werbung) abdecken. Dies sind globale Aktivitäten, die durch die Planung von Marketingaktivitäten festgelegt werden müssen [3].

Nach F. Kotler ist eine Marketingstrategie ein logisches Schema von Marketingaktivitäten, mit denen ein Unternehmen seine Marketingaufgaben erfüllen möchte. Es besteht aus getrennten Strategien für Zielmärkte, Positionierung, Marketingkomplex und die Höhe der Ausgaben für Marketingaktivitäten. In der Marketingstrategie sollten die Marktsegmente angegeben werden, auf die sich das Unternehmen konzentrieren möchte [4].

E. Romat betrachtet die Marketingstrategie als "ein umfangreiches Aktionsprogramm des Unternehmens, das die Entwicklung von Zielmärkten (Segmenten), den Marketingkomplex, das Marketingbudget und die wichtigsten Zeitaspekte des Programms umfasst" [5]. S. Garkavenko bedeutet unter dem Begriff "Marketingstrategie" "einen umfassenden umfassenden Plan zur Erreichung von Marketingzielen" [6], M. Dmytruk [7] "ein Szenario von Maßnahmen zur Erreichung von Marketingzielen" und N. Kudenko [8] "Vektor (Richtung) die Maßnahmen des Unternehmens zur Schaffung seiner Zielmarktpositionen".

Je genauer die Marketingprognosen und -berechnungen sind, je näher sie am tatsächlichen Ergebnis sind, desto größer ist der Erfolg des Unternehmens. Zu diesem Zweck ist es in erster Linie erforderlich, die Methodik und Technologie der Marktforschung sowie die Quellen, Arten und Mengen der Informationen richtig auszuwählen. Markt und Zielsegmente richtig auswählen (unter Berücksichtigung der Entwicklungsperspektiven); die Bedürfnisse und Vorlieben der Käufer vorhersagen, die Nachfragegenerierung berücksichtigen.

Marketingstrategien werden nach verschiedenen Merkmalen klassifiziert. In Abb. 1 zeigt eine Klassifizierung der Marketingstrategien. 


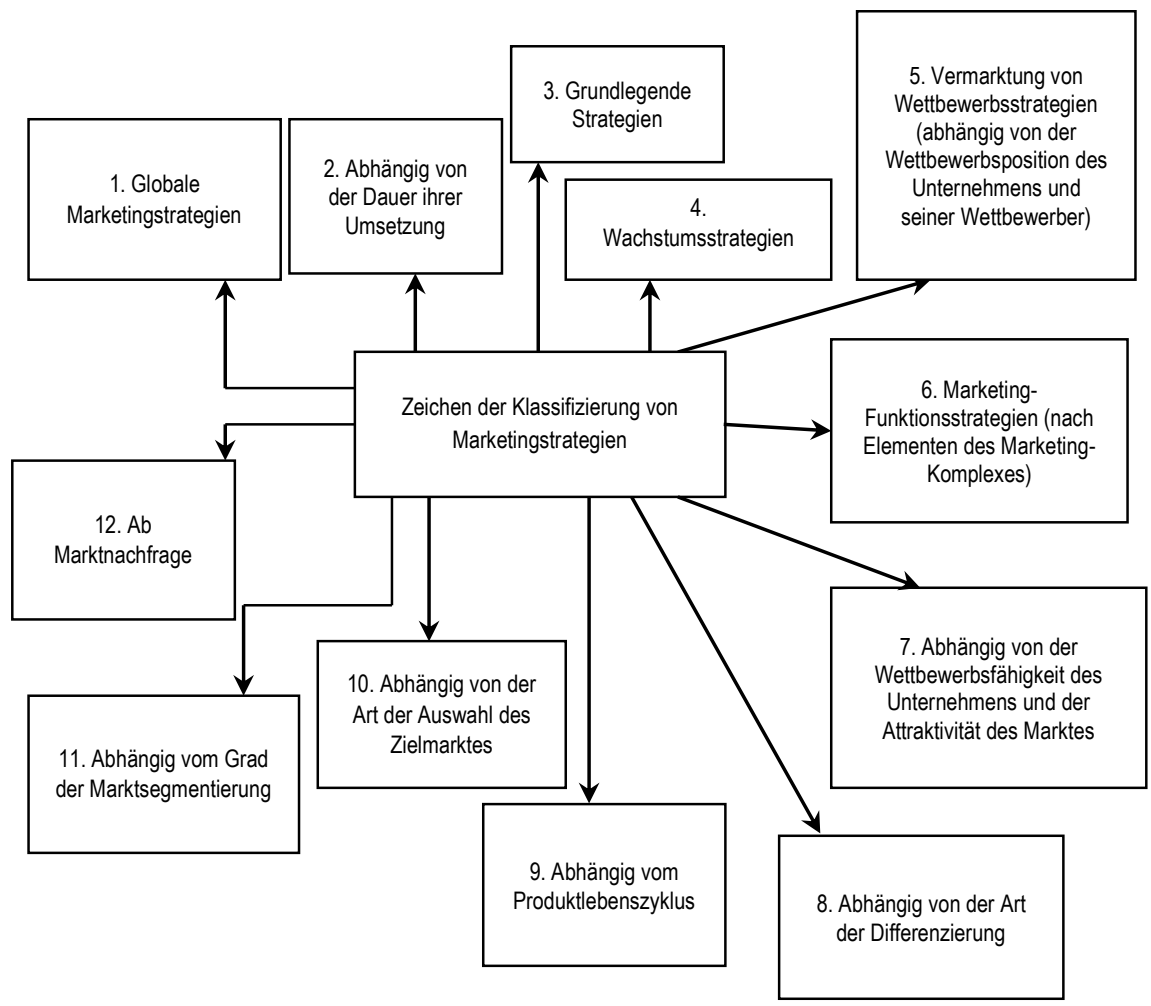

Abb. 1. Klassifizierung von Marketingstrategien [9]

Es gibt fünf globale Marketingstrategien, die die Hauptentscheidungen für die Wahl der Entwicklungsrichtung des Unternehmens bestimmen:

- die Internationalisierungsstrategie beinhaltet die Erschließung neuer Märkte.

- die Diversifizierungsstrategie - Entwicklung der Produktion neuer Güter (einschließlich nicht mit den Hauptaktivitäten verbunden);

- die Segmentierungsstrategie - Produktion einer breiten Palette von Produkten für verschiedene Verbrauchergruppen;

- die Globalisierungsstrategie - Standardisierung von Produkten auf der Grundlage der Bestimmung der allgemeinen Merkmale von Märkten, die nicht von den Merkmalen der Länder abhängen;

- die Kooperationsstrategie - gegenseitig vorteilhafte Zusammenarbeit mit anderen Unternehmen (Schaffung von Einkaufs-, Forschungs-, Werbefirmen, gemeinsamen Marken).

Abhängig vom Zeitpunkt der Marketingstrategien werden langfristige, mittelfristige und kurzfristige Strategien unterschieden.

Als Grundstrategien gelten:

- die Preisführungsstrategien; 
- die Differenzierungsstrategien;

- die Fokussierungsstrategien (Konzentration).

Marketing-Wettbewerbsstrategien sind differenziert. Die Klassifizierung der Marketingstrategien ist in der Tabelle dargestellt 1.

Tabelle 1

Klassifizierung von Marketing-Wettbewerbsstrategien

\begin{tabular}{|c|c|c|}
\hline $\begin{array}{l}\text { Autor der } \\
\text { Klassifikation }\end{array}$ & $\begin{array}{l}\text { Klassifizierung } \\
\text { Zeichen }\end{array}$ & $\begin{array}{l}\text { Arten von Marketing- } \\
\text { Wettbewerbsstrategien }\end{array}$ \\
\hline \multirow[t]{5}{*}{ A. Little } & \multirow{5}{*}{$\begin{array}{l}\text { Konkurrenten der Position } \\
\text { eines Unternehmens und } \\
\text { ihrer } \\
\text { Verbesserungsmöglichkeiten }\end{array}$} & Führungsstrategien \\
\hline & & $\begin{array}{l}\text { Strategien von Unternehmen mit einer } \\
\text { starken Position }\end{array}$ \\
\hline & & $\begin{array}{l}\text { Strategien für Unternehmen, die } \\
\text { günstig sind }\end{array}$ \\
\hline & & $\begin{array}{l}\text { Strategien von Unternehmen, die eine } \\
\text { zufriedenstellende Position innehaben }\end{array}$ \\
\hline & & $\begin{array}{l}\text { Strategien von Unternehmen, die } \\
\text { unbefriedigend sind }\end{array}$ \\
\hline \multirow[t]{3}{*}{ M. Porter } & \multirow{3}{*}{$\begin{array}{l}\text { Wettbewerbsvorteil des } \\
\text { Unternehmens auf dem } \\
\text { Markt }\end{array}$} & Preisführerschaftsstrategie \\
\hline & & Differenzierungsstrategie \\
\hline & & Konzentrationsstrategie \\
\hline \multirow[t]{4}{*}{ F. Kotlers } & \multirow{4}{*}{$\begin{array}{l}\text { Wettbewerbspositionen des } \\
\text { Unternehmens und seine } \\
\text { Vermarktungsrichtungen }\end{array}$} & Marktführer-Strategien \\
\hline & & Challenger-Strategien \\
\hline & & Follower-Strategien \\
\hline & & Nischenstrategien \\
\hline
\end{tabular}

Der amerikanische Vermarkter Arthur Little beispielsweise unterscheidet Marketing-Wettbewerbsstrategien in Abhängigkeit von der Wettbewerbsposition des Unternehmens und seiner Fähigkeit, diese Positionen zu verbessern.

Eine führende (marktbeherrschende) Stellung bedeutet die starke Wettbewerbsposition eines Unternehmens, seine große Fähigkeit, strategische Entwicklungsrichtungen zu wählen und seine Fähigkeit, die Marktaktivität anderer Unternehmen zu beeinflussen.

Eine starke Position ermöglicht es dem Unternehmen, unabhängige Marktaktivitäten durchzuführen. Dies bedeutet nicht, dass das Unternehmen eine unabhängige Marketingstrategie formulieren kann, ohne seine Marktposition zu 
verschlechtern, sondern dass das Wettbewerbsverhalten des Marktführers berücksichtigt wird.

Eine günstige Position bedeutet, dass das Unternehmen einen gewissen Wettbewerbsvorteil hat, den es für seine strategischen Aktivitäten nutzt. Am häufigsten wird diese Position von Unternehmen besetzt, die eine Nischenstrategie verfolgen. Eine günstige Position impliziert, dass das Unternehmen überdurchschnittliche Marktpositionen einnimmt und Verbesserungsmöglichkeiten hat.

Eine zufriedenstellende Position impliziert, dass das Unternehmen günstige Möglichkeiten hat, seine Tätigkeit auf einem bestimmten Markt fortzusetzen, aber seine Fähigkeit, seine Marktposition zu behaupten und zu verbessern, ist unterdurchschnittlich, und daher kann das führende Unternehmen, falls gewünscht, seine Position zerstören.

Eine unbefriedigende Position bedeutet eine unbefriedigende Wettbewerbsposition des Unternehmens und das Fehlen von Verbesserungsmöglichkeiten. Es kennzeichnet die schwache Marktlage des Unternehmens. das Vorhandensein einer Wettbewerbsanfälligkeit und das Fehlen von Möglichkeiten für das Unternehmen, die bestehende Situation zu verbessern.

M. Porter klassifiziert die Wettbewerbsstrategien des Unternehmens anhand des Wettbewerbsvorteils, der es dem Unternehmen ermöglicht, im Wettbewerb erfolgreich $\mathrm{zu}$ sein. Laut $M$. Porter sind die Hauptvarianten der Wettbewerbsstrategien des Unternehmens: die Preisführerschaftsstrategie, die Differenzierungsstrategie, die Konzentrationsstrategie.

F. Kotlers Ansatz zur Verbreitung von Marketing-Wettbewerbsstrategien des Unternehmens beinhaltet die Berücksichtigung des Unternehmens hinsichtlich seiner Wettbewerbsposition und seiner Marketing-Trends. MarketingWettbewerbsstrategien reproduzieren die Beziehungen, Handlungen und Gegenmaßnahmen von Unternehmen auf dem Markt,

Nach diesem Ansatz unterscheidet F. Kotler vier Arten von MarketingWettbewerbsstrategien: die Marketingstrategien des Marktführers, die Marketingstrategien des Challengers, die Marketingstrategien des Nachfolgers, die Marketingstrategien der Nische.

Marktführer sind diejenigen Unternehmen, die in einem bestimmten Markt den größten Marktanteil haben.

Herausforderer sind Unternehmen, die zweite oder dritte Marktpositionen einnehmen, sich rasch entwickeln und darauf abzielen, ihren Marktanteil zu erhöhen.

Die Anhänger sind erfolgreiche Unternehmen auf dem Markt, deren MarketingFokus nicht auf der Erlangung der Marktführerschaft (im Gegensatz zu Challengers) liegt, sondern auf der Erhaltung und dem Schutz ihrer Marktanteile.

Nischen sind Unternehmen, die kleine Marktsegmente bedienen, die von großen Unternehmen unbeaufsichtigt bleiben (mithilfe einer Nischenstrategie).

Wenn wir die Kapazität eines bestimmten Marktes für 100\% halten, wird der Anteil der Marktführer, Herausforderer, Anhänger und Nischen wie folgt verteilt: Marktführer besetzen $40 \%$ des Marktes, Herausforderer - $30 \%$, Anhänger - $20 \%$, Nischen - 10\%.

Marketing-Wachstumsstrategien. Wenn ein Unternehmen über eine stabile Marktposition und eine stabile Entwicklung verfügt und Umsatz, Gewinn und Umfang der Geschäftstätigkeit weiter steigern möchte, hat es drei Möglichkeiten: 
- die Intensivierung bestehender Chancen und Ressourcen des Unternehmens - intensives Wachstum;

- die Zusammenarbeit mit anderen Unternehmen - integratives Wachstum;

- der Zugang zu anderen Geschäftsbereichen, die nicht mit der Haupttätigkeit des Unternehmens zusammenhängen - Diversifizierungswachstum.

Marketing-Wachstumsstrategien sind in Tabelle 2 zusammengefasst.

Die Wahl einer intensiven Wachstumsstrategie sollte auf den folgenden Fähigkeiten des Unternehmens beruhen:

- die Steigerung des Marktanteils und des Absatzvolumens bestimmter Waren auf bestehenden Märkten; wenn ja, tiefes Eindringen;

- die Suche nach neuen Märkten für die bestehenden Produkte des Unternehmens; falls verfügbar - Marktentwicklungsstrategie;

Tabelle 2

Klassifizierung von Marketing-Wachstumsstrategien

\begin{tabular}{|l|l|}
\hline $\begin{array}{l}\text { Die strategische Hauptrichtung des } \\
\text { Wachstums }\end{array}$ & \multicolumn{1}{|c|}{ Eine Art Grundstrategie } \\
\hline Intensives Wachstum & $\begin{array}{l}\text { Tiefe Marktdurchdringung } \\
\text { Die Marktentwicklung } \\
\text { Die Produktentwicklung }\end{array}$ \\
\hline Integratives Wachstum & $\begin{array}{l}\text { Direkte Integration } \\
\text { Die Reintegration } \\
\text { Vertikale Integration } \\
\text { Horizontale Integration }\end{array}$ \\
\hline Das Diversifikation & $\begin{array}{l}\text { Vertikale (konzentrische) Diversifikation } \\
\text { Horizontale Diversifizierung } \\
\text { Konglomerative Diversifikation }\end{array}$ \\
\hline
\end{tabular}

- die Suche nach neuen Märkten für die bestehenden Produkte des Unternehmens; falls verfügbar - Marktentwicklungsstrategie;

- ein neues Produkt auf dem bestehenden Markt anzubieten, ist eine Produktentwicklungsstrategie.

Integrative Wachstumsstrategien (vom Begriff "Integration" - Inklusion) sind Strategien, die eine Leistungssteigerung eines Unternehmens infolge der Zusammenarbeit mit anderen Unternehmen implizieren. Je nachdem, mit wem das Unternehmen fusioniert, werden die folgenden Arten von Strategien unterschieden: direkte Integration, umgekehrte Integration, vertikale Integration, horizontale Integration.

Bei einer direkten Integrationsstrategie wird ein Hersteller mit einem Wiederverkäufer kombiniert. Bei der umgekehrten Integrationsstrategie wird der Hersteller mit einem Lieferanten für Material und technische Ressourcen kombiniert. Wenn die Anstrengungen von Zulieferern, Herstellern und Zwischenhändlern kombiniert werden, ist dies eine Strategie der vertikalen Integration mit der Schaffung von Vertriebskanälen. Eine übliche Form der vertikalen Integration sind vertikale Marketing-Marketing-Systeme, die die Einheit der Interessen aller Mitglieder des Vertriebskanals gewährleisten. Das Interesse 
wird dadurch geweckt, dass einer der Teilnehmer eine führende Rolle spielt und somit die Aktivitäten der anderen Teilnehmer steuert.

Die Strategie der tiefen Marktdurchdringung bedeutet, das Umsatzvolumen und den Marktanteil eines Unternehmens zu erhöhen, ohne seine Warenmarktposition auf Kosten bestehender Waren in bestehenden Märkten zu verändern. Es kann in zwei Richtungen implementiert werden:

1) Die Umsatzsteigerung für bestehende Verbraucher:

- den Verbraucher zu überzeugen, den Verbrauch der Waren zu erhöhen

- den Verbraucher überzeugen, die Nutzungshäufigkeit zu erhöhen;

2) die Gewinnung neuer Verbraucherprodukte, die Produkte von Wettbewerbern verwenden, für die Produkte des Unternehmens.

Die Strategie der tiefen Marktdurchdringung zeichnet sich durch ein geringes wirtschaftliches Risiko aus und wird umgesetzt durch:

- die Aktivierung von Werbemaßnahmen;

- der Einsatz von Verkaufsförderungsinstrumenten;

- die Erhöhung des Dienstleistungsniveaus von Waren;

- der Ausbau des Vertriebsnetzes;

Marktentwicklungsstrategie bedeutet die Anpassung bestehender Waren des Unternehmens an die neuen Märkte, wenn das Unternehmen mit diesen Waren in neue Märkte eintritt, die durch langfristige Absatzchancen, ein hohes Geschäftsrisiko und die Notwendigkeit erheblicher Kosten für die Untersuchung der Vertriebskanäle gekennzeichnet sind.

Produktentwicklungsstrategie bedeutet die Änderung des Produkts eines Unternehmens oder seiner qualitativen Parameter (Stil, Image, Erweiterung der Produktlinie) für das bestehende Verbraucherspektrum, dh das Unternehmen bietet ein verbessertes Produkt an oder erweitert sein Produktsortiment. Die Strategieumsetzung ist möglich durch:

- die Verbesserung der Warenqualität;

- die Entwicklung neuer Produktmodelle;

- die Entwicklung neuer Produkte.

3. Diversifikationsstrategien werden angewendet, wenn ein Unternehmen in anderen Geschäftsbereichen neue Chancen eröffnet. In einigen Fällen kann eine solche Strategie erforderlich sein, wenn der Markt, auf dem das Unternehmen tätig ist, schrumpft und das Unternehmen gezwungen ist, nach anderen Aktivitäten zu suchen. Folgende Diversifikationstypen werden unterschieden: vertikale (oder konzentrische), horizontale und konglomerate Diversifikation.

Vertikale Diversifizierung - wenn ein Unternehmen anfängt, Produkte zu produzieren, die technologisch und vermarktungsbezogen $\mathrm{zu}$ bestehenden Firmenprodukten sind.

Die horizontale Diversifizierung beinhaltet den Eintritt in neue Geschäftsbereiche, die mit der Erfüllung der Bedürfnisse bestehender Kunden (Verbraucher) des Unternehmens verbunden sind. Ein Unternehmen, das eine bestimmte Art von Produkt oder Dienstleistung herstellt, kann von seinen Kunden Informationen über die Notwendigkeit anderer Arten von Waren und Dienstleistungen und die Nutzung dieser Gelegenheit erhalten.

Konglomerative Diversifizierung ist die Entstehung neuer Unternehmen, die in keiner Weise mit der vorhandenen Technologie oder den Bedürfnissen bestehender Unternehmen in Verbindung stehen. Diese Art der Diversifikation erfordert die höchsten finanziellen Kosten und steht nur großen Unternehmen zur Verfügung. 
Daher wird die Strategie als umfassender Geschäftsplan definiert, der auf der Grundlage eines kreativwissenschaftlichen Ansatzes entwickelt wird und fest entschlossen ist, die langfristigen globalen Ziele des Unternehmens zu erreichen. Jede Marketingstrategie definiert den Vektor des Handelns des Unternehmens gegenüber Verbrauchern und Wettbewerbern. Es ist langfristig ausgerichtet; ist ein Mittel zur Verwirklichung der Marketingziele des Unternehmens; basiert auf den Ergebnissen der Marketingstrategieanalyse; hat eine gewisse Unterordnung in der Hierarchie der Unternehmensstrategien; bestimmt die Marktrichtung des Unternehmens; ist Teil der Entwicklung einer Marketingstrategie, die eine bestimmte Logik, Konsistenz und Zyklizität aufweist.

\section{Verweise:}

1. Мочерний, С.В.(ред.). (2002). Економічна енциклопедія (Т.1-3). Київ: Видавничий центр «Академія».

2. Мак-Дональд, М. (2010). Стратегическое планирование маркетинга (пер. с англ.). СПб.: Питер.

3. Біловодська, О.А. (2010). Маркетинговий менеджмент. Київ: Знання.

4. Котлер, Ф., Армстронг, Г., Сондерс, Дж. \& Вонг, В. (2012). Основы маркетинга (пер. с англ.). М., СПб., К.: ИД «ВильямС».

5. Ромат, Е. (2016). Реклама: практическая теория. (9-е изд.). СПб.: Питер.

6. Гаркавенко, С. С. (2009). Маркетинг. (4-е вид.). Київ: Лібра.

7. Дмитрук, М. (2003). Стратегічний маркетинг: данина моді високих понять чи інструмент конкурентної боротьби? Маркетинг и реклама, (5-6), 32-37.

8. Куденко, Н. В. (2010). Стратегічний маркетинг. (2-е вид.). К.: КНЕУ

9. Ансоффф, И. (2008). Новая корпоративная стратегия. СПб.: Изд-во «Питер».

10. Morgan, N, Hui, Feng, H., Whitler, K., Simos Char, S. (2018). Research in Marketing Strategy. Journal of the Academy of Marketing Science, 47(1). DOl: 10.1007/s11747-018-0598-1.

\section{FORMATION OF PRINCIPLES OF ORGANIZATIONAL TRANSFORMATION OF NAFTOGAS GROUP}

Olga Ovetska

$\mathrm{PhD}$, Associate professor, Senior Lecturer at Department of Management and Administration Institute of Economics and Management Ivano-Frankivsk National Technical University of Oil and Gas

UKRAINE

The further promotion of reforms initiated in the oil and gas sector in the context of the implementation of transformational mechanisms (for the period up to 2020) and strategic development goals until 2035, which have been defined by the new Energy Strategy of Ukraine [1], necessitated the formation of a number of priorities by the Oil and Gas Group's management including, inter alia, the creation of a robust and flexible organizational structure, the Gas Division. 
The essence of organizational transformation of the Gas division is to adhere to the best practices and to implement a streamlined organizational structure and updated processes. This reform also includes a review of the organizational structure of gas exploration and production assets. These assets form the basis of an asset-based organizational structure in hydrocarbon exploration and production. The new organizational model entails the transfer of most of the responsibility to the level of asset managers, which, in particular, will manage all existing gas and oil fields within a specific geographical region; are responsible for the extraction, cost, profit and security of their asset, etc. [2].

The organizational transformation will entail the creation of a classic trading organization with a division into Front Office, Middle Office and Back Office gas sales. First of all, the transformation will be aimed at strengthening the unified decision-making process based on the portfolio for import and trade operations, creating a strong analytical center to support decision making in all areas within the competence of the gas division and the Naftogaz Group.

Therefore, we are talking about the need to develop a comprehensive system for managing the development of oil and gas companies in a market environment, which should be based on the relevant management principles [3] in the conditions of substantial reformatting of the principles of functioning of the gas market of Ukraine (with the adoption of the Law "On the Natural Gas Market"). In particular, the most relevant are the following principles: system duality and institutional conditioning (this principle determines the possibility of recurrence of developmental situations caused by the dependence of the structure and the entity, as well as the influence of the institutional environment); dynamic compliance with the goals and needs of the organization (implementation of this principle determines the multilevel structure of organizational development, which involves the interaction of structures that ensure the development of the organization, and social structures (institutions) originating from the organizational development system) and viability (implementation of this principle involves determining the conditions of normal functioning and development of the system, as well as forms of its interaction with the elements of the internal and external environment).

\section{References:}

1. Security, energy efficiency, competitiveness: Ukraine's Energy Strategy for the period up to 2035 (Decree of the Cabinet of Ministers of Ukraine). No. 605-p. (2017). Retrieved from http://www.kmu.gov.ua/control/uk/cardnpd?docid $=250250456$.

2. NAK Naftogaz Group 2018 Report. (2019). Вилучено 3 http://www.naftogaz.com/www/3/nakweb.nsf/0/9B0566E71C6B0F9CC2257EDD006E558B?Ope nDocument\&Expand $=3 \&$.

3. Gorbatovskaya, N.V. (2012) Management of Organizational Development of Industrial Enterprises (Ph.D. in Economics). Makeyev Economic and Humanities Institute. Makeevka, Ukraine. 


\title{
INTERNATIONAL TRADE AND FOREIGN TRADE POLICY OF UZBEKISTAN
}

\author{
Narziyev Sanjarbek Asqarovich \\ student of International Trade and Law Faculty, \\ Kyiv National University of Trade and Economics
}

UKRAINE

International trade is a form of communication between producers of different countries, arising on the basis of the international division of labor, and expresses their mutual economic dependence.

Structural changes occurring in the economies of countries under the influence of the scientific and technological revolution, specialization and cooperation of industrial production strengthen the interaction of national economies. This helps boost international trade.

International trade, mediating the movement of all intercountry commodity flows, is growing faster than production. According to studies by the World Trade Organization, for every $10 \%$ increase in world production, there is a $16 \%$ increase in world trade. This creates more favorable conditions for its development. When trade fails, the development of production slows down.

The term "foreign trade" refers to the trade of a country with other countries, consisting of paid import (import) and paid export (export) of goods.

Diversified foreign trade activities are subdivided according to commodity specialization into: trade in finished products, trade in machinery and equipment, trade in raw materials and trade in services.

International trade refers to paid aggregate trade between all countries of the world. However, the concept of "international trade" is also used in a narrower sense. It means, for example, the total commodity turnover of industrialized countries, the aggregate commodity circulation of developing countries, the aggregate commodity circulation of countries of a continent, region, for example, countries of Eastern Europe, etc.

World prices vary depending on the time of year, place, conditions for the sale of goods, features of the contract. In practice, the prices of large, systematic and sustainable export or import transactions that are concluded at certain centers of world trade by well-known firms - exporters or importers of the corresponding types of goods are accepted as world prices. For many commodities (cereals, rubber, cotton, etc.), world prices are set in the course of operations on the world's largest commodity exchanges.

Sooner or later, all states face the dilemma of choosing a foreign trade national policy. For two centuries, heated discussions have been held on this topic.

It is in the interest of each country to specialize in production in which it has the greatest advantage or least weakness and for which the relative benefit is greatest.The political and economic independence gained by the republic in 1991 fundamentally changed the foreign economic relations of Uzbekistan. The state monopoly on foreign trade, in which the import and export of the entire 
former Union was centrally planned and the state regulated the distribution of foreign exchange reserves, was destroyed.

With independence, Uzbekistan gained the opportunity to pursue an independent foreign trade policy in its own interests. There was a need to create a mechanism for conducting foreign economic activity based on the principles of a market economy.

The strategy aimed at a worthy entry of the national economy into the world economy was built on the basis of taking into account the economic potential of the republic, assessing the real situation and was focused on solving the main goals of the political and economic development of Uzbekistan. At the same time, economic reform measures were synchronized to create competitive domestic markets and liberalize foreign economic activity.

At the first stage of liberalization of foreign economic activity, a regulatory framework was developed and adopted that resolved a number of fundamental issues. Firstly, the right to independent entry of enterprises to the foreign market was enshrined in law. Secondly, regardless of the form of ownership, the conditions for entering foreign markets were established the same for all business entities.

At the same time, the state retained the exclusive right to export cotton, silk, astrakhan, marble, gold and other goods constituting republican export resources. Foreign economic activity as a whole was under its strict control; for the most part export and import operations, tariff and non-tariff regulation measures were applied. The centralization of export revenue in the hands of the state, which made it possible in an unprecedentedly short time to solve the problems of structural adjustment, required administrative control over the country's currency resources.

The measures taken to import substitution of a number of strategic resources contributed not only to a significant increase in the political and economic security of the country, but also to the creation of conditions for real liberalization of foreign economic relations.

In the course of economic reforms, the liberalization of foreign economic activity has become a key element in solving the main tasks of economic policy. The transformations in the foreign economic sphere carried out in 1994-1995 were aimed primarily at a more effective inclusion of Uzbekistan in the international division of labor and at the formation of economically sound trade relations with foreign countries. The process of market distribution between domestic and foreign manufacturers began to be implemented on a civilized basis.

With the formation of objective and subjective conditions, the intensification of market relations and mechanisms for the functioning of the economy, the system of managing foreign economic relations of the republic has improved by limiting administrative methods of regulation in favor of economic ones.

The new strategy of the Republic of Uzbekistan in the field of foreign economic relations includes:

- decentralization of export-import operations;

- Strengthening control over the export and import of goods for state needs; 
- reduction in exports of goods that are not strategically important for the state;

- tightening control over incoming foreign exchange earnings from the export of strategically important goods;

- stimulation by all measures of the state policy of attracting foreign investment and the development of export activities.

Thus, in the course of radical economic reforms, foreign economic activity in the republic began to be based on a fundamentally new regulatory framework and state regulation mechanism, developed in accordance with the requirements of the country's adaptation to the conditions of a market economy and integration into the global economic space.

In foreign economic activity, in addition to solving such traditionally important tasks as export development - the main source of foreign exchange earnings and ensuring import supplies, the following functions are carried out:

- implementation of the modern concept of integration of the Uzbekistan economy into the system of world economic relations;

- accumulation of additional financial resources necessary to continue the structural adjustment of the economy and its balanced growth;

- search for ways of mutually beneficial cooperation in the context of ongoing economic reform;

- protection of the interests of the national market from the adverse effects of global market conditions and foreign competition at the stage of establishment of market relations in Uzbekistan.

Currently, Uzbekistan carries out foreign trade with more than 120 countries of the world. In foreign trade relations of Uzbekistan there are two main areas:

- with the CIS countries,

- with foreign countries.

Uzbekistan is entering a new era of international trade and investment. The February talks with the European Union in Tashkent testify to this. The leadership of Uzbekistan is in the process of replacing the Partnership and Cooperation Agreement with the European Union, concluded in 1999, with a new agreement that meets modern conditions.

In addition, during recent visits by President Shavkat Mirziyoyev to South Korea, the United States and Western Europe, theses were voiced that Uzbekistan would soon join the World Trade Organization (WTO), and partner countries promised to help Uzbekistan in the exchange of experience and technical assistance in the process of joining WTO.

In addition to these two international transactions, another phenomenon is expanding trade as a result of improved mutual trade relations with Central Asian countries and Russia. Another phenomenon is the interest of the country's leadership in participating in the initiative of the neighbor of the People's Republic of China "One belt - one way". All this suggests that one of the most important priorities of the foreign policy of the government of Uzbekistan is diversified foreign trade directions.

In the 21st century, markets in many countries have become open thanks to the WTO, regional or bilateral trade agreements. If the state wants to sell its products on the market of another state, then it needs to establish legal relations 
with this country. And if the state has not done so, high tariffs and non-tariff barriers to its products will be expected.

Uzbekistan has concluded trade agreements with $11 \mathrm{CIS}$ countries, and in accordance with them the country's products can be imported into the territory of countries without import customs duties. In addition, Uzbekistan has agreed with 45 countries on the mutual provision of the most favorable trade regime. It also prevents discrimination of domestic goods and services in other countries.

The only trade agreement in the CIS in which Uzbekistan is a member is the CIS Free Trade Zone, which Uzbekistan joined in 2014. The agreement creates a good legal basis for expanding trade between the Customs Union of the Eurasian Economic Union (CU EAEU) and Uzbekistan. At the same time, the terms of the agreement are valid for Uzbekistan on several conditions. According to the agreement, until December 31, 2020 or before Uzbekistan joins the WTO, the parties are exempted from the obligation to provide a national regime to each other. It is obvious that the government of Uzbekistan pays great attention to the agreement concluded with the European Union. Because it was the Uzbek side that proposed renewing the treaty of 1999 in 2017, and official negotiations began in November 2018 in Brussels. It should be noted that this all indicates a warm perception by the European Union of ongoing reforms in Uzbekistan. So far, from the countries of Central Asia, the European Union has signed such an expanded agreement only with Kazakhstan.

The Enhanced Partnership and Cooperation Agreement with the European Union is expected to include more issues than the 1999 agreement. The first round of negotiations took place in Tashkent on February 4-7, 2019. The next round of negotiations will take place in Brussels. So far, the exact date for the end of the negotiations is not known. In the case of Kazakhstan, reaching such an agreement took about three years, and the parties had to go through a total of eight rounds of negotiations.

Key issues are: how much Uzbekistan wants democratic reforms and successful renewal of human rights institutions, as well as how well it can bring legislation into line with EU legislation. With regard to trade and investment, the reduction of import duties for the EU, the opening of domestic markets for European investors, the elimination of technical barriers, the protection of intellectual property and compliance with WTO criteria play an important role.

\section{References:}

1. Mikloshevskaya, N.A.\& Kholopov, A.V. International Economics. M .: Moscow State University M.V. Lomonosov. Publishing House "Business and Service".

2. Kamaev, V. D. (ed.). (1996). Fundamentals of economic theory. M.: Publishing House of MSTU. N.E. Bauman, 1996.

3. Avdokushin, E.F. (1999). International economic relations. Tutorial. M .: Marketing,. 


\section{SMМ-СТРАТЕГІЯ ЯК ЕФЕКТИВНИЙ ІНСТРУМЕНТ В РЕКЛАМНІЙ ДІЯЛЬНОСТІ ПІДПРИЄМСТВ}

Москаленко Мар'яна Максимівна

Здобувач вищої освіти фракультету економіки та менеджменту Харківський національний університет будівництва та архітектури

Науковий керівник: Опікунова Наталія Валентинівна ст. викладач кафедри менеджменту та публічного адміністрування Харківський національний університет будівництва та архітектури УКРÄ̈HA

Високий рівень конкуренції на ринку та комп'ютеризація бізнесу призвели до стрімкого розвитку маркетингу та його трансформації. Одним з них $є$ SMM (social media marketing або маркетинг у соціальних мережах). В пошуках нових шляхів залучення клієнтів та впливу на цільову аудиторію компанії обирають соціальні мережі в якості головного майданчика продажу, що є основною задачею SMM.

Головною перевагою SMM є гарантія збільшення цільової аудиторії та ріст продаж при мінімальних затратах на просування. Також такий вид маркетингу дозволяє більш точно та цілеспрямовано впливати на потенційних клієнтів, сигментуючи їх за географічним показником, віком та інтересами. Саме ці переваги та вимоги сучасності й актуалізують тему даної роботи.

Сьогодні існує багато майданчиків для продажу та просування товару чи послуг в Інтернеті. Проте серед SMM-спеціалістів найбільшою популярністю користуються такі: Facebook, Instagram, Pinterest, Twitter, YouTube. Кожен з них має ряд переваг та недоліків. Найбільш розповсюдженим майданчиком, у якому сьогодні ведеться бізнес $€$ Instagram.

SMM - стратегія - це комплекс заходів для просування в соціальних мережах та мережі Інтернет [1].

Створення ефективної стратегії для має складатися з декількох етапів.

На першому етапі необхідно визначити один глобальний тезис, щодо того, навіщо існує бренд. Щоб зрозуміти чого ми хочемо досягти і навіщо, необхідно відповісти на прості питання: «Що ми робимо?», «Де ми це робимо?», «Коли ми це робимо?», «Для кого?» і «Навіщо, чого хочемо досягти?». Це найголовніший етап. Якщо знехтувати ним, то стратегія буде провальною [1].

Другий етап - розділити велику мету на декілька завдань. Тобто фрормуємо кроки, якими ми досягнемо мети.

Третій етап - визначення для кого ми робимо нашу продукцію, або послугу. Це дозволить сформувати відповідний контент, який буде цікавий саме нашим користувачам. Щоб визначити цільову аудиторію необхідно скласти портрет споживача, визначивши наступні складові: місцезнаходження споживача; вік; стать; інтереси споживача; освіта споживача; сфера діяльності; рівень доходу; сімейний статус; веб-ресурси, які він відвідує на регулярній основі; його мотивація; його страхи, сумніви та стереотипи, потреби.

Розуміння всієї цієї інфоомації дозволить також сегментувати покупців для реклами за одним із показників. Це підвищить ефективність реклами [3]. 
Четвертий етап - ключові показники ефективності або KPI (Кеу Performance Indicators) завжди відповідають меті та прописуються у цифрах. Тобто формуючи мету прописуємо скільки часу ми можемо витратити, скільки коштів, тощо.

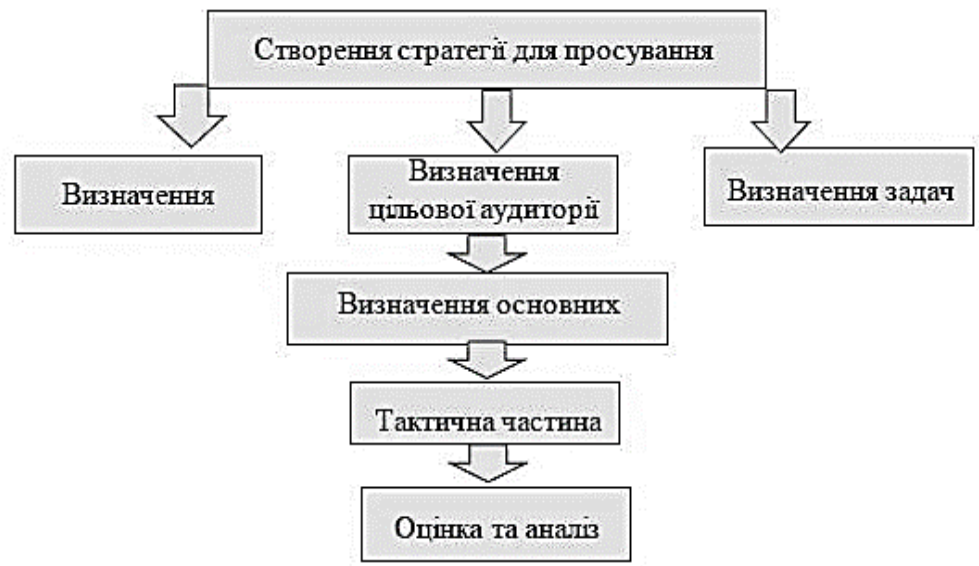

Рис. 1. Етапи створення стратегії просування [2]

Основними показниками KPI можуть бути: статистика охоплення та зацікавленості; кількість і вартість продажів; кількість і вартість отриманих лідів; кількість і вартість трафріку; прямі конверсії в особистих повідомленнях або коментарі; мікроконверсії (дзвінки, прямі звернення в дірект) [4].

Визначення KPI дозволить оцінити ефективність стратегії та скорегувати ії, якщо необхідно.

П'ятий етап - тактична частина стратегії.

Необхідно визначити тип контенту, соціальну мережу, у якій будемо публікувати, частоту постингу, tonevoise, реклама $[2,3]$.

Так як соціальні мережі дуже «вимогливі» до якісного зображення, то необхідно рекламувати оригінально, виділяючись серед інших товарів у мережі. Для цього необхідно враховувати наступні чинники:

1. Заголовок має чіпляти та звертати на себе увагу.

2. Текст має бути читабельним, легким для сприйняття.

3. Заклики до дії дають гарний фідбек. Використовуйте заклики до дії: запрошення до обговорення, висловленню думки, оцінки.

4. Візуальна складова повинна бути якісною та відповідати єдиному стилю [5].

Також необхідно визначити tonevoise, тобто манеру, у якій ми спілкуємося з клієнтами. Врахувати треба все: гумор, звернення на «ти» чи «ви», мова звернення.

Наступним важливим елементом є таргетована реклама. Facebook та Instagram дають можливість створювати рекламні оголошення, які спрямовані на сегментовану аудиторію. Тобто рекламні оголошення демонструються саме цільовій аудиторії, відібраної за критеріями (стать, інтереси, місце проживання, 
освіту та ін.). Кожній групі користувачів, об'єднаної загальним критерієм, можна показувати окреме рекламне оголошення [6].

Одним з видів реклами $є$ ретаргетінг, який використовується для повернення аудиторії, яка відвідала вашу сторінку, але не зробила цільового дії. Ретаргетінгове оголошення повертають користувача на сайт. Такі рекламні оголошення не безкоштовні $[6,7]$.

Шостий етап - оцінка і аналіз.

Кожна соціальна мережа дає змогу проводити аналіз діяльності за наступними показниками: щомісячне збільшення кількості відвідувачів та підписників; залученість користувачів, їх активність;кількість відвідувань групи новими користувачами; кількість користувачів, які відвідали сайт, перейшовши з соціальних мереж; збільшення кількості згадок про ваш бренд в мережі [8].

Також для аналізу використовують Google Analitics. Цей ресурс підходить для брендів, які мають окремий сайт. В аналітиці можна побачити скільки користувачів прийшли з соціальних мереж, коли та які дії вони виконували [9].

Висновки. Таким чином, SMM-стратегія - це складний комплекс заходів для просування в соціальних мережах, який складається з декількох етапів. Кожен етап $€$ важливим та залежним від попереднього. Вони повинні йти послідовно. У разі пропущення або ігнорування будь-якого етапу стратегія будується невірно та у майбутньому буде неефективна. SMM-стратегія $\epsilon$ реалізованою тільки за умов досягнення КPI (ключових показників ефективності).

\section{Список використаних джерел:}

1. Забеліна, М. О. (2017). SMM - стратегія як інноваційна технологія в соціокультурному просторі. В.М.Шейко (ред.) Харків: Вісник Харківської державної академії культури.

2. Курбан, О. (2014). Стратегія і тактика сучасної інформаційної активності у соціальних мережах № 9. (с. 42 - 45) Київ: Вісник Книжкової палати.

3. Грищенко, О.Ф. (2013). Соціальний медіа маркетинг як інструмент просування продукту підприємства. Маркетинг і менеджмент № $4 . \quad$ (с. 86 - 95) Київ: Маркетинг і менеджмент інновацій.

4. Ермолова, Н. (2013). Продвижение бизнеса в социальных сетях. Москва.

5. Кияниця, Є. (2014). Перспективи використання технологій паблік рілейшнз у соціальнокультурній сфері України № 9.

6. Реклама в Facebook. Вилучено 3 https://websait.uz.ua/pos/uhy/reklama-v-sotsialnyhmerezhah/reklama-v-facebook/.

7. Ліпенцев, А. А. (2011). Переваги використання соціальних мереж у маркетингових комунікаціях на прикладі сайтів Twitter i Facebook. 69-та студентська науково-технічна конфреренція. Секція: Економіка і менеджмент. 1 листопада, 2011, Львів, Україна.

8. Парабеллум, А. (2013). Социальные сети. Источники новых клиентов для бизнеса. Санкт-Петербург.

9. Романишин, С.Б., Греськів, І. Р. (2015). Особливості маркетингової діяльності в соціальних мережах. Менеджмент та підприємниитво в Україні: етапи становлення $i$ проблеми розвитку. Львів: Вісник Національного університету «Львівська політехніка». 


\section{SOME WAYS TO IMPROVE THE PROFESSIONAL EDUCATION IN UKRAINE}

\section{Kharkiv Educational and Scientific Institute "Universty Oenchik \\ Iryna Denchik
sity of Banking» \\ UKRAINE}

Professional education is the basis of socio-economic development of society, the basis of many areas in the life of the state, means of personal and professional development and self-affirmation of the individual.

The formation of policies and management of professional education should be carried out in accordance with the general objectives of the educational process and taking into account future and existing national and regional socio-economic requirements.

The essence of the main questions of today that need to be answered is not what or how to teach (although, of course, these are the most important problems of education), but in what direction (specialty), for which branch of the economy to teach. It is necessary to determine the professional characteristics of our graduate in connection with the dynamic changes in the production and social processes of society. At the present stage, professional education is the best suited to meet the needs of the individual and society in self-development. The solution to these problems is seen in the creation of a system of continuing professional education. Now there is a spectrum of problems without the solution of which high-quality training of mid-level specialists is not possible.

The first block of problems is methodological. It concerns the content and essence of the basic concept of the quality of professional education. It is necessary to develop methodological tools for identifying, studying and accounting for all possible consumers of professional knowledge. Generalized criteria for the quality of training of mid-level specialists include the following groups: employer satisfaction (production); graduate (personality); society of higher education as a consumer of university graduates (education system).

The second block is the quality management of specialist training. The main thing here is the assessment component, focused on identifying the correspondence between the goals and results of the educational process. This, in turn, requires the development of an objective multi-level pedagogical toolkit that allows for a quantitative assessment of the results, the monitoring the quality of training of specialists. It is advisable to strengthen the diagnostic training and retraining of engineering and teaching staff, to develop and accumulate diagnostic methods for improving the education management system.

The third block is resource support for the quality of training of specialists. In order for an educational institution to achieve a consistently high quality in the preparation of graduates, it is necessary to ensure that the following group of basic educational activities is implemented. The is a need to make the management motivated, to improve the personnel, methodological, informational, material, technical, regulatory and financial components of professional training.

It is quite clear that in order to modernize professional education in new conditions a radical restructuring of the educational process is necessary for the 
quality training of students, the search for new forms of interaction with employers, businesses, and interested structures.

The fundamentally new conditions for the training of skilled workers and specialists in professional education institutions both in the EU countries and in Ukraine ensures the continuity of educational systems and the possibility of getting integrated and differentiated by the level of professional education.

Also in the general context of educational reform a prominent place has been occupied by the search for more effective forms and methods of management on which the real results of educational reforms depend to a large extent.

\title{
THE APPLICABILITY OF THE TAX REFORM ON THE IMPLEMENTATION OF THE DEDUCTIBLE CAPITAL TAX
}

\begin{abstract}
Iryna Tarasiuk
applicant for higher education at the Faculty of Economics National University of Life and Environmental Sciences of Ukraine

Scientific adviser: Svitlana Derevianko PhD in Economics, Associate Professor of Accounting and Taxation Departments National University of Life and Environmental Sciences of Ukraine
\end{abstract}

UKRAINE

There has been a lot of talk lately about a legislative initiative such as a deductible capital tax that should be replaced by a corporate income tax. In fact, the idea of a deductible capital tax is not new. This tax model has been operating in Estonia since 2000, ranking 18th in the Doing Business ranking for ease of doing business (by comparison, Ukraine ranked 64th) [1]. This issue raises a lot of debate, and the bill has both convinced supporters and clear opponents. Let's figure it out. Currently, two draft capital tax bills have been registered with the Verkhovna Rada. The point is that money is not taxed unless the entrepreneur considers it a profit and does not withdraw from the company.

What's the difference? To date, any penny that goes into the company account after all administrative and production deductions is automatically called a profit, from which is paid from $18 \%$ to $20 \%$ of income tax. And the deductible capital tax is paid only when the enterprise calls the money a profit and withdraws it from the enterprise. At the same time, the money that remains inside the business entity is current assets and is not taxable.

The object of taxation on the deductible capital tax is defined as capital withdrawal operations and operations equated to capital outflow operations. Capital withdrawal operations will include the payment of dividends in favor of the taxpayer, the payment of a portion of the profits to state unincorporated, state-owned or utility companies, the return of contributions to the owner of the corporate rights - the taxpayer (in the amount exceeding the value of the contribution made by the capital or the paid capital such a legal entity), etc.

Transactions that are commonly used to erode the tax base in Ukraine (paying interest on loans to companies in "low-tax" jurisdictions, paying dividends to nonresidents, investing abroad) become a direct object of the deductible capital tax. 
The draft law [2] prevents tax conventions from being abused by applying reduced or zero rates of tax to certain types of non-resident income, since deducted capital tax is paid solely by taxpayers (that is, in principle there is no withholding tax on any non-resident income subject to tax conventions).

The taxpayers of the deductible capital tax are supposed to identify residents and non-residents.

It is proposed to apply the following capital duty tax rates: $15 \%$ - for capital withdrawal operations; $20 \%$ - for operations equivalent to capital withdrawal operations (except for the operations described below, which are taxed at the rate of $5 \%$ ); $5 \%$ - to the funds paid for the execution of debt obligations to non-resident related parties.

The advantages of such a taxation model are obvious. First, incentives are created for business and investment activity. According to the experience of Estonia, the inflow of foreign investments increased immediately. However, for some reason, resident investors were in no hurry to increase their activity. Obviously, they did not believe such "happiness". Second, businesses do not need to downgrade their financial performance, and thus, financial statements of businesses can become more transparent and attractive to investors and banks. Third, it is easy to check tax liabilities, since it is difficult to conceal transactions that are subject to taxation. It will be enough for the tax authorities to check the existence of such operations. Accordingly, the topic of controversy will disappear: whether or not costs can be attributed? do I need to adjust? (though the reason for speculation around normal prices will remain the same).

\title{
References:
}

1. Ease of Doing Business rankings in 2019. (2019). Retrieved from from https://www.doingbusiness.org/en/rankings?region=europe-and-central-asia

2. Draft Law on Amendments to the Tax Code of Ukraine on the introduction of capital surplus tax and the implementation of anti-taxation standards and the removal of profits abroad in 2019. (2019). Retrieved from http://w1.c1.rada.gov.ua/pls/zweb2/webproc4_1?pf3511=66488

\section{THE UKRAINIAN «BASE EROSION AND PROFIT SHIFTING» PLAN IMPLEMENTATION PARTICULARITY}

\author{
Valerii Danylenko \\ Ph.D. (Economics), Senior Lecturer at the \\ Department of Agrologistics and Supply Chain Management \\ Kharkiv Petro Vasylenko National Technical University of Agriculture \\ UKRAINE
}

Control over the currency transactions of individuals and legal entities is still quite tangible, but further easing is directly dependent on the implementation in Ukraine of the BEPS (Base Erosion and Profit Shifting) plan.

The BEPS plan is 15 measures developed by the Organization for Economic Co-operation and Development aimed at combating the tax base erosion and the concealing of profits from taxation. At their core, these are legislative or operational 
barriers to applying the most popular tax evasion schemes. The minimum task for Ukraine is to introduce 4 steps aimed at combating the abuse of tax benefits.

A lot has been written about the implementation of the BEPS plan in Ukraine in the last two years, many changes in taxation approaches are mentioned, the feasibility of which will become quite real after Ukraine joins the international exchange of information, which will give the Ukrainian tax an opportunity to see the often unseen international relations of Ukrainian business (Ukraine signed under this obligation, but without specifying a specific date), however, until the last days, the implementation of the BEPS plan remained more likely in the status of a prospect [1].

The recent relevance of the BEPS topic has been determined by two events: the first event is the forthcoming entry into force in December this year of the Multilateral Convention on the Implementation of Tax-Related Measures to Prevent BEPS (MLI Convention); the second one is the registration in the Verkhovna Rada of bill No. 1210, which proposes significant changes to the Tax Code and which caused strong reactions from business.

Further, we discuss what these two acts, with one degree or another, in one version or another, will change in the taxation of Ukrainian business.

MLI Convention: The Convention seeks to verify the reality of business transactions subject to tax credits under tax agreements and to combat the practice of masking permanent missions.

Of the principal two innovations introduced by the Convention are significant:

- Principal Purpose Test when transferring interest or royalties (not dividends) to a non-resident;

- introduction of criteria for the project's duration in Ukraine in order to recognize the business of a non-resident here as a permanent establishment.

Principal Purpose Test involves judgment that the main goal of the operation (the transaction itself or the creation of a non-resident company that receives income from such a transaction) is a tax benefit application. Such a test involves a comprehensive analysis of the transaction, its economic feasibility, reality and managerial independence of the income recipient (tax analysis will be able to do the same as that analyzed by banks during financial monitoring: a business goal, the presence of a director, staff, a wage fund, real office, and other aspects indicating the reality and commercial nature of the operation to which the benefit applies). And if by the result of such an analysis it will be clearly visible that the operation was carried out solely for the purpose of deriving interest towards a convenient jurisdiction (the operation will not find economic meaning from the tax office perspective), then, in all likelihood, it will be necessary to wait for a notification on additional charge at the $15 \%$ rate repatriation tax.

Bill No. 1210 is one of three tax bills for large and medium-sized businesses that, at the moment of article preparation, are under consideration in the Verkhovna Rada, namely the most recent, sensational in many respects, and, moreover, having urgent status. This bill caused a great public outcry, even international business organizations considered some of its intentions reckless. Nevertheless, in this bill, among other provisions, the key steps of the BEPS plan were specifically embodied (even above the minimum that Ukraine was obliged to fulfill in the first stage), and this gives an idea of the form in which the BEPS plan is most likely (it is very possible that it will be very soon) to be implemented in Ukraine.

Criticizing the bill's individual provisions, it often calls for the idea of replacing income tax with tax on capital withdrawn (the bill that offers such an alternative 
received generally positive feedback from the business over the past year) [2]. Following the example of Estonia, Latvia, Georgia, in the case of the tax on the withdrawn capital introduction, the amounts paid by Ukrainian companies abroad at different rates depending on the types of income will be subject to taxation. The introduction of such a tax would motivate businessmen to reinvest profits in Ukraine, and concealing profits from taxation within Ukraine would lose its meaning.

\section{References:}

1. Даниленко, В. В. (2018). Управління конкурентоспроможністю підприємств-виробників зерна в умовах нестабільної кон'юнктури ринку (автореф. дис. кандидата екон. наук). ХНТУСГ: Харків, Україна.

2. Накісько, О. В. \& Даниленко, В. В. (2017). Концептуальні засади управління конкурентоспроможністю сільськогосподарського підприємства. Вісник Харківського національного технічного університету сільського господарства імені Петра Василенка, (185), 290-300.

\section{АКСЕЛЕРАЦІЯ ТА ІНКУБАЦІЯ БІЗНЕСУ: МЕТОДОЛОГІЧНІ ПІДХОДИ ТА ІНФОРМАЦІЙНИЙ ЧИННИК}

Філіппов Володимир Юрійович

канд. екон. наук., доцент кафедри менеджменту Одеський національний політехнічний університет

УКPAÏHA

Питання управління бізнес-процесами гостро постають в компанії, коли на певному етапі іiї розвитку збої у взаємодії підрозділів, менеджерів, співробітників починають носити регулярний характер, при цьому роблячи істотний вплив на ефективність діяльності самої організації. Управління різними бізнес-процесами також можливо за допомогою таких інструментів, як бізнес-інкубатор, або бізнес-акселератор.

Визначаючи роль бізнес-процесів, таки науковці як: О. Амоша, Б. Буркинський, Войнаренко, В. Геєць, В. Гриньова, І. Дмітрієв, О. Кузьмін, І. Сандига, С. Харічков вважають, що таки поняття «бізнес-інкубатор» та «бізнес-акселератор» в останні часи стали одною з основних організаційноекономічних фрорм підтримки підприємництва як соціально-економічного явища, оскільки такий інформаційний чинник пропонує механізм, за допомогою якого підприємці, що висувають привабливі бізнес-стратегії, отримують фінансову, організаційну і консультаційну підтримку для їх реалізації, а також успішне входження на нові ринки підприємствами [1].

Додатково зазначається, що надання безперервної допомоги в період бізнес-акселерації, тобто від первинної ідеї прискорення до першого комерційного успіху, є необхідною умовою і принципом розвитку інноваційних підприємств, проекти яких є більш вразливими та ризикованими [2]. 
Головна відмінність інкубаторів та акселераторів для бізнесу полягає в тому, що в інкубаторі рушійною силою $є$ місце (інфраструктура), де ваша команда буде сидіти і творити, а в акселератор - цінність, яку може нести в собі ваша інновація для ринку [3].

В інкубаторі все направлено на створення бізнесу, навіть якщо людина прийшла один з ідеєю. Тут він може зустріти близьких за духом людей, які допоможуть розібратися, наскільки хороша ідея.

У акселератора відразу перевіряється на живучість і сама ідея, і продукт / сервіс, який вона несе. Але туди варто приходити з уже укомплектованою командою. Головне, чим акселератор допоможе - вийти на ринок з новою концепцією продукту, щоб отримати підтвердження від потенційних клієнтів про його необхідність і цінності.

Отже, якщо майбутній підприємець шукає місце для реалізації ідей, а також якщо йому не вистачає соратників в команду це - бізнес-інкубатор. Якщо підприємець має цілком самостійний колектив, який створив продукт і потребує раді професіоналів про те, як ефективніше вивести його на глобальний ринок або як отримати позитивні відгуки від перших покупців це бізнес-акселератор.

Інкубатори надають, в основному, консалтингові послуги та допомагають презентувати проект інвестору. Іноді - забезпечують майбутніх підприємців офісом, фінансами і технічною базою, організовують освітні заходи. У деяких випадках також пропонуються невеликі інвестиції.

Інкубатори, які зосередилися виключно на консалтингу, як правило, не висувають суворих правил відбору проектів. Їх клієнтом може стати кожен підприємець або команда з ідеєю, а також з бажанням її втілювати.

Що стосується акселераторів, вони працюють індивідуально з проекту, який пройшов конкурс, залучаючи фінансові ресурси і досвідчених експертівменторів. Головне їхнє завдання полягає в тому, щоб спільно зі стартаперам за обмежений період створити інвестиційно-привабливий продукт на рівні робочої версії або прототипу. Нерідко такі проекти згодом отримують венчурне фрінансування від фондів, які працюють безпосередньо 3 даними акселератором.

Відзначимо, що взаємини стартапера з інкубатором можуть будуватися як на платній, так і на безкоштовній основі. У першому випадку за фріксовану плату підприємець отримує доступ до навчальної програми, семінарів і коучинговий сесій. Безкоштовна участь можливо в тому випадку, якщо діяльність інкубатора або конкретну програму фрінансують потенційні інвестори, які потім вибирають серед учасників проекти для спільного розвитку. Розмір частки в стартапі, який отримує акселератор, варіюється в залежності від обсягу фінансування, нематеріального внеску і т.д.

Для вирішення питання розвитку підприємництва велику роль міг би зіграти розвиток мережі венчурних фондів в Україні, бізнес-інкубаторів, технологічних та індустріальних парків. Багато труднощів підприємці мають через відсутність достатньої застави для отримання банківського кредиту. На сьогодні ні банки, ні влада не прагнуть запропонувати бізнесу якесь рішення цієї проблеми. Становище ускладнене ще й тим, що в нашій країні недостатньо розвинуто лізинг (кількість лізингових фірм в Україні становить буквально кілька десятків). 
Значної допомоги надали б і подальший розвиток системи державних гарантій за кредитами бізнесу, реалізація регіональних і національних програм підтримки МСБ, що базуються на конкретному обсязі фінансових i матеріальних засобів.

\title{
Список використаних джерел:
}

1. Філіппов, В. Ю. (2012). Зарубіжний досвід розвитку бізнес-інкубаторів: можливості та обмеження застосування в Україні. Вісник Донецького національного університету економіки і торгівлі імені М. Туган-Барановського, 4(58), 57-62.

2. Дуб, А. Р. \& Хлопецька, М.-С. Б. (2016). Джерела фінансування стартапів та можливості їх залучення в Україні. Соціально-економічні проблеми сучасного періоду України, (1), 87-92.

3. Бойченко, Е. Б. (2017). Проблеми та перспективи розвитку процесів бізнес інкубування в Україні. Ефективна економіка, (2), Вилучено з: http://www.economy.nayka.com.ua/?op=1\&z=6509.

\section{АНАЛІЗ ЕФЕКТИВНОСТІ ВИКОРИСТАННЯ ЛІСОВИХ РЕСУРСІВ ВОЛИНСЬКОЇ ОБЛАСТІ}

\author{
Батієвич Дмитро Миколайович \\ здобувач вищої освіти факультету обліку та фінансів \\ Луцький національний технічний університет
}

Науковий керівник: Жураковська Ірина Володимирівна канд. екон. наук, доцент кафедри обліку і аудиту Луцький національний технічний університет

УКРӒ̈HA

Головною умовою ефективної діяльності підприємств лісового господарства $€$ належне використання земель, дерев та інших лісових ресурсів. Оскільки ліси $€$ найбільшими резерватами різноманітних рослинних i тваринних ресурсів, які $є$ складовими комплексу природних ресурсів, то у даному сенсі розділяємо думку Н.Я. Киргизова [1], який ліс розглядає не як природний ресурс, а як сукупність ресурсів (землі, деревного запасу, недеревних ресурсів). Крім того, лісовіресурси $є$ економічними ресурсами, якіпокладаються в основу створенняматеріальних та нематеріальних благ.Зважаючи на вищенаведене, ми погоджуємось 3 пропозицією О.О. Одношевної та Ю.Л. Якубенко щодо доцільності використання методики аналізу необоротних активів для дослідження лісових ресурсів лісу [2].

Для ефективності використання лісових ресурсів ми пропонуємо визначити наступні показники та провести на їх основі аналіз ефективності використання лісових ресурсів Волинської області. Проте, дослідження даних статистики показало, що провести аналіз за класичними формулами фондовіддачі неможливо. Особливістю лісового господарства $є$ те, що лісові ресурси не оцінені, тому інформація є лише в натуральних показниках, а саме площа лісу 
у гектарах (далі-га), динаміка і структура біологічних активів за видами та показників лісових ресурсів (вік лісу, види порід, площі засадження).

Доцільно приділити увагу наступним показникам, які показують ефрективність використання лісових ресурсів:

1. Продуктивність лісових ресурсів - будемо оцінювати співвідношенням вартості заготовленої деревини або обсягів заготівлі лісопродукції до площ рубок лісу.

2. Фондовіддача лісових ресурсів розраховується як співвідношення вартості заготовленої деревини або обсягу заготовленої деревини загальної площі лісу.

3. Фондомісткість лісових ресурсів розраховується як співвідношення загальної плащі лісу до вартості заготовленої деревини або обсягу заготовленої деревини, тобто цей показник $є$ обернений до фондовіддачі лісових ресурсів.

4. Коефіцієнт використання лісових ресурсів, який відображує загальну площу відновленого лісу на 1 гектар загальної площі рубок лісу. Ми пропонуємо, що цей коефіцієнт повинен дорівнювати одиниці для забезпечення відтворення лісу, щоб через декілька років на місці зрубів виростив ліс. Більшість розрахованих показників неможливо порахувати у вартісних показниках, тому результати обчислень міститимуть такі одиниці виміру як у вартісному виразі (гривні (грн)) такі у натуральному виразі (гектари (га), метр кубічний (м3)). Проведемо аналіз ефективності лісових ресурсів Волинської області за п'ять років, який наведений в таблиці 1.

Таблиця 1

Аналіз ефективності використання лісових ресурсів Волинської області за $2013-2017$ pp.

\begin{tabular}{|c|c|c|c|c|c|c|c|c|c|}
\hline \multirow[b]{2}{*}{ Показники } & \multicolumn{5}{|c|}{ Роки } & \multicolumn{4}{|c|}{ Абсолютне відхилення } \\
\hline & 2013 & 2014 & 2015 & 2016 & 2017 & $\begin{array}{l}2014 / \\
2013 \\
\end{array}$ & $\begin{array}{l}2015 / \\
2014 \\
\end{array}$ & $\begin{array}{l}2016 / \\
2015 \\
\end{array}$ & $\begin{array}{l}2017 / \\
2016 \\
\end{array}$ \\
\hline $\begin{array}{l}\text { Фондовідача, } \\
\text { грн/га }\end{array}$ & 482,44 & 778,84 & 934,64 & 1140,46 & 1291,39 & 296,40 & 155,80 & 205,82 & 150,92 \\
\hline $\begin{array}{l}\text { Фондовідача, } \\
\text { м³ /га }^{3}\end{array}$ & 1,55 & 1,59 & 1,67 & 1,89 & 2,19 & 0,04 & 0,08 & 0,22 & 0,30 \\
\hline $\begin{array}{l}\text { Фондомісткість, } \\
\text { грн/га }\end{array}$ & 0,0021 & 0,0013 & 0,0011 & 0,0009 & 0,0008 & $-0,0008$ & $-0,0002$ & $-0,0002$ & $-0,0001$ \\
\hline $\begin{array}{l}\text { Фондомісткість, } \\
\mathrm{m}^{3} / \text { га }\end{array}$ & 0,65 & 0,63 & 0,60 & 0,53 & 0,46 & $-0,02$ & $-0,03$ & $-0,07$ & $-0,07$ \\
\hline $\begin{array}{l}\text { Продуктивність } \\
\text { лісових ресурсів, } \\
\text { грн/га }\end{array}$ & 8976,00 & 23123,40 & 29373,87 & 32477,55 & 28878,21 & 14147,40 & 6250,47 & 3103,68 & $-3599,35$ \\
\hline $\begin{array}{l}\text { Продуктивність } \\
\text { лісових ресурсів, } \\
\text { м }^{3} / \text { га }\end{array}$ & 28,83 & 47,12 & 52,45 & 53,90 & 49,05 & 18,29 & 5,32 & 1,45 & $-4,85$ \\
\hline $\begin{array}{l}\text { Коефіцієнт } \\
\text { використання } \\
\text { лісових ресурсів }\end{array}$ & 0,11 & 0,19 & 0,24 & 0,22 & 0,20 & 0,08 & 0,05 & $-0,02$ & $-0,02$ \\
\hline
\end{tabular}

авторська розробка

Висновки. За результатами розрахунку запропонованих нами показників фондовіддачі, фондомісткості, продуктивності можна зробити висновок, що в основному використання лісових ресурсів у Волинській області $\epsilon$ ефеективним. 
Однак коефіцієнт відтворення, який показує співвідношення площ посадженого лісу до площ вирубаного - менше 1, тобто вирубаний ліс не засаджується, що через декілька років призведе до зниження ефективності використання біологічних активів лісу. Згідно чинним законодавством, надається два роки для відновлення лісу на місці суцільних зрубів.

\title{
Список використаних джерел:
}

1. Киргизов, Н.Я. (2007). Вопросы методики оценки лесных земель в Казахстанском Алтае. Научные публикации 2007 года. Изьято из http://insles.skom.kz/index.php/kz/nauchnyepublikatsii. [На русском языке]

2. Одношевна, О.О. \& Якубенко, Ю.Л. (2016). Економічний аналіз та оптимізація обліку використання біологічних активів рослинництва. Економічний аналіз, (1, т. 23), 183-188.

3. Сторожук, Т.М. \& Дружинська, Н.С. (2015). Недеревні лісові ресурси. Наук. вісник міжнарод. гуманітар. університету, (10), 161-163.

\section{АНАЛІЗ КОНКУРЕНТНОГО СЕРЕДОВИЩА ЯК ФАКТОР ЗАБЕЗПЕЧЕННЯ КОНКУРЕНТОСПРОМОЖНОСТІ ПІДПРИЄМСТВА}

\begin{abstract}
Волошенко Світлана Володимирівна
асистент кафедри фінансів, обліку та банківської справи Луганський національний університет імені Тараса Шевченка УКРАÏHA
\end{abstract}

На даний момент в Україні відбувається посилення конкуренції, в наслідок чого керівники підприємств знаходяться у постійному пошуку нових (адекватних умовам конкуренції) інструментів управління та важелів підвищення конкурентоспроможності, адже закон конкуренції стверджує, що успішного розвитку та функціонування можуть досягти лише ті підприємства, які мають певні конкурентні переваги.

Теорія конкурентоспроможності суб'єкта підприємницької діяльності та його конкурентних переваг розроблена у працях закордонних вчених: Б. Оліна, Д. Рікардо, А. Сміта, Й. Шумпетера. Вагомий внесок зробили такі науковці, як І.Ансоффф, Ф. Котлер, М. Портер, В. Стівенсон та інші.

Дослідження цієї теми знайшло своє відображення у працях вітчизняних вчених, зокрема, Я. Базилюка, М. Галелюка, Ю. Іванова, О.Кузьміна, О. Чернеги та інших.

Для того, щоб визначити напрями забезпечення конкурентоспроможності підприємства, необхідно визначитись 3 його сутністю. Саме поняття «конкурентоспроможність» багатогранне та, в залежності від об'єкта застосування, має різні трактування. Тому за своєю економічною сутністю конкурентоспроможність підприємства являє собою широку системну категорію, що включає в себе як підсистему конкурентоспроможність товару, 
яка розглядається як передумова та необхідна, але не достатня умова стійких конкурентних позицій підприємства [1].

В межах забезпечення конкурентоспроможності найважливішою економічною категорією $є$ конкурентний потенціал підприємства - сукупність зовнішніх і внутрішніх стосовно до конкурентного середовища можливостей підприємства, реалізація яких створює конкурентні переваги і забезпечує стійку конкурентну позицію на ринку [2].

За А. О. Левицькою конкурентні переваги - сукупність комбінацій наявних у нього ресурсів (сировинних, просторових, трудових, управлінських, технологічних, інформаційних, маркетингових та ін.) та способів їх використання, які забезпечують йому ширші можливості виробництва і реалізації продукції порівняно з його конкурентами [3].

Підвищення конкурентоспроможності становить процес змін, здійснення якого вимагає стратегічного підходу. В основі будь-якої стратегії лежать конкурентні переваги. Виходячи з вищезазначеного, можна стверджувати, що стратегічне управління займається вивченням того, як підприємство може створювати та розвивати конкурентні переваги в умовах підвищеної нестабільності фракторів зовнішнього середовища та їхньої невизначеності.

Аналіз конкуренції можна проводити за допомогою моделі «п'яти сил конкуренції» М. Портера, адже найбільш інтенсивна конкуренція має місце бути між конкурентами у галузі, бо у більшості випадків саме цей параметр у довгостроковому періоді визначає інші. Такий підхід базується на тому, що конкурентну перевагу може бути розглянуто як відносну перевагу суб'єкта господарювання (порівняно з конкурентами) у протидії силам конкуренції: новим конкурентам, товарам-субститутам, постачальникам, споживачам і продавцям (виробникам) конкурентних товарів. Кожен виробник прагне захопити лідерство в конкурентній боротьбі - суперництві на «центральному рингу», використовуючи при цьому індивідуальні підходи й методи. Залежно від обраних дій він може забезпечити собі конкурентну перевагу [1].

Інтенсивність конкуренції являє собою сукупність фракторів, найважливіші серед яких - кількість галузевих організацій та розподіл ринкових часток між ними, темп розвитку ринку, ступінь диференціювання товару, складність виходу з бізнесу.

Оцінку позицій галузевих компаній можливо проводити в залежності від типу галузевої конкуренції (олігополістична чи монополістична), що переважає.

Слід зауважити, що гарне знання конкурентів дозволяє не тільки розробляти міри конкурентної боротьби, а й вести певну узгоджену політику на ринку, оскільки пряма конкуренція завжди має руйнівні наслідки.

Аналіз конкурентної середи та структури конкурентних сил, вивчення конкурентів дають дуже важливу та цінну інформацію для розробки стратегії конкуренції. Але базуючись лише на цих даних, підприємство не зможе розробити стратегії, бо йому також необхідне чітке уявлення свого становища у конкурентному середовищі для формування конкурентних переваг.

Отже, забезпечення конкурентоспроможності підприємства має комплексний характер, а розробці стратегії конкуренції підприємства передує детальний аналіз, з однієї сторони, сильних та слабких сторін діяльності 
підприємства, його позиції на ринку, а з іншої, структури національної економіки в цілому та структури галузі, у якій працює підприємство.

\title{
Список використаних джерел:
}

1. Іванов, Ю. Б., Кизим, М. О., Тищенко, О. М., Іванова, О. Ю., Ревенко, О. В. \& ЧечетоваТерашвілі, Т. М. (2010). Управління конкурентоспроможністю підприємства: Підручник. Харків: ВД «ІНЖЕК». ISBN 978-966-392-289-8.

2. Балабанова, І. В. (2009). Управління конкурентною раціональністю: теорія і методологія. (Автореф. дис. доктора екон. наук). Донецький національний університет економіки і торгівлі імені Михайла Туган-Барановського. Донецьк, Україна.

3. Левицька, А.О. (2012). Конкурентні переваги підприємства: сутність та джерела формування. Вісник Хмельницького національного університету, (4), 51-54.

\section{ВІДКРИТІ ДАНІ ЯК ЗАСІБ СТВОРЕННЯ НОВОЇ ЦІННОСТІ ДЛЯ СУСПІЛЬСТВА}

\begin{abstract}
Івасюк Юрій Олександрович
здобувач освітнього ступеню «Магістр» фракультету економіки, менеджменту та права Вінницький торговельно-економічний інститут КНТЕУ

Науковий керівник: Супрун Світлана Дмитрівна канд. екон. наук, доцент, доцент кафедри економіки та міжнародних відносин Вінницький торговельно-економічний інститут КНТЕУ УКPAÏHA

В Україні активно проводиться політика діджиталізації органів влади, що призводить до відкриття досі закритих даних. Повністю відкритий доступ дозволяє використання їх у різноманітних сферах, від контролю за владними структурами до програмного забезпечення побудованого на їх основі.

У процесі свого зростання і розвитку громади стикаються з різними проблемами вирішення яких створює нові можливості. Для ефрективного вирішення поставлених завдань потрібно пройти три стадії. Дані, які зібрані та доступні для машинної обробки дозволяють проводити аналіз ситуації у режимі реального часу. Після здійснення аналітичної діяльності з даними, отримується інформація, що висвітлює об'єктивну реальність та тенденції розвитку. Наступний етап дозволяє перетворити набуту інформацію на знання, які необхідні для виконання поставлених задач.

У своїй діяльності органи влади в сфері відкритих даних посилаються на постанову Кабінету Міністрів України від 21 жовтня 2015 р. № 835 «Про затвердження Положення про набори даних, які підлягають оприлюдненню у формі відкритих даних», у цій постанові визначаються вимоги до формату і структури наборів даних, що підлягають оприлюдненню у формі відкритих даних, періодичність оновлення та порядок їх оприлюднення, а також перелік таких наборів даних [1]. Контроль за відкриттям доступу до нових наборів
\end{abstract}


даних, які необхідно надавати у відкритий доступ здійснюється також Кабінетом Міністрів України.

Закордонними дослідниками у сфері даних $€$ Т.Бернерс-Лі, Е.Саммерс, А.Лютфі, М. Янссен, вітчизняні наукові напрацювання І.Арістової, В.Брижка, М.Демкова, О.Карпенка, І.Коліушка, Н.Коритнікової, В.Куйбіди, І.Куспляка, Г.Почепцова, А.Серенка та інші.

Надання доступу до наборів даних відбувається у державних підприємств та органів влади з різною швидкістю, відкриття визначених законодавством наборів дозволить зробити владу прозорішою і розширити можливості бізнесу.

За даними порталу відкритих даних (data.gov.ua) виконання постанови 835 Кабінету Міністрів про відкриті дані $€$ державні органи та підприємства, які виконали постанову на $100 \%$, такі як:

- Державна фіскальна служба України;

- Державна казначейська служба України;

- Генеральна прокуратура України;

- Укравтодор;

- M3C;

- Національна рада з питань телебачення і радіомовлення;

- Фонд державного майна.

Стан виконання Постанови - лише 43\%, деякі державні органи не поспішають їх виконувати свою діяльність з надання доступу до відкритих даних:

- Мінкультури;

- Національне агентство із забезпечення якості вищої освіти;

- Міністерство охорони здоров'я України;

- Національне антикорупційне бюро;

- Акціонерне товариство "Національна акціонерна компанія "Нафтогаз України" [2].

При виконанні необхідних дій по викладенню наборів даних необхідно також звертати увагу на якість та можливі

сть машинної обробки. Виконання всіх необхідних дій збільшить швидкість залучення нових розробників до створення інформаційних продуктів на основі відкритих даних.

Таблиця 1

Основні характеристики для вимірювання відкритості даних

\begin{tabular}{|l|l|}
\hline Характеристика & \multicolumn{1}{|c|}{ Пояснення } \\
\hline Доступність & $\begin{array}{l}\text { Дані широко доступні для зацікавлених сторін поза організаційними } \\
\text { межами. }\end{array}$ \\
\hline Вартість & Дані доступні, а економічні бар'єри зменшуються або відсутні. \\
\hline $\begin{array}{l}\text { Юридичні } \\
\text { вимоги }\end{array}$ & $\begin{array}{l}\text { Дані публікуються з відкритими ліцензіями та інші юридичні бар'єри } \\
\text { зменшуються. }\end{array}$ \\
\hline Стандартизація & $\begin{array}{l}\text { Дані, що походять з різних джерел, публікуються за допомогою } \\
\text { стандартних ідентифікаторів, використовуючи відкриті моделі даних. }\end{array}$ \\
\hline $\begin{array}{l}\text { Придатність } \\
\text { для машинної } \\
\text { обробки }\end{array}$ & $\begin{array}{l}\text { Дані точно, своєчасно та послідовно публікуються у машиночитаних } \\
\text { форматах, використовуючи відкриті стандарти з метаданими для } \\
\text { поліпшення зручності використання. }\end{array}$ \\
\hline
\end{tabular}


Продовження табл. 1

\begin{tabular}{|l|l|}
\hline Характеристика & \multicolumn{1}{|c|}{ Пояснення } \\
\hline Відкритість & $\begin{array}{l}\text { Дані або метадані публікуються в центральному сховищі і легко } \\
\text { відкриваються за допомогою веб-пошуку або через посилання на інші } \\
\text { дані (пов'язані дані). }\end{array}$ \\
\hline $\begin{array}{l}\text { Канали для } \\
\text { отримання } \\
\text { інфрормації }\end{array}$ & $\begin{array}{l}\text { Дані публікуються з безліччю безпечних можливостей доступу, } \\
\text { включаючи масове завантаження, веб-сервіси та відкриті АРІ. }\end{array}$ \\
\hline
\end{tabular}

взято з [3]

Важливою є також оцінка міжнародних рейтингів діяльності органів влади.

Рейтинг The Open Data Barometer свідчить про те, що Україна з 2014 - 2017 зростала з 55 місця до 30 відкриттям доступу до даних серед 30 урядів, які прийняли Хартію відкритих даних. Серед оцінок, які надавалися у 2017 році найгірші отримали: картографічні дані (30), дані про власність на землю (5), робота сектору охорони здоров'я (40), та національна статистика навколишнього середовища (25). Готовність до змін у підприємців та урядова політика оцінюється у 52 бали, дії уряду у 70 балів, готовність громадян складає 68 балів, що свідчить про високу зацікавленість усіх сторін [4].

Показником того, що в Україні влада активно сприяє розвитку створення сервісів на основі відкритих даних є конкурс Open Data Challenge переможцям якого надаються кошти на розвиток власних додатків. Уже розроблено понад 25 додатків, які використовують відкриті дані, що надаються органами державної влади. Додатки надають послуги 3 контролю контрагентів; екологічної ситуації у містах; уточнення стану міжнародних повітряних перевезень в Україні; контролювати закупівлі органів влади та підприємств, що надавали їм послуги; пошуку інформації по судовим та іншим реєстрам; оплати штрафів за порушення правил дорожнього руху та багато інших послуг. Розміщуються також на порталі data.gov.ua

Висновки. Відкриті дані у сучасному суспільстві дозволяють створювати нові застосунки, перевіряти якість виконання владними структурами зобов'язань покладених на них, створювати нові можливості для розвитку країни у цілому. Україна зростає у міжнародних рейтингах відкритих даних, що свідчить про проведення необхідних приготувань та прагнення до збільшення прозорості діяльності у владних структурах. Якісне надання інформації формування наборів даних дозволить розширити коло споживачів відкритих даних державних органів. Регулярне проведення конкурсів заохотить увагу до цієї галузі та допоможе розширити співпрацю громадськості та державних структур.

\section{Список використаних джерел:}

1. Про затвердження Положення про набори даних, які підлягають оприлюдненню у формі відкритих даних (Постанова КМУ). Вилучено з https://zakon.rada.gov.ua/laws/main/8352015-\%D0\%BF

2. Єдиний державний веб-портал відкритих даних. (2019). Вилучено 3 https://data.gov.ua/progress

3. Jetzek, T., Avital, M., \& Bjorn-Andersen, N. (2019). The Sustainable Value of Open Government Data. Journal of the Association for Information Systems, 20 (6).

4. The Open Data Barometer. (2017). Вилучено 3 https://opendatabarometer.org/countrydetail/?_year=2017\&indicator=ODB\&detail=UKR 


\title{
ВЛИЯНИЕ СТРУКТУРЫ ФАРМАЦЕВТИЧЕСКОГО РЫНКА И РЫНКА УСЛУГ КЛИНИЧЕСКИХ ИССЛЕДОВАНИЙ РОССИИ НА ВЫБОР СТРАТЕГИЧЕСКИХ НАПРАВЛЕНИЙ РАЗВИТИЯ ЛОКАЛЬНОЙ КОНТРАКТНОЙ ИССЛЕДОВАТЕЛЬСКОЙ ОРГАНИЗАЦИИ
}

\begin{abstract}
Аронова Елена Владимировна
магистрант Института экономики и управления Федеральное государственное автономное образовательное учреждение высшего образования «Белгородский государственный национальный исследовательский университет»

Научный руководитель: Прядко С.Н. кандидат экономических наук, старший преподаватель кафедры менеджмента и маркетинга Федеральное государственное автономное образовательное учреждение высшего образования «Белгородский государственный национальный исследовательский университет» РОССИЙСКАЯ ФЕДЕРАЦИЯ
\end{abstract}

Российский рынок демонстрирует устойчивую тенденцию к росту $[6,7,8]$. В 2018 году темпы роста замедлились, в связи с рядом факторов, среди которых государственное регулирование отрасли, состояние экономики России и снижением платежеспособности населения. Тем не менее, в 2018 году российский фрармацевтический рынок в долларовом выражении занял 16-е место в мире [6].

Особенностью российского фрармацевтического рынка является соотношение долей оригинальных препаратов и воспроизведенных (дженериков). В 2017 году в России на дженерики приходилось 88\% доли рынка в натуральном выражении (в упаковках), в то время как в Нидерландах - $72 \%$, в Финляндии - 42\%, во Франции - 30\%, а в Италии - 19\% [8].

Преобладание дженериков на российском рынке означает, что на рынке услуг клинических исследований фармацевтическими компаниями, прежде всего, востребованы доклинические исследования и исследования биоэквивалентности.

Это подтверждается анализом ежегодных бюллетеней Ассоциации по клиническим исследованиям. Если проследить динамику обращения фармацевтических компаний за услугами контрактных исследовательских организаций (КИО), то можно увидеть, что как отечественные, так и иностранные компании все чаще передают исследования биоэквивалентности на аутсорсинг российским КИО: 16\% в 2014 году и 27\% в 2018 году для иностранных компаний; 7\% в 2014 году и 14\% в 2018 году для российских компаний [1,2,3,4,5]. 
С аутсорсингом других видов клинических исследований ситуация принципиально иная. Международные многоцентровые клинические исследования спонсируются крупными иностранными фармацевтическими компаниями. Как правило, такие проекты отдаются на аутсорсинг крупным международным КИО, выбор совершается на уровне зарубежных штабквартир, поэтому локальная российская КИО не сможет конкурировать с глобальными КИО [1,5].

Что касается локальных клинических исследований, проводимых в России иностранными фармацевтическими компаниями с целью последующей регистрации лекарственного средства и вывода на российский рынок, то динамика отрицательная. В 2014 году 23\% таких проектов были переданы на аутсорсинг российским КИО, а в 2018 году только 11\%. Российские фармацевтические компании передают свои локальные клинические исследования на аутсорсинг в 18\% случаев, как в 2014, так и в 2018 годах $[1,2,3,4,5]$.

Исходя из структуры рынка, можно сделать вывод, что локальной КИО приоритетным направлением целесообразно рассмотреть бизнес услуг доклинических исследований и исследований биоэквивалентности.

Бизнес услуг доклинических исследований и биоэквивалентности можно вести в двух форматах. Первый - организация лаборатории, в которой непосредственно проводятся работы с животными и пациентами. Второй посредничество, когда КИО получает от фармацевтической компании заказ на проведение работ и, в свою очередь, переадресовывает заказ лаборатории как субподрядчику. В первом случае маржинальность будет выше, потому что заказы выполняются силами штатного персонала на собственном оборудовании организации. Во втором случае маржинальность будет ниже, в связи с использованием субподряда. С целью повышения маржинальности одним из возможных вариантов является привлечение инвестора для создания собственной лаборатории.

\section{Список использованных источников:}

1. Ассоциация организаций по клиническим исследованиям. (2015). Информационноаналитический бюллетень №10. Изъято из http://acto-russia.org/files/bulletin_10.pdf

2. Ассоциация организаций по клиническим исследованиям. (2016). Информационноаналитический бюллетень №12. Изъято из http://acto-russia.org/files/bulletin_12.pdf

3. Ассоциация организаций по клиническим исследованиям. (2017) Информационноаналитический бюллетень №14, итоги 2016 г. http://acto-russia.org/files/bulletin_14.pdf (2019, ноябрь, 20)

5. Ассоциация организаций по клиническим исследованиям. (2018) Информационноаналитический бюллетень №16, итоги 2017 г. http://acto-russia.org/files/bulletin_16.pdf (2019, ноябрь, 20)

6. Ассоциация организаций по клиническим исследованиям. (2019) Информационноаналитический бюллетень №18, итоги 2018 г. http://acto-russia.org/files/bulletin_18.pdf (2019, ноябрь, 20)

7. Исследовательский центр компании «Делойт» в СНГ. (2019) Государственное регулирование: барьеры или стимулы для развития рынка. тенденции фармацевтического 
рынка России. https://www2.deloitte.com/content/dam/Deloitte/ru/Documents/life-scienceshealth-care/russian/russian-pharmaceutical-market-trends-2019.pdf (2019, ноябрь, 20)

8. Российская ассоциация венчурного инвестирования. (2018) Обзор рынка. Прямые и венчурные инвестиции России 2018. http://www.rvca.ru/download.php?file=upload/files/lib/RVCA-yearbook-2018-Russian-PE-andVC-market-review-ru.pdf (2019, ноябрь, 18)

9. Улумбекова Г.Э., Калашникова А.В. (2018) Подходы к формированию концепции национальной лекарственной политики. Часть 1. Анализ рынка лекарственных препаратов в РФ. Вестник ВШОУЗ, № 4 (14), 54-75.

\title{
ВПЛИВ ОБЛІКУ І ВНУТРІШНЬОГО КОНТРОЛЮ НА ФОРМУВАННЯ АМОРТИЗАЦІЙНОЇ ПОЛІТИКИ ПІДПРИЕМСТВА
}

\begin{abstract}
Слєсар Тетяна Миколаївна
кандидат економічних наук

Національний університет біоресурсів і природокористування України

Черненко Анна Олегівна

здобувач вищої освіти

Національний університет біоресурсів і природокористування України
\end{abstract}

УКРАÏHA

Перед українською економікою тривалий період стоїть проблема пошуку фінансових ресурсів для здійснення інвестиційної діяльності. Але одне 3 найважливіших джерел інвестицій в основні засоби - амортизаційні відрахування недостатньо задіяне в даному процесі. I така ситуація $€$ не лише проблемою бухгалтерського обліку. Пошук фрінансування своєчасного оновлення виробничих засобів підприємства залежить не від бухгалтерської служби. Потрібно вирішувати питання методології процесу нарахування амортизації в цілому.

Пошуку ефективних шляхів фрормування амортизаційної політики та розгляду суті і ролі амортизації, присвячені праці таких вчених, як Брошенко О.В., Власюк Т. М. [1], Гавриловський О.С. [2], Гудзь О.Є., Олійник О.В., Партин Г.О., Правдюк О.Л., Проданчук М.А., Чорнявська Т.М., Щирська О.В. [3] та ряд інших.

Основною перешкодою формування достатнього обсягу амортизаційних відрахувань підприємства $є$ незахищеність і практична безконтрольність саме цієї статті витрат. Контроль своєчасного і достовірного нарахування амортизації здійснюється лише під час перевірки сум податку на прибуток.

Внутрішній контроль ефективності використання основних засобів, правильність вибору методів нарахування амортизації та напрямки використання акумульованих коштів забезпечують раціональне управління 
ризиками та надають можливість вичерпного інформативного забезпечення розрахунку оптимальних напрямків стратегічного розвитку підприємства.

Під внутрішнім контролем амортизації основних засобів слід розуміти процес виявлення відхилень, зловживань і безгосподарності, а також усунення та попередження їх появи у майбутньому. Причому даний контроль організовується власником, а здійснюється здебільшого бухгалтерською службою, що викликає конфлікт інтересів, тому, на підприємствах для цілей управління необхідно створювати окремі підрозділи (відділи) внутрішнього контролю.

Метою внутрішнього контролю являється не лише уточнення правильності відображення амортизації основних засобів на рахунках бухгалтерського обліку. Необхідність здійснення контролю за амортизацією основних засобів посилюється ще у зв'язку з тим, що від визначення розміру амортизації залежить обсяг прибутку, який $€$ внутрішнім джерелом фрінансування підприємства, а отже нехтувати ними неварто.

Для ефективного функціонування системи внутрішнього контролю амортизації основних засобів необхідною $є$ ії належна організація та чітке розмежування за окремими елементами, що дає змогу обґрунтувати етапи їі проведення та визначити необхідність застосування тих чи інших контрольних заходів на різних етапах.

Амортизаційна політика впливає на ефективність суспільного виробництва, впливаючи на процес оновлення основних засобів, прискорення темпів науково-технічного прогресу, інвестиційної діяльності. В ході дослідження складу операційних витрат більшості підприємств визначено, що саме амортизаційні відрахування та частина витрат, яка є найбільш вразливою при збитковій діяльності підприємства, адже дотримання термінів виплати і сум оплати праці з нарахуваннями, своєчасну оплату за матеріальні ресурси контролюють ззовні, а дотримання порядку амортизаційних відрахувань підприємства підлягає тільки внутрішньому контролю.

Правильна організація і побудова бухгалтерського обліку формування амортизаційних накопичень має велике значення, так як забезпечує швидке відшкодування вартості основного засобу.

Щирська О.В. [3] наголошує, що «проблеми обліку амортизації $\epsilon$ предметом особливої уваги економічної науки, оскільки амортизація одночасно є витратами виробництва та джерелами відтворення і, як наслідок, впливає на широке коло економічних показників: собівартість, ціну, прибуток, податки, кількісні та якісні оцінки ринкової вартості підприємства. При цьому їі актуальність обумовлена, в першу чергу, існуванням значної кількості невирішених проблемних питань, що час від часу з'являються із прийняттям чергових недосконалих нормативно-правових актів».

У зв'язку з тим, що амортизаційна політика $€$ складовою частиною облікової політики, вона спрямована на підвищення ефективності виробництва та піднесення результатів діяльності організації. Амортизаційна політика у кожному конкретному випадку потребує певних коригувань в залежності від певної ситуації і економічної стратегії на перспективу. Вона являється потужним важелем впливу на економічні процеси, що відбуваються. 
Для цілісної картини зміни методики нарахування амортизації необхідні додаткові заходи контролю за наявністю реальних амортизаційних накопичень із залученням контролюючих державних органів.

\section{Список використаних джерел:}

1. Власюк, Т. М. \& Юзюк, І. І. (2014). Основні засоби: організаційно-методичні аспекти формування облікової політики підприємства, Київ: Вісник КНУТД, (2), 197-206.

2. Гавриловський, О. С. \& Лук'яненко, Л. І. (2015). Основні шляхи розвитку та вдосконалення амортизаційної політики в Україні, Економічний аналіз: зб. наук. праць Тернопільський національний економічний університет. 22(1), 164-168. Тернопіль: Економічна думка.

3. Щирська, О. В. (2011). Питання обліку амортизації в різних літературних джерелах, Проблеми теорії та методології бухгалтерського обліку, контролю і аналізу, 3(21), Ч. II, 410-415.

\section{ЕЛЕКТРОННА КОМЕРЦІЯ ЯК СУЧАСНА ФОРМА ОРГАНІЗАЦІЇ БІЗНЕСУ}

Яремко Максим Олександрович

здобувач вищої освіти факультету економіки, менеджменту та права Вінницький торговельно-економічний інститут КНТЕУ

Лозовський Олександр Миколайович канд. екон. наук, доцент, доцент кафедри менеджменту та адміністрування Вінницький торговельно-економічний інститут КНТЕУ

УКРАÏHA

В сучасних умовах господарювання особливу роль у організації бізнеспроцесів відіграє електронна комерція. Сучасне суспільство, оточене інформаційно-комунікаційними технологіями, прагне розвитку нової сфери товарно-грошових відносин, яка відбувається у мережі Інтернет. Здійснюючи комерційну діяльність онлайн, фрірми мають набагато більше шансів залишатись конкурентоспроможними на ринку ніж ті, хто використовує лише традиційні методи ведення бізнесу.

Особливості електронної комерції в умовах сьогодення вивчали провідні вітчизняні та іноземні науковці. Теоретичні основи електронної комерції досліджували та продовжують вивчати такі відомі фахівці, як: Маловичко С.В., Марусей Т.В., Полях В.М., Клочко В.М., Шалева О. І. Гармідер Л.Д., Орлова А.В., Палеха Ю. І., Горбань Ю. І., Чуйко Н.В., Шарапова О.М. та інші. Вони визначали сутність даного поняття, а також описали процес розвитку електронної комерції як напрямку інформаційного бізнесу, що швидкими темпами розвивається у сучасному глобалізаційному світі.

Для того, щоб зрозуміти сутність поняття «електронна комерція», важливо зосередити увагу на її основних видах, відповідно до сегменту споживачів:

- «бізнес для бізнесу», суть якого полягає у наданні певної послуги одним видом бізнесу іншому. Інтернет у цьому випадку допомагає оптимізувати інформаційні процеси та проводити їх прозоро; 
- «бізнес для клієнта», приклад - продаж товарів фрізичним особам;

- «споживач споживачеві», що припускає відносини між неділовими людьми, наприклад у форматі Інтернет-аукціонів;

- «бізнес для адміністрації», що характеризує відносини підприємця 3 певними управлінськими структурами; прикладом може бути проведення тендеру;

- «клієнт для адміністрації», полягає у взаємодії між державними структурами та споживачами певних видів послуг.

Виокремимо основні функції електронної комерції:

- реклама;

- демонстрація товару;

- здійснення операцій;

- післяпродажне обслуговування;

- налагодження довгострокових відносин з клієнтом.

Основні функції електронної комерції вказують на те, що така форма організації бізнесу є ерективним способом заохочення уваги споживача до товару; дозволяє здійснити швидкі та безпечні розрахунки; передбачає допомогу клієнту у процесі покупки та післяпродажного обслуговування, а також має довгострокову перспективу, що передбачає вивчення переваг i смаків клієнтів.

Аналізуючи основні тенденції вітчизняного ринку електронної комерції, відзначимо наступних лідерів: Rozetka, Алло, Fotos, Mobilluck, Фокстрот, Fotomag, Deshevshe, Comfy, Citrus, Ельдорадо, Sokol, Фоксмарт. Найбільш значним за показником обігу у 2018 році є сегмент електроніки та побутової техніки (близько 1 млрд. дол.) [2].

Маркетингові дослідження ринку електронної торгівлі в Україні відзначають, що споживачі віддають перевагу придбанню через Інтернет товарів побутової техніки середньої цінової категорії. Середній розмір однієї покупки даної категорії товарів через мережу Інтернет варіюється в межах 200 доларів. Однак варто зазначити, що протягом останніх років спостерігається тенденція до збільшення вартості товарів, проданих онлайн, в той час як кількість дрібних продажів зменшується [3].

Основну частину Інтернет-покупців становлять люди у віці від 14 до 34 років, з яких $36 \%$ - жителі міст з населенням понад 500000 чоловік, 20,5\% проживають в сільській місцевості [2]. Найчастіше українці купують взуття, одяг, аксесуари, мобільні телефони, техніку й електроніку, товари для дому та саду. Важливим фрактором, який позитивно впливає на зростання аудиторії онлайн-покупців, $€$ поширення доступу до $3 G$. Особливо помітно це стане протягом найближчих років.

Основними перевагами впровадження електронної комерції вітчизняних підприємств слід вважати: широкий масштаб охоплення території (власник Інтернет-магазину завжди має більше клієнтів); можливість швидкого введення товару на ринок; персоналізація; широкий асортимент і доступніші ціни, ніж в магазинах; оптимізація бізнес-процесів; на відкриття онлайнмагазину потрібно менше фінансових вкладень; економія коштів на оренду приміщення та заробітну плату персоналу тощо.

Серед негативних аспектів впровадження електронної комерції на українському ринку слід відзначити: недосконалість законодавчого 
регулювання бізнесу в Інтернеті; фрактор «недовіри» певного сегменту споживачів; внаслідок відкритості інформації зростає ймовірність порушення прав інтелектуальної власності, плагіату, фрінансових шахрайств, тому постає проблема інформаційної безпеки; монополізація ринків, оскільки сектор малого підприємництва не завжди може вистояти перед викликами конкурентного середовища [4]. Також електронна торгівля не користується попитом серед підприємців, що займаються продажем продуктів харчування, адже їх населення обирає купувати традиційним способом - у магазинах.

Отже, електронна комерція на вітчизняному ринку розвивається значними темпами та має беззаперечні переваги, насамперед пов'язані з зменшенням витрат на інфраструктуру бізнесу, а також швидким інформуванням клієнтів та можливістю цілодобового обслуговування. За останні роки в Україні спостерігають позитивні тенденції розвитку ринку електронної торгівлі, а тому дана форма організації бізнесу $є$ перспективною та допомагає суспільству перейти на новий етап розвитку товарно-грошових відносин.

\title{
Список використаних джерел:
}

1. Васильєв Ю.Ю. Електронна комерція як інструмент просування товарів на ринку побутової техніки. Міжнародний науковий журнал «Інтернаука».2017. №1 (23), 2 т. С.29-34.

2. Маловичко С.В. Аналіз сучасних тенденцій та динаміки розвитку електронної торгівлі на підприємствах України. Проблеми економіки. 2015. № 2. С. 71-77.

3. Марусей Т.В. Основні тенденції розвитку ринку електронної комерції в Україні. Економіка $i$ суспільство. 2018. № 14. С. 1011-1015.

4. Полях В.М., Кривошеєва Н.М., Клочко В.М., Шарапова О.М., Чуйко Н.В. Електронна комерція: теоретико-правові засади та сучасний стан в Україні. Scientific Journal «ScienceRise». 2017. №5(34). C. 11-17.

\section{ЕТАПИ КАМЕРАЛЬНОЇ ПЕРЕВІРКИ ДЕКЛАРАЦІЇ 3 ПДВ}

\author{
Гайсенок Вікторія Володимирівна \\ здобувач вищої освіти економічного фракультету \\ Запорізький національний університет \\ Науковий керівник: Саєнко Олена Романівна \\ канд. екон. наук, доцент кафедри обліку та оподаткування \\ Запорізький національний університет \\ УКРАÏHA
}

Будь-яка перевірка на підприємстві - це певний ризик. Податкова перевірка - вид податкового контролю, і якщо вже надійшов «дзвінок» можна зробити висновок що, щось зроблено не так. Перевірок буває декілька видів, і серед них камеральну можна назвати першою у списку. Ї̈̈ не слід боятися, просто треба знати, як правильно діяти, а потім виправити помилки.

Камеральною вважається перевірка, яка проводять у приміщенні контролюючого органу повністю на підставі даних, зазначених у податкових деклараціях платника податків та даних системи електронного 
адміністрування податку на додану вартість, а також даних Єдиного реєстру акцизних накладних та даних системи електронного адміністрування реалізації пального.

Таблиця 1

Основні етапи перевірки декларації з ПДВ

\begin{tabular}{|c|c|c|c|}
\hline \multicolumn{2}{|c|}{ Візуальний контроль } & \multicolumn{2}{|c|}{ Арифметичні та методологічні помилки } \\
\hline Реквізити & Терміни подання & Арифметичні помилки & Методологічні помилки \\
\hline $\begin{array}{l}\text { Податкова } \\
\text { декларація повинна } \\
\text { містити всі } \\
\text { реквізити, } \\
\text { передбачені ст. } 48 \\
\text { ПКУ, та бути } \\
\text { складеною за } \\
\text { формою, чинною на } \\
\text { момент подання, } \\
\text { затвердженою в } \\
\text { порядку п. } 46.5 \text { ПкУ. } \\
\text { Якщо у декларації } \\
\text { не зазначено будь- } \\
\text { якого з обов'язкових } \\
\text { реквізитів, вона } \\
\text { втрачає свій статус } \\
\text { та не визнається } \\
\text { поданою. }\end{array}$ & $\begin{array}{l}\text { Один із головних } \\
\text { чинників, через } \\
\text { невідповідність } \\
\text { якому декларація } \\
\text { не пройде } \\
\text { камеральну } \\
\text { перевірку на } \\
\text { початковій стадії. } \\
\text { У разі порушення } \\
\text { терміну подання } \\
\text { декларації } \\
\text { складається } \\
\text { відповідний акт, і } \\
\text { саме за } \\
\text { результатами } \\
\text { камеральної } \\
\text { перевірки } \\
\text { застосовується } \\
\text { штрафф згідно зі } \\
\text { ст. } 120 \text { ПкУ. }\end{array}$ & $\begin{array}{l}\text { Помилковий запис, } \\
\text { помилки в обчисленні, } \\
\text { неправильне } \\
\text { перенесення даних із } \\
\text { додатків до } \\
\text { декларації, } \\
\text { неправильно } \\
\text { проставлена кома в } \\
\text { цифрових показниках } \\
\text { тощо }\end{array}$ & $\begin{array}{l}\text { Неправильне } \\
\text { застосування ставок } \\
\text { податку, коефіцієнтів, } \\
\text { неправильне тлумачення } \\
\text { порядку заповнення і, як } \\
\text { наслідок, дані вписані не } \\
\text { в ті рядки, графи, } \\
\text { додатки. }\end{array}$ \\
\hline
\end{tabular}

дані сфрормовано з [1]

Висновок. Усі ці помилки і виявляються під час камеральної перевірки, яка охоплює всю звітність - як ту, що надходить у паперовому вигляді, так $\mathrm{i}$ електронну. Крім цього, під обов'язкову камеральну перевірку потрапляють усі уточнюючі розрахунки. Результати такої перевірки можуть стати приводом для запиту щодо надання певних пояснень, документів і навіть до наступних перевірок інших видів.

\section{Список використаних джерел:}

1. Податковий кодекс України. №2755-VI. (2019). Вилучено 3 https://zakon.rada.gov.ua/laws/main/2755-17

2. Камеральна перевірка. Вилучено з https://www.golovbukh.ua/article/7460-kameralnaperevrka 


\section{ЗАХОДИ ІЗ ЗАБЕЗПЕЧЕННЯ КОНКУРЕНТНИХ ПЕРЕВАГ ОНЛАЙН-РИТЕЙЛУ}

\section{НАУКОВО-ДОСЛІДНА ГРУПА:}

Чміль Ганна Леонідівна

канд. екон. наук, доцент, доцент кафедри маркетингу і комерційної діяльності Харківський державний університет харчування та торгівлі

Олініченко Катерина Сергіївна канд. екон. наук, доцент, доцент кафедри маркетингу і комерційної діяльності Харківський державний університет харчування та торгівлі

Мороз Тетяна Борисівна здобувач вищої освіти економічного факультету Харківський державний університет харчування та торгівлі

УКРАÏHA

Глобальні трансформації в економічному та культурному просторі, викликані цифровою революцією, позначились на всіх сферах суспільного виробництва, суттєво змінивши конфігурацію ринкового середовища та поведінку економічних суб'єктів. Зміни спрямованості стратегічних векторів конкурентної боротьби у напрямку стратегії голубого океану, ціннісної конкуренції та маркетингу 3.0 відбилися на організаційній поведінці підприємницького сектора, а технологічні інновації визначили ключові тренди останнього десятиліття у продуктовій, ціновій, комунікаційній та збутовій політиках підприємств, а також поведінкових патернах покупців та продавців на ринку онлайн-ритейлу. У фрокусі сучасних клієнт орієнтованих конкурентних стратегій операторів мережної торгівлі постає людина, що спонукає фрірми відстежувати історію їх покупок, щоб персоналізувати власні послуги і конкурентні переваги та спілкуватися з покупцями через зручні комунікаційні канали соціальних мереж. 3 огляду на глобальний характер та перспективність електронного бізнесу актуальним $€$ визначення заходів із забезпечення конкурентних переваг онлайн-ритейлу.

Сьогодні, продавці повинні використовувати безліч інноваційних інструментів, щоб взаємодіяти зі споживачем у реальному часі. Основним завданням такої взаємодії $€$ організація Інтернет-реклами, розширення присутності власного бренду онлайн з метою залучення максимально широкої аудиторії, збільшення пошукових запитів за конкретним брендом і кількості відвідувань веб-сайту. Вирішують це завдання оператори через: оптимізацію Лендінг-сторінки в онлайн і мобільному сегменті; розміщення торговельної марки в соціальних мережах та на всіх популярних платформах; використання оплачених сервісів для зручності та поширення можливостей пошуку товарів, тобто так звану SEO-оптимізацію сайту (англ. search engine optimization), його «розкручування», «просування»; застосування краудтехнологій (оптимальних інструментів управління рішенням споживачів); таргетинг та ретаргетинг.

Практичний досвід реалізації інноваційних рішень, які використовують суб'єкти електронного ритейлу, і які є визначними драйверами стратегій 
їх розвитку, що спрямовані на підвищення рівня якості обслуговування та поліпшення задоволення потреб споживачів, зазвичай розподіляють за видами транзакцій на три групи: фрінансові; торговельні та комунікаційні; логістичні [1].

Щодо реалізації фрінансових транзакцій, то їх ефективність залежить від специфріки систем взаєморозрахунків, які являють собою сукупність платіжних засобів, способів оплати, використання платіжних інструментів, до яких належать платежі при доставці товару готівкою, а також електронні розрахунки (банківські переводи, платіжні картки, смарт-картки, інтернетбанкінг, мобільний банкінг, розрахунки в платіжних терміналах торговосервісних підприємств, а також в мережі Інтернет, електронні гроші, електронні чеки та ін. на ринку платіжних систем України) [2].

Вдала реалізація торговельних та комунікаційних транзакцій залежить це перш за все від правильно обраної безпечної серверної платформи, надійності послуг Інтернет-провайдера та використаних програмних продуктів, що дозволяє запобігти низки певних технічних проблем, і забезпечується чіткою організацією торговельно-технологічого процесу 3 конкретною інформаційною підтримкою в Інтернеті через: електронні представництва сайти, Web-вітрини, Web-каталоги, які несуть важливе інформаційне та рекламне навантаження і формують подальшу емоційно-психологічну поведінку покупця; систему інтерфейсу, яка дозволяє легко отримати повну та достовірну інформацію про товари; рейтингове порівняння ідентичних товарів за різними критеріями; наявність електронного кошику, що регулює запаси ритейлора синхронно з заповненням покупцем форми заказу в онлайні.

Третя група транзакцій пов'язана з вчасним та якісним матеріальним забезпеченням дистанційних торговельних угод, тобто організацією логістичних потоків, яке не є одноразовою роботою, а потребує постійної уваги та модернізації. Логістичні транзакції пов'язані з управлінням ланцюгом постачання товарів та складським обліком для його забезпечення. У цьому напрямку $є$ свої особливості в українському електронному ритейлі. Наразі в електронному ритейлі пропонують доставку товарів споживачу декількома способами: самовивозом, кур'єрською доставкою власним кур'єром або кур'єрськими компаніями, поштовим перевізником. Розвиваються й такі інноваційні форми постачання, як автоматизовані служби доставки (поштомати). При цьому важливими технологіями $є$ штрих-кодування, QRкодування та інші технології, які дають можливість обміну даними. Під час організації постачання онлайн-ритейлери орієнтуються на налагоджений процес доставки в регіони, зменшення витрат при вчасній доставці товарів, зручні сервіси і тарифи, які надають приватні поштово-логістичні компанії, підвищення надійності обслуговування замовників, покращення в цілому економічних показників діяльності підприємства.

Визначені драйвери стратегії розвитку онлайн-ритейлу здебільшого орієнтовані на підвищення рівня якості обслуговування та поліпшення задоволення потреб споживачів. Для того щоб знайти унікальну стратегію для інтернет-магазину і домогтися істотних результатів слід також обирати оптимальні варіанти збільшення метрик, що впливають на LTV. 


\section{Список використаних джерел:}

1. Авдеев, А. (2013). Тенденции развития электронной коммерции в Украине: статистика, тренды, проблемы. Тренды в интернет маркетинге. Извлечено из: http://netpeak.ua/files/books/trends_2013.pdf.

2. Савицька, Н.Л. (2014). Драйвери та бар'єри розвитку онлайн-ритейлу: теоретикометодичний аспект. Бізнес Інформ, (10), 236-241.

\section{ІНФРАСТРУКТУРА ЯК ОДИН ІЗ ВАЖЛИВИХ ЧИННИКІВ РОЗВИТКУ ТУРИЗМУ В УКРАЇНІ}

Кушніренко Олександра Олегівна

Вінницький торговельно-економічний інститут КНТЕУ

Малюта Катерина Геннадіївна

асистент кафедри туризму та готельно-ресторанної справи

Вінницький торговельно-економічний інститут КНТЕУ

УКРАÏHA

В умовах ринкових форм господарювання проблема фрормування ефективної ринкової інфраструктури туризму $є$ надзвичайно актуальною для України. Ефективно діюча сучасна туристична інфраструктура $є$ важливим чинником формування конкурентоспроможної вітчизняної туристичної галузі у світовому розподілу праці. Інфраструктуру туризму можна розглядати як комплекс видів діяльності щодо створення умов для реалізації туристських послуг і як сукупність різноманітних об'єктів, що використовуються для задоволення потреб туристів. Саме сприяння задоволенню туристських потреб та можливості здійснити необхідні споживчі витрати туристом і повинно стати головною метою розвитку туристичної інфрраструктури [2].

Туристичні об'єкти в Україні залишаються незатребуваними через нерозвиненість інфраструктури туристичних послуг, недосконалості механізмів державного регулювання на різних рівнях влади, відсутність мотивації для приватних інвестицій у туристичні ринки та ефективних методів економічного аналізу туристичного комплексу регіонів [4].

Наявність саме розвиненої туристичної інфраструктури у багатьох випадках $є$ визначальним фактором, що впливає на вибір споживачем місця призначення при наявності певної мети відпочинку.

Особливого значення набуває адаптація вітчизняної туристичної інфраструктури до міжнародних вимог щодо маркування, оцінки відповідності категоріям, складу обов'язкових послуг та якості обслуговування, тобто приведення об'єктів інфрраструктури (готелі, ресторани, кафее, культурні заклади, магазини, спортивні майданчики, ігрові майданчики, об'єкти побутового обслуговування тощо) до вимог певного рівня, який буде зрозумілий для туриста та буде відповідати його очікуванням [3].

Україна має розвинуту мережу автомобільних доріг і залізниць, аеропортів, річкових і морських портів. Авіаційний, автомобільний, залізничний, річковий і морський транспорт здатні забезпечити перевезення туристів з резервом транспортних потужностей на деяких видах транспорту. Саме тому, 
транспортні шляхи України повинні відповідати міжнародним вимогам та надавати можливість здійснювати перевезення швидко, безпечно, надійно і комфортно. В Україні прийнята Програма функціонування національної мережі міжнародних транспортних коридорів, її реалізація дозволить розв'язати проблему облаштування доріг, створити сприятливі умови для розвитку туристичної індустрії. Не менш важливою складовою інфраструктури $€$ існуюча мережа прикордонних переходів із країнами-сусідами, її розширення та сервісне облаштування. Неможливий розвиток туризму без системи зв'язку і комунікацій, фрункціонування різноманітних служб сервісу, розвитку громадського харчування і побутового обслуговування, організації культурнорозважального обслуговування. Актуальною для України залишається проблема водопостачання та каналізації населених пунктів і, в першу чергу, рекреаційних центрів. Проблема інфраструктурного облаштування території України може бути вирішена лише завдяки інвестуванню в їі розбудову великих коштів, в тому числі з боку центральної та місцевих влад, їі розв'язання можливе лише в контексті практичних дій по економічному піднесенню країни [1].

Отже, інфраструктура ринку туристичних послуг одночасно виконує роль каталізатора, що значно активізує туристичний попит, а також, значною мірою, визначає рівень конкурентоспроможності туристичного продукту [3].

\section{Список використаних джерел:}

1. Кифяк, В. Ф. (2003). Організація туристичної діяльності в Україні. Чернівці: Політехніка.

2. Кривега, К. В (2005). Туристична інфраструктура: поняття та складові. Гуманітарний вісник ЗДІА, (№21), 118-121. Вилучено з http://nbuv.gov.ua/UJRN/znpgvzdia_2005_21_13.

3. Лендєл, О.Д. (2018). Напрямки розвитку інфраструктури ринку туристичних послуг регіону. Науковий вісник Мукачівського державного університету. Серія "Економіка", 1(9), 111-114. Вилучено з https://msu.edu.ua/visn/?p=3426\&amp;lang=uk.

4. Хаустова, В. Є. \& Горбатова, Є. Ф. (2010). Проблеми розвитку туристичної галузі в Україні. Проблеми економіки, (2), 30. Вилучено з http://problecon.com/.

\section{МАКРОПРУДЕНЦІЙНА ПОЛІТИКИ НАЦІОНАЛЬНОГО БАНКУ УКРАЇНИ}

Андрющенко Ірина Сергіївна канд. екон. наук, доцент кафедри фінансів, аналізу та страхування Харківський державний університет харчування та торгівлі УКРАÏHA

В Україні проблема збереження фінансової стабільності стоїть особливо гостро. За частотою системних банківських криз країна входить до світової трійки лідерів. Протягом останніх 20 років вона пройшла через три глибокі фінансові кризи, остання трапилася у 2014-2016 рр. Прямі фіскальні витрати на подолання її наслідків становили $15,7 \%$ від ВВП відповідних років - це помірна величина порівняно з іншими країнами. Водночас прямі втрати всієї економіки становили понад $38 \%$ від ВВП. Наслідки цієї системної кризи ще 
довго обмежуватимуть банківське кредитування та економічне зростання.

Відповідно до статті 6 Закону України «Про Національний банк України» [1], НБУ в межах своїх повноважень сприяє фінансовій стабільності, у тому числі стабільності банківської системи за умови, що це не перешкоджає досягненню цінової стабільності. По суті, Закон закріплює за НБУ мандат на розроблення та впровадження макропруденційної політики.

Макропруденційна політика - це політика, спрямована на упередження накопичення та реалізації системних ризиків у фінансовому секторі, а також підвищення його стійкості [2]. Процес проведення макропруденційної політики складається з чотирьох етапів [3]:

І етап. Виявлення системних ризиків. На цьому етапі проводиться аналіз стану ключових ринків на основі відкритих статистичних даних, а також інформації від підрозділів НБУ, зокрема відповідальних за банківський нагляд, монетарну політику, оверсайт платіжних систем, операції на відкритому ринку. Також беруться до уваги думки інших регуляторів фінансового сектору. Для виявлення ризиків використовуються кількісні індикатори та експертні судження, зокрема такі:

- макроекономічна, грошово-кредитна, банківська статистика, показники фінансового, реального секторів та ринку нерухомості;

- показники платоспроможності фрінансово-промислових груп найбільших позичальників українських банків, сектору домогосподарств;

- опитування банків та інших учасників фінансового ринку.

II етап. Вибір та калібрування інструментів. НБУ вибирає такий макропруденційний інструмент, який найбільше відповідає виявленому системному ризикові. У процесі вибору макропруденційних інструментів НБУ враховує такі фрактори: масштаб системного ризику (стосується всього сектору чи його частини), його походження (від позичальників чи кредиторів), спосіб дії інструментів (вплив на активи/пасиви банку або на його поведінку на ринку), їх вплив на фрінансовий цикл (стримування зростання чи обмеження падіння), наявність побічних/небажаних ефектів їх дії. Далі відбувається їхнє узгодження з іншими видами політики НБУ та калібрування відповідно до масштабу та зони поширення ризику, умов та перспектив розвитку фінансового сектору. Інструменти мають бути завчасно визначені та відкалібровані на випадок необхідності їх активації. У своєму виборі НБУ орієнтується на базовий перелік інструментів, запропонований ESRB, але за потреби може використовувати й інші макропруденційні заходи, зокрема для нівелювання ризиків, характерних суто для українського банківського сектору.

III етап. Макропруденційне реагування. Залежно від ситуації НБУ може реагувати на системні ризики такими способами:

- попередження про ризики. Повідомлення учасників фінансового ринку, інших регуляторів, органи влади, громадськість про ризики для фінансової стабільності. Це обов'язковий етап. Макропруденційне реагування вичерпується лише ним, якщо застосування макропруденційних обмежень передчасне, недоцільне або неможливе.

- запровадження макропруденційних інструментів. Якщо попередження про ризики замало, НБУ використовуватиме макропруденційні інструменти, проаналізувавши переваги та недоліки їх застосування перед 
запровадженням. Рішення про запровадження макропруденційних інструментів та їхні параметри рекомендує КФС і затверджує Правління НБУ. Якщо ризики не можуть бути усунуті заходами НБУ, він ініціюватиме їх розгляд на РФС або ініціюватиме залучення інших відомств. НБУ заздалегідь повідомляє учасників фінансового сектору про запровадження більшості макропруденційних інструментів.

IV етап. Оцінювання впливу макропруденційної політики. НБУ збирає інформацію про результати застосування макропруденційних інструментів та оцінює їі, щоб чітко розуміти всі ефекти. Після запровадження інструменту НБУ вивчить його вплив на фрінансову систему на основі аналізу звітності окремих банків, основних параметрів банківської системи та ринків, динаміки настроїв учасників фінансового ринку. Це дасть змогу визначити, чи правильно був ідентифікований ризик, чи вдалося досягти проміжних цілей, та оцінити дієвість макропруденційного інструменту. Оцінки окремих інструментів формуватимуть інтегральну оцінку макропруденційної політики. НБУ також ех ante та ex post досліджуватиме трансмісійний механізм інструментів, щоб краще зрозуміти їх функціонування та точніше їх калібрувати. Для оцінювання еорективності застосованих інструментів НБУ використовуватиме моделювання та відгуки учасників ринку [3].

У сприянні фрінансової стабільності НБУ орієнтується на рекомендації ESRB, Базельського комітету з банківського нагляду (BCBS), норм CRR/CRD IV, які, серед іншого, упроваджують макропруденційні інструменти, до яких належать:

Інструменти капіталу:

- контрциклічний буфер капіталу (countercyclical capital buffer, CCB). Активується у період кредитної експансії, знижується або деактивується в періоди економічного спаду. Знижує проциклічність фінансової системи. Залежно від фази економічного циклу може коливатися від 0\% до 2,5\% [2].

- буфер системної важливості (buffer for systemically important banks). Посилює стійкість системно-важливих установ. Установлюється залежно від категорії системної важливості банку від 1\% до 2\% [2].

- буфер системного ризику (systemic risk buffer, SRB). Зниження вразливості до довготермінових структурних (нециклічних) системних ризиків. Цей буфер на сьогодні не передбачений нормами НБУ.

- буфер консервації капіталу (capital conservation buffer, CCВ). Формується в нестресовий період для покриття збитків та недопущення порушення мінімальних вимог до достатності капіталу в майбутньому. Активація передбачена у 2020 році, буфер становитиме 0,625\% 3 поетапним збільшенням до 2,5\% до початку 2023 року [2].

- коефіцієнт левериджу (leverage ratio). Мінімальне відношення капіталу першого рівня до всіх активів (балансових та позабалансових), незважених на ризик. Планується запровадження у майбутньому, мінімальний рівень не визначено.

- додаткові ваги ризику для окремих типів кредитів. Збільшення обсягу капіталу на покриття можливих збитків за окремими типами кредитів. Потенційно може застосовуватися до валютних кредитів у майбутньому.

І. Інструменти ліквідності: 
- коефіцієнт покриття ліквідністю (liquidity coverage ratio, LCR). Визначає, скільки високоякісних ліквідних активів має утримувати банк, щоб покрити чисті відтоки коштів протягом 30 днів у кризовий період. Запроваджено у грудні 2018 року.

- коефріцієнт чистого стабільного фінансування (net stable funding ratio, NSFR). Визначає мінімальну частку стабільного (довгострокового) фондування залежно від ліквідності та залишкової строковості активів. Спонукає банки переорієнтовуватися на довгострокові джерела фінансування. Запровадження планується у 2020 році.

II. Інші інструменти:

- встановлення граничного співвідношення розміру кредиту та вартості забезпечення (loan-to-value ratio, LTV). Обмежує максимальний розмір кредиту домогосподарствам залежно від вартості забезпечення. Найчастіше застосовується до іпотечних кредитів, запобігає виникненню бульбашок на ринку нерухомості. Використання як жорсткого обмеження у найближчі роки малоймовірно, проте можливе оприлюднення рекомендацій банкам.

- встановлення граничного співвідношення суми обслуговування боргу та доходу позичальника (debt-service-to-income ratio, DSTI) або загальної суми кредиту та доходу (debt-to-income ratio, DTI). Обмежують максимальну суму кредиту, який може отримати домогосподарство, залежно від рівня його доходів. Запобігають надмірному зростанню кредитування та заборгованості домогосподарств. Використання як жорсткого обмеження у найближчі роки малоймовірно, проте можливе оприлюднення рекомендацій банкам.

- підвищені вимоги до розкриття інформації. Інструмент збільшує поінформованість громадськості про діяльність фрінансових установ, підвищуючи стійкість фрінансової системи.

Висновки. Макропруденційна політика не здатна повністю усунути системні ризики, але може не допустити їх надмірного накопичення та знизити ймовірність їх реалізації. Таким чином, вона підвищує стійкість економіки, знижує волатильність ВВП, що підтверджують результати емпіричних досліджень. Однак ця політика може мати й негативні побічні ефректи, наприклад, тимчасове погіршення доступу населення та бізнесу до кредитних ресурсів. Це може зумовлювати порівняно нижчі темпи економічного зростання - плату за стійкість до фінансових криз.

\section{Список використаних джерел:}

1. Про Національний банк України (Закон України). № 29. (1999). Вилучено 3 https://zakon.rada.gov.ua/cgi-bin/laws/main.cgi?nreg=679-14

2. Стратегія макропруденційної політики НБУ. (2019). Вилучено 3 https://events.bank.gov.ua/nbuexpress/src/files/Макропруденційна\%20політика.pdf

3. Стратегія макропруденційної політики. (2018). Вилучено 3 https://www.bank.gov.ua/admin_uploads/article/Strategy_MaP.pdf?v=4 


\section{МЕТОДОЛОГІЧНІ ЗАСАДИ ПРОЦЕСУ ФОРМУВАННЯ СТРАТЕГІЇ РОЗВИТКУ ПІДПРИЄМСТВА}

Соколова Людмила Василівна

доктор, професор кафедри економічної кібернетики

та управління економічною безпекою

Харківський національний університет радіоелектроніки

Стойка Оксана Василівна

здобувач вищої освіти фракультету

Інформаційно-аналітичних технологій та менеджменту

Харківський національний університет радіоелектроніки

УКРӒ̈НA

На сучасному етапі розвитку економіки суб'єктам господарювання доводиться фуункціонувати за умов мінливого, невизначеного та складного бізнес-середовища, так званого VUCA-світу. Високий рівень конкуренції, глобалізаційні та інтеграційні процеси, швидка зміна технологій, структури та обсягу попиту на продукцію вимагають від підприємств миттєвої реакції на виклики зовнішнього середовища, які, нажаль, усе частіше мають дестабілізуючий, кризоутворюючий характер, 3 метою утримання конкурентних позицій та, відповідно, забезпечення їх життєздатності. Це зумовлює важливість впровадження на підприємстві концепції стратегічного управління та організації ефективної системи стратегічного менеджменту.

Зміст стратегічного управління розвитком підприємства полягає в створенні необхідних умов для кількісно-якісних перетворень та координації дій, спрямованих на попередження фрормування й усунення протиріч, які виникають як у внутрішньому середовищі підприємства, так і внаслідок його взаємодії з зовнішнім середовищем. Стратегічний розвиток підприємства - це складне багатопланове та багатоаспектне явище. При побудові механізмів стратегічного розвитку може бути використаний весь арсенал економічної науки, теорії стратегічного управління та теорії розвитку [1].

Основу концепції стратегічного управління складає стратегічне позиціонування підприємства, відображене в системі принципів і цілей його функціонування, механізмі взаємодії та взаємозв'язку між елементами господарської та організаційної структури і фрормах їх пристосування до мінливих умов зовнішнього середовища. При формуванні стратегії в межах стратегічного управління підприємством необхідно враховувати не лише екстраполяцію сформованих раніше тенденцій розвитку, а й враховувати можливості і небезпеки подальшого розвитку підприємства, виникнення надзвичайних ситуацій, здатних змінити сформовані тенденції в майбутньому періоді [2].

Ключовою категорією стратегічного управління розвитком підприємства $€$ «стратегія». На нашу думку, влучним $є$ її означення як способу поведінки або 
плану, який інтегрує основні цілі організації, норми та дії в єдине ціле, допомагає направляти та розміщувати ресурси унікальним і неповторним чином, що ґрунтується на відносних внутрішніх перевагах, ключових компетенція підприємства та недоліках, очікуваних змінах в оточенні та пов'язаних з ними діями конкурентів [3].

У роботі [4] основними завданнями стратегії розвитку підприємства визначено наступні:

-концентрація економічних ресурсів у сферах, які забезпечують довгострокову ефективність діяльності підприємства;

- створення та управління високопродуктивним портфелем товарних одиниць підприємства;

- проникнення на нові сегменти ринку та укріплення конкурентоспроможності, розширення цільової аудиторії ринку в майбутньому;

- підвищення ефрективності, направленість на стабілізацію діяльності підприємства, зростання його вартості тощо.

Відповідно до рекомендацій [5] реалізація стратегії розвитку підприємства дозволяє:

- удосконалити виробничо-господарську діяльність та структуру підрозділів суб'єкта господарювання;

- підвищити ефрективність використання усіх видів ресурсів: інформаційних, фрінансових, трудових, матеріальних, нематеріальних, природних;

- створити організаційну структуру та ідеологію виробничої діяльності, які якнайповніше відповідають стратегічним цілям підприємства та забезпечують стратегічну ефеектиність у мінливому конкурентному середовищі;

- сформулювати та впровадити у щоденну практику новий образ господарчої структури як серед ії працівників, так і у зовнішньому середовищі.

Із врахуванням вищезазначеного можна зробити висновок про важливість розробки ефективної стратегії розвитку підприємства для забезпечення стійкості його функціонування, збільшення ринкової вартості та інвестиційної привабливості. Тому, доцільним є удосконалення теоретико-методологічного забезпечення процесу стратегічного управління діяльністю організації.

На основі аналізу робіт [1, 5-8], а також узагальнення сучасних підходів до стратегічного управління, було розроблено структурно-логічну схему загального процесу формування стратегії розвитку підприємства (рис. 1).

Процес розробки стратегій розвитку є багатокомпонентним та складається з наступних етапів: цілепокладання та пріоритизації; стратегічного аналізу та діагностики; впровадження та реалізації розроблених стратегій; контролю за виконанням та здійснення регулятивних заходів. Його можна охарактеризувати як безперервний та постійно-циклічний. Це зумовлено складністю та мінливістю умов зовнішнього середовища. Адже будь-яка зміна в оточенні діяльності підприємства може містити в собі як сприятливі можливості, перспективи розвитку, так і загрози фрункціонуванню. Їх потрібно враховувати та постійно коригувати стратегію, здійснювати ії актуалізацію. 

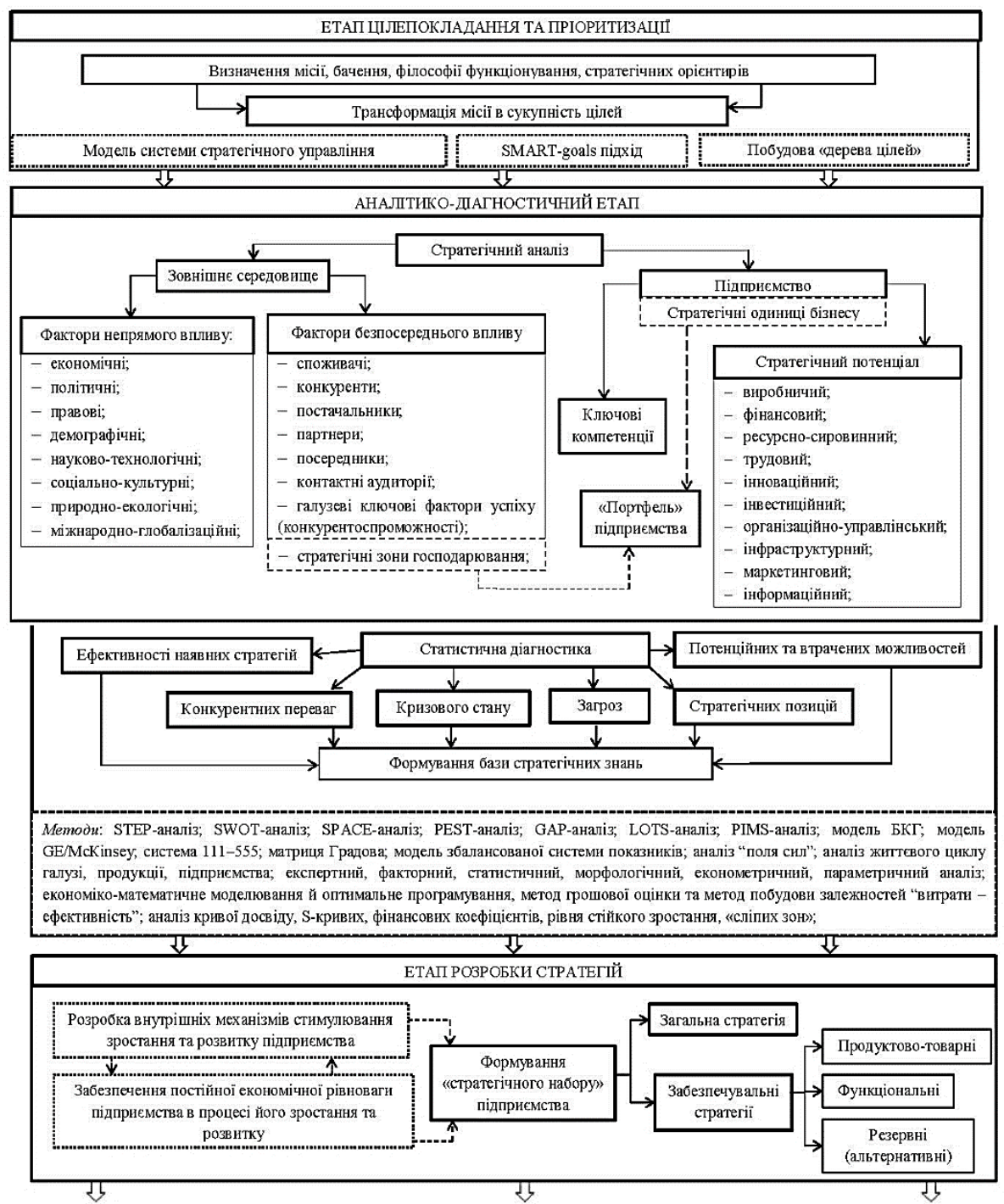

Рис 1. Структурно-логічна схема процесу формування стратегії розвитку підприємства (початок) 
Problèmes et perspectives d'introduction de la recherche scientifique innovante $\bullet$ Volume 1

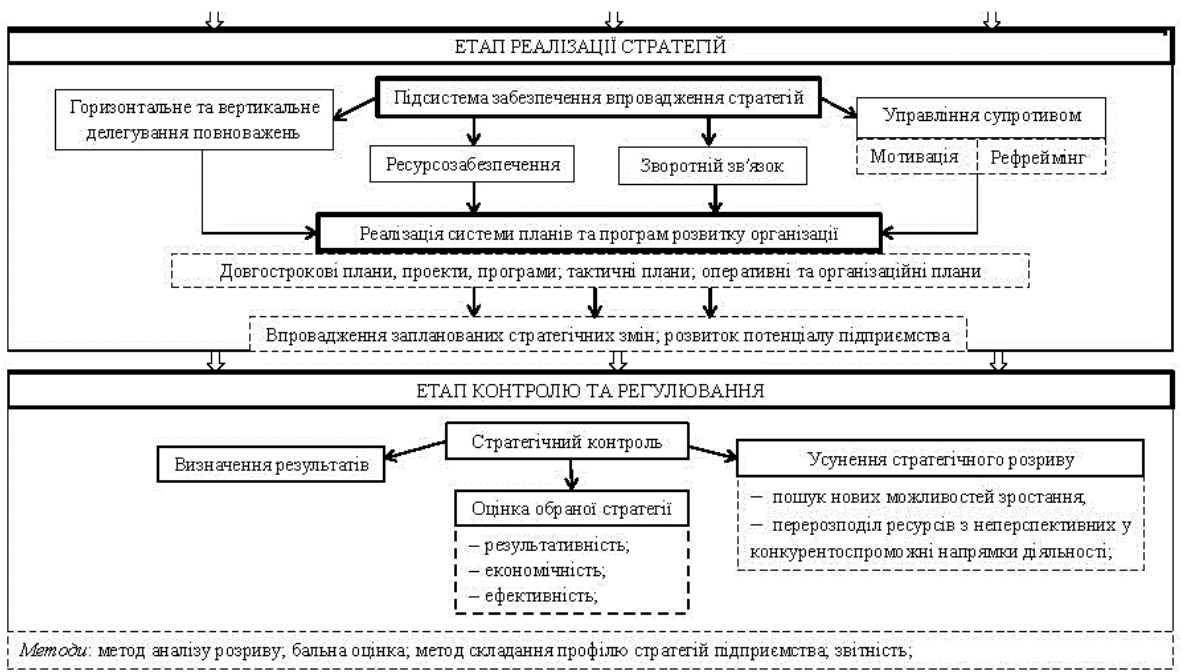

Рис 1. Структурно-логічна схема процесу формування стратегії розвитку підприємства (завершення)

Джерело: складено за [1, 5-8]

Виокремлена послідовність етапів, яку зображено на рис. 1, є більш умовною, здійсненою з метою забезпечення наочності. На практиці ж, досить часто деякі з кроків стратегічного управління здійснюються паралельно. Може також виникати потреба у поверненні до уже пройдених етапів з метою їх доопрацювання, внесення коректив.

Слід зазначити, що при формуванні стратегій розвитку підприємства важливим $€$ дотримання наступних принципів $[9,10]:$

- цілеспрямованості;

- комплексності;

- системності;

- реальності та досяжності;

- логічності;

- адаптивності та динамізму;

- принципу ітерації та беззупинності;

- ефективності;

- альтернативності;

- соціальної відповідальності.

Отже, процес розробки стратегії підприємства $є$ надзвичайно складним та багатокомпонентим процесом, що охоплює усі підсистеми підприємства, вимагає врахування цілої низки факторів та дотримання ключових принципів стратегічного управління. Однак, лише за умови його раціональної організації, правильності та сваєчасності проведеня можливе забезпечення адаптивності та стійкості у довгостроковій перспективі. Хоча стратегії й розробляються на основі неповної та неточної інформації, базуючись на припущеннях, вони $€$ надзвичайно важливими у діяльності кожного підприємства, адже дозволяють 
сконцентруватися на проблемних аспектах та визначити загальний напрямок дій, що, в кінцевому підсумку, призводить до досягнення встановлених цілей.

\section{Список використаних джерел:}

1. Пащенко, О. П. (2011). Стратегічне управління розвитком підприємства. Вісник Хмельницького національного університету. Серія Економічні науки, (2), 99-103.

2. Розумович, Н. Ф. (2016). Розробка фрінансової стратеаії у забезпеченні конкурентних переваг підприємства (дис. ... канд. економ. наук). Хмельницький національний університет. Хмельницький, Україна.

3. Куинн, Д. Б. \& Минцберг Г. (2002). Стратегии организации: понятия, формирование, примеры. Современное управление: Специальный ежемесячник современных концепций и методов менеджмента, (6), 23-69.

4. Питере, Т. В. \& Уотерман, Р. (2013). В поисках эфффективного управления: опыт лучших компаний (Л. И. Ивенко, пер. с англ.). Москва: Прогресс.

5. Касьянова, Н. В., Вецепура, Н. В., Солоха, Д. В., Сотнікова К. В., Єлетенко, О. В. (2010). Моделювання системи розвитку машинобудівного підприємства. Донецьк: ДонУЕП.

6. Муляр, Т. С. (2013). Формування і реалізація стратегії підприємств. Вісник Таврійського державного агротехнологічного університету, (2), 289-300.

7. Шершньова, 3. Є. (2004). Стратегічне управління. Київ: КНЕУ.

8. Стрільчук, Р. М. (2016) Управління стратегічними можливостями машинобудівних підприємств (дис. ... канд. екон. наук). Луцький національний технічний університет. Луцьк, Україна.

9. Хринюк, А. С. \& Усатенко, И. С. Принципи формування стратегії розвитку підприємства. Сучасні проблеми економіки та підприємництво, (8), 125-129.

10. Баланович, А. М. (2014). Теоретико-методичні засади формування стратегій розвитку підприємства. Науковий вісник Херсонського державного університету, (8), 77-81.

DOI 10.36074/29.11.2019.v1.05

МІЖНАРОДНИЙ ДОСВІД КЛАСТЕРИЗАЦІЇ ЕКОНОМІКИ

Ключенко Аделіна Вікторівна

канд. екон. наук, доцент кафедри міжнародної економіки, маркетингу і менеджменту Івано-Франківський навчально-науковий інститут менеджменту Тернопільського національного економічного університету УКРАЇНА

В сучасних економічних умовах для України вагомим залишається питання формування ефективної економічної системи. Як показує міжнародна практика, однією з ефективних форм взаємодії $€$ кластерні об'єднання організацій. Розвиток кластерів і реалізація кластерних ініціатив $€$ невід'ємною частиною модернізації економіки на сучасному етапі. У багатьох зарубіжних країнах накопичений цінний досвід і $€$ успішна практика реалізації кластерних ініціатив. 
Світова практика свідчить про активізацію процесів формування кластерних об'єднань організацій в останні два десятиліття. В даний час приблизно 50\% економік розвинених країн охоплено процесами створення і функціонування кластерних структур. Наприклад, в США діють 380 кластерів, в Італії їх налічується 206 одиниць, 168 кластерних утворень $є$ в Великобританії, в Індії діє 106 кластерів, у Франції функціонує 96 кластерних структур, в Німеччині - 32 кластера. В цілому, в Європі за останнє десятиліття сформувалося близько 2000 кластерів.

У США в рамках кластерів працює понад 50\% підприємств, а частка ВВП, виробленого в них, перевищує 60\%. У Європі в кластерних об'єднаннях організацій зайнято $38 \%$ робочої сили.

Повністю охоплені кластеризацією датська, фінська, норвезька і шведська промисловість. На промислові кластери Італії припадає 43\% чисельності працівників, зайнятих в галузі, і більше $30 \%$ обсягу національного експорту. Процес формування кластерних структур активно здійснюється в Китаї, Сінгапурі, Японії. В даний час в Китаї функціонує більше 60 особливих зонкластерів, в яких знаходиться близько 30000 фірм, в них зайнято 3,5 млн осіб, а рівень продажів досягає приблизно 200 млрд дол. на рік. Нарощування конкурентних переваг і розширення інноваційної діяльності за допомогою формування і реалізації кластерних ініціатив стає основним елементом стратегій розвитку більшості країн [1].

Процеси кластеризації, що відбуваються в національній економіці, сприяють підвищенню її конкурентоспроможності. Широке поширення для її оцінки отримав субіндекс «Рівня кластерного розвитку» Індексу глобальної конкурентоспроможності, запропонований професором Колумбійського університету К. Салай-Мартіном. На базі досліджень Світового-економічного форуму в таблиці 1 представлено ранжування країн за рівнем кластерного розвитку.

Таблиця 1

Рейтинг окремих країн згідно субіндексу «Рівня кластерного розвитку» Індексу глобальної конкурентоспроможності

\begin{tabular}{|l|c|c|c|c|}
\hline \multicolumn{1}{|c|}{ Назва країни } & $\mathbf{2 0 1 1 - 2 0 1 2}$ & $\begin{array}{c}\text { Позиція у } \\
\text { загальном } \\
\text { у рейтингу }\end{array}$ & $\mathbf{2 0 1 7 - 2 0 1 8}$ & $\begin{array}{c}\text { Позиція у } \\
\text { загальном } \\
\text { у рейтингу }\end{array}$ \\
\hline Тайвань, Китай & 5,5 & 1 & 5,3 & 4 \\
\hline Італія & 5,3 & 2 & 5,4 & 5 \\
\hline Сінгапур & 5,2 & 3 & 5,2 & 12 \\
\hline Об'єднані Арабські Емірати & 5,2 & 4 & 5,4 & 2 \\
\hline Японія & 5,2 & 5 & 5,2 & 8 \\
\hline Фінляндія & 5,2 & 6 & 4,9 & 18 \\
\hline Швеція & 5,1 & 7 & 5,0 & 16 \\
\hline Катар & 5,1 & 7 & 5,2 & 10 \\
\hline Німеччина & 5,1 & 8 & 5,4 & 4 \\
\hline США & 5,1 & 9 & 5,6 & 1 \\
\hline Швейцарія & 5,1 & 9 & 5,1 & 14 \\
\hline Великобританія & 5,1 & 10 & 5,3 & 6 \\
\hline Канада & 4,8 & 15 & 4,7 & 20 \\
\hline Данія & 4,8 & 16 & 4,6 & 22 \\
\hline Китай & 4,7 & 17 & 4,6 & 21 \\
\hline Норвегія & 4,7 & 19 & 5,2 & 9 \\
\hline
\end{tabular}


Продовження табл. 1

\begin{tabular}{|l|c|c|c|c|}
\hline \multicolumn{1}{|c|}{ Назва країни } & $\mathbf{2 0 1 1 - 2 0 1 2}$ & $\begin{array}{c}\text { Позиція у } \\
\text { загальном } \\
\text { у рейтингу }\end{array}$ & $\mathbf{2 0 1 7 - 2 0 1 8}$ & $\begin{array}{c}\text { Позиція у } \\
\text { загальном } \\
\text { у рейтингу }\end{array}$ \\
\hline Нідерланди & 4,7 & 20 & 5,3 & 7 \\
\hline Франція & 4,2 & 32 & 4,6 & 26 \\
\hline Ісландія & 3,7 & 55 & 4,1 & 42 \\
\hline Словаччина & 3,6 & 62 & 3,9 & 51 \\
\hline Польща & 3,0 & 106 & 3,7 & 71 \\
\hline Румунія & 2,8 & 116 & 3,2 & 104 \\
\hline Україна & 2,7 & 119 & 3,0 & 125 \\
\hline
\end{tabular}

Складено автором на основі [2, 3].

Індекс кластерного розвитку є найвищим для США і ОАЕ, які в даному рейтингу, станом на 2018 рік займають лідируючі позиції. Для Польщі, Румунії, Ісландії, Нідерландів виявлена найбільш позитивна динаміка зростання індексу кластерного розвитку. Для Фінляндії, Швеції, а також для України відзначається істотне зниження глобального індексу конкурентоспроможності в частині кластерного розвитку.

В зарубіжних країнах широкого поширення набули такі спеціалізації кластерів як IКT, харчова промисловість, автомобілебудування, медичні послуги, виробництво електроенергії, текстильна промисловість. Досить рідкісними є кластери таких спеціалізацій, як телекомунікації, розваги, меблі, видавництва та $3 \mathrm{Ml}$. В даний час, в межах інноваційної орієнтованості кластерних структур, спостерігається фрормування кластерів нового покоління, що спеціалізуються на інформатиці, дизайні, екології, логістиці тощо.

Досвід зарубіжних країн, що займають лідируючі позиції в питаннях кластеризації економіки, демонструє, що значна частина припадає на частку малих та середніх підприємств, наприклад, у Фінляндії - 80 \%, Австрії - 68 \%, Німеччині - $53 \%$ [4].

За кордоном більшість кластерних ініціатив реалізуються кластерними менеджерами (89 \%) або їх командою (68 \%). Відповідно до досліджень шведських учених, кластерні ініціативи виникають за пропозицією регіональної влади - в 32 \% випадків, з подачі бізнесу - в 27 \% випадків, у 35 \% випадків за ініціативою обох сторін [5].

При формуванні і реалізації кластерних ініціатив досить велику роль відіграє держава. Реалізація кластерних стратегій передбачає наявність грантоутворюючих фондів (інститутів, агентств), які підтримують кластерні ініціативи: наприклад, Національне агентство планування DATAR (Франція), Iнформаційна система пошуку і класифрікації кластерів CASSIS (Люксембург), Національна рада з конкурентоспроможності (США), програма кооперації LINK (Великобританія).

В даний час формуються спеціальні інститути, здатні ефективно виконувати функції 3 розвитку, побудови мережевих структур та їх інтернаціоналізації. До них відносяться центри експертизи (Фінляндія), центри переваги (США), консалтингові, маркетингово-аналітичні і брендингові компанії (США), Центр маркетингово-аналітичних досліджень (Казахстан); інститути і агентства, що входять в кластерні ініціативи (Мюнхенський технічний університет) [6]. 
70 • Problèmes et perspectives d'introduction de la recherche scientifique innovante $\bullet$ Volume 1

Серед країн Європи є приклади найбільш успішної реалізації кластерних ініціатив: Австрія (Верхня Австрія), Великобританія (Шотландія), Іспанія (Каталонія), Німеччина (Північна Рейн-Вестфралія), Словенія.

У Німеччині з 2003 р. уряд підтримує кластерні ініціативи, в першу чергу у сфері високих технологій, консолідацію промисловості і наукових центрів за рахунок як місцевих, так і федеральних джерел через програми підтримки регіонів і областей технологій.

Значна підтримка кластерів спостерігається в США, де високо розвинені «інститути співробітництва» (institutions for collaboration), які складаються 3 представників місцевої адміністрації, університетів, промислових груп і дослідних інститутів. Особлива роль належить університетам, їх відносинам 3 бізнесовими структурами, включаючи процедури передачі технологій університетами промисловому сектору, які чітко прописані в законодавстві США [7].

Формування і розвиток кластерних утворень особливої інтенсифікації набули в Канаді, де серед найбільш розвинених і відомих кластерних структур слід відзначити біотехнологічний, інформаційно-телекомунікаційна, мультимедійний, виноробний кластери, а також кластери високих технологій і харчової промисловості. Сприяння кластерним ініціативам бізнесу в Канаді надають всі рівні влади - федеральний, регіональний і муніципальний, але конкретні фрорми підтримки розрізняються на кожному рівні. Таким чином, проблеми формування та реалізації кластерів $є$ актуальними як для країн, в яких кластери набули широкого поширення, так і для держав, що характеризуються становленням процесів кластеризації.

На основі досліджень, важливо виділити такі критерії класифікації кластерів, як: за видами фрінансування, напрямками і цілями. За першою ознакою слід відзначити наявність трьох варіантів фінансування кластерних ініціатив: за рахунок коштів держави, приватних інвесторів або кластерні ініціативи, які мають змішане фінансування.

Питання фрінансування кластерів мають важливе значення. В багатьох країнах існує проблема недостатності фінансових ресурсів. На стадії становлення кластера повинна переважати фінансова підтримка з боку держави, в наступних стадіях життєвого циклу обсяг державного фінансування знижується. Важливим завданням для розвинених кластерів $є$ перехід на самофрінансування при мінімальній участі держави.

Цілі кластерів різноманітні, на основі існуючого досвіду можна визначити чотири: за напрямами, що відповідають за розвиток інновацій, освіти, стимулювання інвестиційної діяльності та орієнтовані на інформаційнокомунікаційний розвиток кластера.

Згідно зарубіжного досвіду, процес розвитку кластерів включає наступні етапи: ініціювання, розроблення стратегії та плану дій з розвитку кластера, формування асоціації учасників кластера, реалізацію програми розвитку, моніторинг і оцінку ефективності.

Аналіз кластерів на глобальному рівні дозволяє зробити висновок про необхідність визначення їх ефрективності. В даний час універсальної оцінки результативності кластерів поки не склалося. За підсумками розвитку кластерів збираються певні відомості і фрормується статистична інформація. 
Але з великої кількості кластерів лише 62 \% проходять офріційну процедуру оцінки [8].

На думку представників Національної науково-дослідної ради Канади, ефективні кластерні ініціативи сприяють підтримці зростання нових кластерних об'єднань організацій, серед їх основних цілей відзначаються підтримка місцевої влади і формування довгострокової стратегії на основі актуальної інформації; організація конкурентоспроможних наукових досліджень та створення регіональної технологічної бази розвитку кластерів; залучення в кластерні структури нових джерел інвестицій; стимулювання створення робочих місць, збільшення експорту, формування нових фрірм i отримання інвестицій [5].

Таким чином, успішні кластери виникають і реалізуються у сприятливому інституційному середовищі, при розвинутій конкуренції і віддаленній від командного стилю економічній політиці.

На фрормування і розвиток кластерів впливає ряд факторів стимулюючого і стримуючого характеру. Оксфордська дослідницька група визначила три групи фракторів успіху кластерів: критичні, додаткові та супутні. Серед критичних фракторів успіху виділяють міжорганізаційні мережі і партнерства на основі інноваційної бази. До додаткових фракторів успіху відносять інфрраструктуру, наявність великих бізнес-суб'єктів підприємницької культури, доступ до джерел фрінансування. Супутніми фракторами успіху кластерів $є$ доступ до ринків збуту, розвинуті комунікації, інформаційне забезпечення, ринкові умови (лідерство, конкуренція, зовнішні економічні впливи) [7].

На базі світового досвіду можна визначити чинники, що позитивно та негативно впливають на розвиток кластерів. Сприяють розвитку кластерів такі фрактори: концентрація бізнес-суб'єктів на території регіону; наявність трудових ресурсів відповідної кваліфікації, а також бази для їх розвитку; якість системи освіти; традиції виробничої кооперації і територіально-господарського планування. Серед стримуючих факторів належать: низький рівень розвитку бізнес-середовища; неефективність системи взаємодії господарюючих суб'єктів; слабкі зв'язки між освітніми та науковими установами; недостатня участь державних структур у питаннях формування кластерних об'єднань організацій та малий досвід у веденні конкурентної боротьби.

До основних положень, що сприяє підвищенню якості, обґрунтування і послідовності процесу реалізації кластерів, слід віднести:

1) підготовку кваліфрікованих кадрів для розробки і реалізації кластерних проектів;

2) формування кластерної політики, орієнтованої на специфріку конкретних кластерних структур, вибір відповідних інструментів державної підтримки;

3) удосконалення управління процесами кластеризації, що передбачає:

- включення в цільові програми реалізації кластерних проектів прогнозноаналітичних та організаційно-економічних блоків, а також забезпечення варіативності заходів в силу нестабільності зовнішнього середовища;

- формування регіонального органу, який керує процесами кластеризації;

- розробка системи проблемно-орієнтованого моніторингу.

М. Портером, основоположником кластерної теорії, представлені наступні ключові характеристики успішних кластерних ініціатив: зацікавленість 
учасників та їх широке залучення до питання розвитку та підвищення конкурентоспроможності кластера, концентрація зусиль, розвиток комунікацій між інтегрованими суб'єктами і їх мотивування на досягнення намічених результатів. Також важливим моментом успішної реалізації кластерів $€$ залучення представників владних структур.

Агентством міжнародного розвитку США встановлено, що успішна реалізація кластерів ґрунтується на сильній конкуренції на місцевому та міжнародному рівнях. Також американськими дослідниками зроблено висновок про те, що непряма підтримка кластерів може мати більший ефект, ніж пряма. Непряма підтримка може включати реформування питань кластерного регулювання, задоволення потреби в трудових ресурсах за допомогою удосконалення програм кластерів з підготовки кадрів тощо.

Таким чином, можна стверджувати, що кластери $€$ істотним елементом сучасного економічного розвитку. Вони відіграють важливе значення в питаннях модернізації економіки та підвищення її конкурентоспроможності. Формування і розвиток кластерів в Україні має ряд бар'єрів, у зв'язку з чим цінним $€$ розгляд зарубіжного досвіду. Успішний розвиток національних кластерів здатен сприяти економічному зростанню територій, розвитку взаємодії між суб'єктами кластера, представниками влади і наукою, а також позитивно вплинути інноваційну діяльність країни.

\section{Список використаних джерел:}

1. Адаманова, 3. О. (2012). Інноваційні кластери в національних економічних системах (HЕС): світовий досвід і можливості його адаптації в умовах України. Формування ринкових відносин в Україні, (5/1), 162-163.

2. Global Competitiveness Report 2011-2012. World Economic Forum. Вилучено з http://reports.weforum.org/global-competitiveness-2011-2012/ .

3. Global Competitiveness Report 2017-2018. World Economic Forum. Вилучено з http://www3.weforum.org/docs/GCR20172018/05FullReport/TheGlobalCompetitivenessReport2017\%E2\%80\%932018.pdf .

4. Комар, Н. (2014). Концепція формування та державної підтримки кластерних структур в Європі. Вісник Тернопільського національного технічного економічного університету, (2), $53-64$.

5. Левченко, А. О. \& Царенко, І. О. (2017). Зарубіжний досвід функціонування кластерних утворень та шляхи його використання в Україні. Наукові праці Кіровоградського національного технічного університету. Економічні науки, (31), 71-79.

6. Пітерська, В. М. (2018). Методологічні основи кластерного підходу в інноваційних проектах. Вісник Національного технічного університету "ХПІ". Серія: Стратегічне управління, управління портфелями, програмами та проектами, 2(1278), 38-44.

7. Попова, М. Л. (2016). Кластеры в США: роль и место малого бизнеса. Вестник Карагандинского государственного университета, (4).

8. Глобальний інноваційний індекс 2017 року. Сайт Всесвітньої організації інтелектуальної власності (WIPO).

Вилучено

3

https://www.wipo.int/pressroom/ru/articles/2017/article_0006.html. 


\title{
МІСЦЕ РЕСТОРАННОГО ГОСПОДАРСТВА В ІНДУСТРІЇ ГОСТИННОСТІ
}

\author{
Кушнір Олена Олегівна \\ Вінницький торговельно-економічний інститут КНТЕУ \\ Науковий керівник: Малюта К. Г. \\ Вінницький торговельно-економічний інститут КНТЕУ \\ УКРӒ̈HA
}

В умовах сучасності, одним із важливих складових індустрії гостинності $\epsilon$ ресторанний бізнес.

Сьогодні сучасне ресторанне господарство - це одна із перших та важливих галузей економіки, що має на меті задоволення власних потреб людини в послугах організації харчування та дозвілля, також багатообіцяючий для інвестування вид підприємницької діяльності, що дає змогу швидкого гарантування оборотності і прибутковості вкладених коштів у те чи інше підприємство.

В Україні ресторанний бізнес знаходиться на певному рівні становлення, що певним чином підвищує інтерес вітчизняних і зарубіжних підприємців та вимагає наявність інформації для визначення перспективних сегментів i зменшення ризикованості підприємницької діяльності.

Ця діяльності $\epsilon$ одним із розповсюджених видів малого бізнесу, тому більшість закладів та підприємств ведуть між собою постійну боротьбу за сегментацію ринку, а також за пошук нових та за утримання постійних споживачів їхньої продукції та послуг.

Під час організації ресторанного бізнесу, як однієї з головних сфер гостинності, необхідно керуватися принципами культури сервісу [1]:

- гість - найважливіша фігура ресторанного бізнесу, не він залежить від закладу ресторанного господарства, а заклад залежить від нього;

- гість - не перешкода, а сенс та мета роботи закладу ресторанного господарства, саме він робить послугу закладу, дозволяючи обслуговувати себе;

- гість - складова частина закладу ресторанного господарства; задача закладу - виповнити бажання гостя з користю для нього і вигодою для себе.

Задоволення потреб гостей, а потім збільшення прибутку є найважливішою метою в ресторанному господарстві. Особливу для роль для досягання цієї мети займає обслуговуючий персонал, який працює з гостями закладу.

До всіх працівників закладу ресторанного господарства виступає високий рівень вимог з точки зору професіоналізму, етики та естетики, культури обслуговування загалом.

У більшості випадків, діяльність закладів ресторанного господарства залежить від того, як закладу поталанить залучити і втримати споживачів. Це основне завдання залежить від таких складових:

- меню;

- кухня;

- інтер'єр; 
- рівень культури обслуговування;

- зовнішній вигляд і поведінка персоналу закладу;

- культура ресторанного сервісу загалом.

Ресторанне господарство протягом багатьох віків минуло складний шлях від місць для організації харчування подорожуючих до створення потужних мереж ресторанів.

До тенденцій розвитку підприємств ресторанної індустрії, що отримали розвиток в останні десятиліття, відносять:

- поглиблення спеціалізації ресторанних закладів;

- утворення міжнародних ресторанних ланцюгів;

- розвиток мережі малих підприємств;

- впровадження в індустрію гостинності комп'ютерних технологій.

Протягом останніх пару років на одному рівні із традиційними ресторанами все більше стали з'являтися спеціалізовані підприємстві зі скороченим набором пропонованих послуг.

Величезну популярність в усьому світі набули ресторани швидкого обслуговування, що спеціалізуються на гамбургерах і смаженій картоплі (McDonald's), піці (Pizza Hut, Domino, Little Ceasar), біфштексах (Sizzler), морепродуктах (Red Lobster), сандвічах (Subway).

Поглиблення спеціалізації підприємств гостинності взаємозалежне з такою найважливішою тенденцією, як утворення міжнародних ланцюгів, що відіграють величезну роль у розробленні й просуванні високих стандартів обслуговування.

Швидкі темпи розвитку ссрери гостинності вказують на такі напрями розвитку світового готельно-ресторанного бізнесу [6]:

- розширення підприємств ресторанного господарства (нові туристичні території залучатимуть і сфреру гостинності);

- зростання кількості цікавих (креативних) закладів розміщення та харчування;

- постійне технологічне переоснащення підприємств із врахуванням великої швидкості НТП (роботизація підприємств, активніше впровадження Smart технологій);

- укріплення ресторанного бізнесу, як активного елементу світової економіки;

- зростання конкурентної боротьби між представниками ресторанного господарства та, як наслідок, постійні зміни в їх функціонуванні тощо.

За статистичними даними Державної служби статистики України, станом на 1 листопада 2017 р. в Україні налічувалося 7466 активно діючих ресторанних господарств (без фрізичних осіб - підприємців) [3].

Падіння у деяких роках зумовлено тим, що відбувалось знецінення гривні, певні заборгованості підприємств, зниження платоспроможності працівникам закладів, підвищення цін на продукти та товари. Однак, з підвищенням розвитку економіки, підприємствам харчування вдалося пристосуватися до нових умов зовнішнього середовища та підвищити рівень обсягу показника. Ресторанне господарство з кожним роком все більше і стрімкіше розвивається, здобуваючи певних висот в індустрії. 


\section{Кількість діючих ресторанних господарств (підприємств тимчасового розміщення й організації харчування станом на 1 листопада кожного року)}

\begin{tabular}{|l|c|c|c|c|c|c|}
\hline \multirow{7}{*}{ Регіони } & \multicolumn{5}{|c|}{ Роки } & $\begin{array}{c}\text { Biдношення } \\
\mathbf{2 0 1 3} \text { p./ 2017 } \\
\text { p., \% }\end{array}$ \\
\cline { 2 - 7 } & $\mathbf{2 0 1 3}$ & $\mathbf{2 0 1 4}^{\mathbf{2}}$ & $\mathbf{2 0 1 5}^{\mathbf{2}}$ & $\mathbf{2 0 1 6 ^ { 2 }}$ & $\mathbf{2 0 1 7 ^ { 2 }}$ & \\
\hline Всього в Україні & 10441 & 8565 & 7926 & 6703 & 7466 & $-28,5$ \\
\hline Вінницька & 142 & 147 & 152 & 123 & 132 & $-7,0$ \\
\hline Волинська & 134 & 127 & 132 & 109 & 115 & $-14,2$ \\
\hline Дніпропетровська & 495 & 436 & 431 & 365 & 409 & $-17,4$ \\
\hline Донецька & 663 & 616 & 269 & 226 & 232 & $-65,0$ \\
\hline Житомирська & 118 & 112 & 110 & 92 & 91 & $-22,9$ \\
\hline Закарпатська & 261 & 253 & 248 & 189 & 199 & $-23,8$ \\
\hline Запорізька & 390 & 378 & 369 & 335 & 368 & $-5,6$ \\
\hline Івано-Франківська & 248 & 250 & 246 & 207 & 226 & $-8,9$ \\
\hline Київська & 479 & 435 & 442 & 409 & 439 & $-8,4$ \\
\hline Кіровоградська & 96 & 99 & 102 & 79 & 83 & $-13,5$ \\
\hline Луганська & 161 & 155 & 35 & 37 & 37 & $-77,0$ \\
\hline Львівська & 877 & 845 & 806 & 646 & 723 & $-17,6$ \\
\hline Миколаївська & 240 & 228 & 211 & 189 & 230 & $-4,2$ \\
\hline Одеська & 920 & 821 & 782 & 655 & 748 & $-18,7$ \\
\hline Полтавська & 201 & 200 & 194 & 162 & 175 & $-12,9$ \\
\hline Рівненська & 108 & 99 & 96 & 81 & 89 & $-17,6$ \\
\hline Сумська & 102 & 95 & 104 & 98 & 104 & $+2,0$ \\
\hline Тернопільська & 105 & 99 & 98 & 78 & 87 & $-17,1$ \\
\hline Харківська & 622 & 582 & 551 & 423 & 459 & $-26,2$ \\
\hline Херсонська & 195 & 183 & 196 & 172 & 202 & $+3,6$ \\
\hline Хмельницька & 161 & 155 & 145 & 108 & 115 & $-28,6$ \\
\hline Черкаська & 131 & 135 & 131 & 131 & 138 & $+5,3$ \\
\hline Чернівецька & 138 & 129 & 126 & 94 & 99 & $-28,3$ \\
\hline Чернігівська & 158 & 146 & 151 & 139 & 147 & $-7,0$ \\
\hline Київ & 1955 & 1840 & 1799 & 1556 & 1819 & $-6,9$ \\
\hline
\end{tabular}

Таким чином, суспільство не стоїть не місці, постійно відбуваються зміни на ринку ресторанних послуг. Це зумовлено тим, що ресторанний бізнес - це така сфера діяльності, частина індустрії гостинності, яка має повну залежність від вражень та відгуків споживачів. Потрібно постійно розвиватись та підтримувати ресторанний бізнес як частину індустрії гостинності, що являє собою обличчя країни, цей напрям вимагає подальших досліджень.

\section{Список використаних джерел:}

1. Цирульнікова, В. В. (2013). Ресторанна справа: курс лекцій. Київ.

2. The World's Largest Fast Food Restaurant Chains. Retrieved from https://www.worldatlas.com/articles/the-world-slargest-fast-food-restaurant-chains.html.

3. UNWTO. Retrieved from http://www2.unwto.org/.

4. Subway. Retrieved from http://www.subway.com/en-us.

5. Офріційний сайт МакДонадз Україна. Вилучено з https://www.mcdonalds.ua.

6. Посохов, І. (2017). Сучасний стан і структура європейського ринку готельних послуг. Парфіненко А.Ю. (ред.). Сучасні тенденції розвитку готельно-ресторанного бізнесу: 
76 • Problèmes et perspectives d'introduction de la recherche scientifique innovante $\bullet$ Volume 1

міжнародний та національний досвід: колективна монограсрія (с. 74-88). Х.: XНУ імені В.Н. Каразіна.

7. Державна служба статистики України (2017). Retrieved from www.ukrstat.gov.ua.htm.

\section{НЕЙРОМАРКЕТИГ, ЯК СКЛАДОВИЙ ЕЛЕМЕНТ МАРКЕТИНГОВИХ ДОСЛІДЖЕНЬ}

\section{Лабенська Юлія Дмитрівна}

здобувач вищої освіти економічного фракультету

Запорізький національний університет

Науковий керівник: Терентьєва Наталія Валеріївна, канд. ек. наук, старший викладач кафедри управління персоналом та маркетингу Запорізький національний університет

УКPÄ̈HA

В сучасних ринкових умовах, традиційні концепції маркетингу, котрі існували протягом багатьох років, майже вичерпали себе та зазнали значного зменшення ефективності впливу на споживачів. Саме тому велика кількість провідних компаній та брендів використовує нейромаркетинг для збереження лідерських позицій, збільшення частки ринку та підвищення обсягів продажу.

Нейромаркетинг визначають, як комплекс методів спрямованих на дослідження біологічного аспекту поведінки споживачів, що супроводжується використанням когнітивних та нейробіологічних наук для аналізу підсвідомих рішень про купівлю. Він включає в себе декілька видів комунікацій та позиціонування товару, котрі прискорюють прийняття рішення про придбання товару завдяки впливу на певні ділянки головного мозку та зорові, слухові, нюхові, кінестичні органи почуттів. Так основними технологіями нейромаркетингу $€$ візуальний мерчандайзинг, звуковий дизайн та аромамаркетинг [1].

Візуальний мерчандайзинг дозволяє збільшити об'єм продажу за допомогою правильної презентації товару. На позитивне сприйняття продукції споживачами впливають освітлення в торговому залі, зовнішній вигляд вітрин, розташування товару, кольорова гама та емоційна атмосфера. Оптимальне поєднання кольорів дає змогу відділиться серед конкурентів, викликати необхідні емоції у споживачів та створювати рекламну продукцію посиленого впливу

Ще однією складовою нейромаркетингу є звуковий дизайн. Музика впливає значно впливає на настрій покупців. Особливу роль при здійснені покупки має темп та стиль фонової музики, що визначає тривалість знаходження споживачів в магазині. Так, спокійні мелодії надають більше часу на роздуми та вибір товару, а енергійні - примушують покупців швидко приймати рішення. Гучність звуку впливає на психоемоційний стан споживачів та на кількість придбаного товару.

Мета ароматичного маркетингу - за допомогою запахів впливати на поведінку клієнтів, забезпечувати позитивне сприйняття пропозиції. Було доведено, що завдяки використанню ароматів у точках продажу число покупок 
було збільшено на 80\%. Аромамаркетинг охоплює ароматизацію повітря, аромамерчандайзинг, тобто звернення уваги споживачів на певні продукти та аромабрендинг [2].

Для дослідження підсвідомого ставлення споживача до товару або до рекламних комунікацій та стратегій маркетологи активно використовують біологічні та медичні методи. За допомогою МРТ можна отримати візуалізацію діяльності мозку під час впливу подразників та, завдяки цьому, розробити максимально ефективні рекламні звернення, котрі будуть викликати необхідні емоції. Також вимірюють ритми активності нейронів мозку внаслідок змін емоційного стану, частоту дихання, серцебиття, електричний опір шкіри та реєструють скорочення м'язів обличчя. Отримані данні дозволяють аналізувати та прогнозувати поведінку споживача, обсяг продажів та створювати продукти, які повністю задовільнять всі вимоги покупців [3].

Отже, нейромаркетинг на даному етапі розвитку підприємництва $\epsilon$ передовою технологією, котра поєднує в собі як біологічні, так і маркетингові ослідження i експерименти. Нейромаркетинг дає можливість не лише підвищити ефрективність маркетингових комунікацій, а також збільшити попиту і прибуток компанії.

\section{Список використаних джерел:}

1. Котова, П.К., Сенина, А.С. (2019) Технологии нейромаркетинга. «Научно-практический электронный журнал Аллея Науки, $(1,28)$.

2. Колесніков, А., Шульгат, Н. (2011) Нейромаркетинг: новітні інструменти ототожнення бренду. Соціально-економічні проблеми і держава, ( 2).

3. Farnsworth, B. (2019) 15 Powerful Examples of Neuromarketing in Action. Imotions. Retrieved from $3 \mathrm{https}: / /$ imotions.com/blog/neuromarketing-examples/

\section{НАПРЯМИ ВДОСКОНАЛЕННЯ ОРГАНІЗАЦІЇ ФІНАНСОВОЇ ДІЯЛЬНОСТІ НА ПІДПРИЄМСТВІ}

НАУКОВО-ДОСЛІДНА ГРУПА:

Паньків Юлія Ігорівна

студентка фракультету фрінансів та обліку Тернопільський національний економічний університет

Яцканич Ангеліна Віталіївна

студентка фракультету фрінансів та обліку

Тернопільський національний економічний університет

Гупаловська Мирослава Богданівна канд. екон. наук, доцент, доцент кафедри фрінансів ім. С. І. Юрія

Тернопільський національний економічний університет

УKPAÏHA

У сучасних економічних умовах діяльність кожного підприємства, організації є предметом уваги широкого кола учасників ринкових відносин, які зацікавлені в результатах його функціонування. Основним інструментом 
виступає економічний аналіз, який допомагає об'єктивно оцінити внутрішні і зовнішні відносини об'єкта, проаналізувати його платоспроможність, ефективність та прибутковість діяльності, перспективи розвитку, а потім за його результатами прийняти обґрунтовані рішення. [1]. Але, сьогодні існує низка нерозв'язаних проблем теоретичного та методологічного характеру, які пов'язані з виявленням принципів і чинників стійкого функціонування й розвитку суб'єктів підприємництва, зокрема управління фрінансовою діяльністю підприємств; відсутністю єдиної концепції, що комплексно пов'язує різні види й чинники фрінансового механізму забезпечення розвитку підприємств. Тому потрібно запропонувати заходи щодо покращення фрінансового стану суб'єктів підприємництва та активізації їх фінансової діяльності.

Фінансова діяльність - це діяльність, спрямована на забезпечення підприємства фінансовими ресурсами та досягнення ним визначених цілей економічного та соціального розвитку. Тому фінансова діяльність зумовлює зміни як обсягу, так і складу власного та залученого капіталів підприємства [2]. Систематичної оцінки в динаміці фінансових результатів і аналізу основних факторів, які впливають на формування чистого прибутку потребують удосконалення системи управління фрінансовою діяльністю підприємства, а також підвищення його прибутковості. Тому необхідно виокремити основні напрями вдосконалення організації фінансової діяльності на підприємстві, а саме: системний та постійний аналіз фінансової діяльності; оптимізація витрат підприємства на основі поділу їх на постійні та змінні організація оборотних коштів із метою оптимізації фінансового стану; використання лізингових відносин; оптимізація розподілу прибутку та вибір найбільш ефективної дивідендної політики; більш широке впровадження комерційного кредиту і вексельного обігу; оптимізація структури вартості майна підприємства та джерел його формування; розробка та реалізація фрінансової стратегії підприємства.

Можна зробити висновок, що фінансова діяльність займає особливе місце в організаційній та управлінській роботі підприємств. У сучасних умовах необхідно шукати найбільш ефективні напрямки вдосконалення організації фінансової діяльності, реалізація яких буде сприяти підвищенню конкурентоспроможності, прибутковості та стабільності на підприємстві.

\section{Список використаних джерел:}

1. Ладунка І.С. \& Кучеренко Є.А. (2016) Шляхи покращення фінансового стану підприємств в сучасних економічних умовах. Економіка і суспільство, (15), 185-188. Вилучено з: http://www.economyandsociety.in.ua/journal/5_ukr/33.pdf .

2. Карпова Т. С. \& Позднякова О.В. (2014) Проблеми та шляхи вдосконалення управління фінансовою діяльністю суб'єктів підприємництва в Україні. Финансы, учет, банки, (1), 144152. Вилучено 3: http://nbuv.gov.ua/UJRN/Fub_2014_1_21 .

3. Рубаха М.В. \& Галайко А.М. (2017) Вдосконалення фінансового планування як передумова ефективної діяльності підприємств у сучасних економічних умовах. Економіка та суспільство, $\quad$ (9), 614-618. http://www.economyandsociety.in.ua/journal/9_ukr/104.pdf. 


\section{«НОВАЯ ЭКОНОМИКА»: СОЦИАЛЬНО-ЭКОНОМИЧЕСКАЯ ПРИРОДА}

\section{Зайцев Александр Константинович}

студент 5-го курса

Санкт-Петербургский государственный экономический университет

РОССИЙСКАЯ ФЕДЕРАЦИЯ

Термин «Новая экономика» вводился западными экономистами, характеризует ситуацию, сложившуюся в странах «большой семерки» в 90-е годы прошлого века. Это период бурного роста и развития бизнес-компаний, связанных с разработкой и внедрением информационных технологий, компьютерной техники, программного обеспечения, интернет-проектов и т.д.

Впоследствии для обозначения изменений, происходящих в обществе последние десятилетия, в научной литературе используются два термина: «экономика знаний», или «новая экономика», и «информационная экономика». Экономисты Н.И. Базылев и Н.Л.Грибанова в статье «Новая экономика, ее движущие силы и тенденции развития» выделяют четыре подхода к определению понятия «новой экономики»:

При первом подходе к «новой экономике» относится вся предпринимательская деятельность, использующая современные электронные информационные и коммуникационные технологии. Согласно данному подходу под «новой экономикой» понимается комплекс наукоемких отраслей, занятых производством и обслуживанием информационнокоммуникационного оборудования, созданием и распространением программных продуктов, развитием коммуникационных сетей.

Второй подход включает в понятие «новой экономики» организационные и институциональные новации в деятельности различных (в том числе и традиционных) отраслей экономики ряда развитых стран. Такое определение «новой экономики» представлено в концепции Совета экономических консультантов при Президенте США. Согласно ей американская экономика последнего десятилетия $\mathrm{XX}$ века в целом характеризуется как «новая экономика» в связи с экстраординарным приростом ее показателей, что стало результатом комбинированного эффекта от взаимодействия достижений в технологии, деловой практике и экономической политике.

Третий подход концентрируется на финансовой составляющей «новой экономики» и определяет ее как одну из вершин международной финансовой экономики, финансовой модели хозяйствования, широко использующей инструментарий информационно-технологических инноваций в валютнофинансовой системе.

Четвертый подход определяет «новую экономику» как совокупность отраслей, характеризующихся более значительным удельным весом человеческого капитала по сравнению с материальными элементами. В этих 
отраслях технологическая реализация знаний играет решающую роль, а производство знаний является источником экономического роста [1].

Сегодня многие узко трактуют это понятие, которое в действительности значительно шире и относится не только к новым бизнесам в Интернете, но и к старым, отражая то, что привносит в них новая экономика.

Таким образом, «Новая экономика» - совокупность нескольких высокоэффективных подотраслей экономики, ориентированных на использование интеллектуальной составляющей общественного развития и базирующихся на передовых информационных технологиях, интернетрешениях: консалтинг, инновации, образование, интернет-трейдинг.

Одновременно с этим «Новая экономика» является движущей силой одной из ключевых тенденций развития мировой экономики, а именно прогрессирующей глобализации [2].

\section{Список используемых источников:}

1. Bazylev, N.I., Gribanova, N.L. (2006). "New economy." Its driving forces and development trends. Problemy sovremennoi ekonomiki (The Problems of Modern Economics), (1/2), 17-18.

2. Gorbachev, M.S. (2003). The facets of globalization: Difficult issues of modern development. M.: Alpina Publisher.

\section{ОБЛІК ЗАЛУЧЕНОГО КАПІТАЛУ ПІДПРИЄМСТВА}

\section{Слєсар Тетяна Миколаївна}

канд. екон. наук

Національний університет біоресурсів і природокористування України

Якубчик Олександра Олександрівна

здобувач вищої освіти

Національний університет біоресурсів і природокористування України

УКРАÏHA

Ефективна фрінансова діяльність підприємства неможлива без постійного залучення позикових коштів. Їхнє використання в обороті підприємства зумовлене, з одного боку, об'єктивною необхідністю, а саме: невідповідністю у часі між надходженнями коштів та витратами, сезонністю виробництва, впровадженням інвестиційних проектів, які потребують значних обсягів вкладень; з другого боку, за допомогою позикових коштів забезпечується розширення виробничо-господарської діяльності, оновлення технічної бази, використання ефректу фрінансового левериджу та ін.

Значний внесок в удосконалення обліку й аналізу залученого капіталу зробили вчені І.О. Бланк, М.Т. Білуха, О.Д. Василик, В.М. Івахненко, К.В. Ізмайлова, М.Я. Коробов, Л.А. Лахтіонова, Л.О. Лігоненко, А.А. Мазаракі, В.О. Мец, Є.В. Мних, В.М. Опарін, П.Я. Попович, В.В. Сопко, С.І. Шкарабан та iH. 
Залучений капітал формує зобов'язання підприємства. Згідно з МСБО 37 «Забезпечення, умовні зобов'язання та умовні активи», зобов'язання - це заборгованість підприємства, що виникла внаслідок минулих подій і погашення якої, як очікується, призведе до зменшення ресурсів підприємства, що втілюють у собі економічні вигоди [1].

Серед зобов'язань основне місце займає позиковий капітал, тобто фрінансові зобов'язання. Він включає: довгостроковий позиковий капітал довгострокові кредити банків, довгострокові позикові кошти; короткостроковий позиковий капітал - короткострокові кредити банків, короткострокові позикові кошти, кредиторська заборгованість, інші короткострокові зобов'язання.

Довгострокові кредити банків, як правило, пов'язані 3 придбанням устаткування або виконанням інвестиційних проектів. Основною рисою довгострокових кредитів $€$ великі ризики, більш складні умови обслуговування та виконання у вигляді забезпечення. Наприклад, проектні кредити (кредити під виконання інвестиційних проектів) видаються банками на основі глибокого аналізу, бізнес-планів інвестиційних проектів та під надійне забезпечення. Це найбільш ризикові кредити. Іпотечні кредити видаються під заставу нерухомості та земельних ділянок.

У балансі залучений капітал підприємства відображається у складі зобов'язань за умови, що оцінка цих зобов'язань може бути достовірно визначена та існує ймовірність зменшення економічних вигід у майбутньому внаслідок їх погашення.

Залежно від строків виконання зобов'язань вітчизняними стандартами бухгалтерського обліку залучений капітал поділяється на довгостроковий i поточний. Довгострокові зобов'язання і відповідно довгостроковий позиковий капітал підприємства можна класифікувати за такими видами: позички банків та інші позички, термін погашення яких перевищує 12 календарних місяців; довгострокові зобов'язання за емітованими облігаціями; відстрочені податкові зобов'язання; довгострокові векселі видані; довгострокові зобов'язання 3 фінансової оренди та оренди цілісних майнових комплексів; інші довгострокові зобов'язання, зокрема відповідно до законодавства відстрочена заборгованість з податків (інших обов'язкових платежів), фінансова допомога на зворотній основі. Під поточними (короткостроковими) зобов'язаннями необхідно розуміти зобов'язання, що будуть погашені протягом операційного циклу або повинні бути погашені протягом 12 місяців 3 дати складання балансу.

Основними джерелами формування залученого капіталу є:

1) грошові кошти, що тимчасово звільняються у процесі кругообігу промислового і торговельного капіталів, нагромаджені у формі амортизаційних відрахувань, частини оборотного капіталу (внаслідок незбігу часу продажу товарів і купівлі предметів праці - сировини, палива, матеріалів), тимчасово вільних коштів для виплати заробітної плати і призначеної для капіталізації додаткової вартості (внаслідок поступового нагромадження необхідної величини для купівлі нових машин, устаткування, будівництва складів тощо);

2) особисті грошові доходи і заощадження населення країни;

3) грошові нагромадження держави, зумовлені процесами одержавлення економіки і насамперед національного доходу [2]. 
До основних зовнішніх джерел формування позикового капіталу підприємств належать: банківські (фрінансові) кредити; кошти, залучені в результаті емісії облігацій; комерційні позички.

Усі витрати (проценти, комісійні тощо) підприємств, пов'язані із залученням та обслуговуванням позикового капіталу, відображаються за статтею "Фінансові витрати" Звіту про фінансові результати.

Аналіз сутності залученого капіталу дозволяє зробити наступні висновки:

1. Залежно від строків виконання зобов'язань залучений капітал поділяється на довгостроковий і поточний;

2. Фінансовим кредитом $€$ засоби, надані фінансовою установою в позику юридичній чи фізичній особі на визначений строк та під відсотки. В Україні регулювання кредитних відносин здійснюється Національним банком України, Верховною Радою України, Кабінетом міністрів України;

3. Найпоширенішою формою кредиту є банківський кредит, але, крім того, розрізняють комерційний, споживчий, іпотечний, лізинговий, консорціумний, бланковий та інші види кредиту;

4. До моменту звернення до фрінансової установи з метою отримання позики, раціональним $€$ проведення підприємством аналізу власної привабливості в якості позичальника для банку. Основними показниками, які необхідно проаналізувати $€$ коефріцієнти ліквідності (миттєвої, поточної, загальної), коефіцієнти стійкості, рентабельності (активів, продажу), аналіз грошових потоків.

\section{Список використаних джерел:}

1. М(С)БО 37 «Забезпечення, умовні зобов'язання та умовні активи». Вилучено 3 https://zakon.help/article/mizhnarodnii-standart-buhgalterskogo-obliku-37.

2. П(С)БО 11 «Зобов'язання». Вилучено з http://buhgalter911.com/Res/PSBO/ PSBO11.aspx.

\section{ОПТИМІЗАЦІЯ СТРУКТУРИ БУХГАЛТЕРСЬКОГО БАЛАНСУ ЯК ФАКТОР ПІДВИЩЕННЯ ЛІКВІДНОСТІ ТА ПЛАТОСПРОМОЖНОСТІ ПІДПРИЕМСТВА}

Гаспарян Гаспар Кароєвич

студент кафедри фінансів суб'єктів господарювання та інноваційного розвитку ДВНЗ Криворізький національний університет

Науковий керівник: Короленко С.М. кандидат економічних наук, доцент ДВНЗ Криворізький національний університет УКРАÏHA

Постановка проблеми. Ліквідність і платоспроможність підприємств $є$ об'єктивними складними та багатогранними економічними явищами. Ліквідність $€$ мірою здатності компанії, своєчасно виконувати свої зобов'язання, при настанні терміну погашення. Рівень ліквідності 
характеризується питомою вагою легко реалізованих активів, в балансі підприємства. Ліквідність легко утримувати, легко визначати, але складно визначити рівні ліквідності для кожного класу активів. Психологічна, соціальна і політична ситуація також $є$ фрактором ступеня ліквідності.

Серед них оборотні активи є найбільш ліквідними, включаючи грошові кошти та інші активи, які можуть бути реалізовані протягом одного року з дати складання бухгалтерського балансу. Збільшення трансакційних витрат підприємства може знизити ліквідність активів, наприклад збільшення державних зборів, податків, мит, що може знизити ліквідність акцій [4]. Операції РЕПО збільшують ліквідність, що дає можливість компанії мати дешевий короткостроковий позику грошових коштів під заставу цінних паперів (облігацій, векселів, депозитних сертифікатів), що належать продавцю, найчастіше короткострокових боргових паперів грошового ринку - при цьому, чисто юридично, угода РЕПО оформляється як купівля і продаж, а не як позику.

Коефіцієнти ліквідності характеризують здатність підприємства погашати короткострокові боргові зобов'язання і конвертувати свої активи в грошові кошти. Ліквідність не слід плутати з платоспроможністю. Платоспроможність вимірює здатність компанії виконувати свої фрінансові зобов'язання [7]. Компанії можуть отримувати прибуток, якщо у них $€$ проблеми 3 відшкодуванням, наприклад в період розширення. Підприємства можуть мати кращу платоспроможність в разі зменшення майбутніх доходів і дебіторської заборгованості. Але в той же час відсутність прибутку і нездатність платити зазвичай означають, що компанія знаходиться на межі банкрутства.

Аналіз останніх досліджень. 3'ясуванню сутності та удосконаленню визначення ліквідності присвятили свої праці М. Болек (Bolek M.), В. Вилинські (Wilinski W.), A. Бреуер (Breuer A.). Удосконаленню методики розрахунку й аналізу коефіцієнтів ліквідності, проблемам пошуку найбільш релевантних рекомендованих діапазонів їх значень присвятили свої праці А.П. Дорошенко, Ц. Цостеа (Costea С.), Ф. Хостиуц (Hostiuc F). Дослідженню основних характерних рис коефіцієнтів ліквідності, з'ясуванню їх ролі і значення у формуванні ділової репутації підприємства присвятили свої праці І.М. Лінтур, Х.М. Ковач, Н.М. Побережна, Н.Ю. Єршова, Ю.Ю. Івахів, С.Р. Романів, С. Атіе (Atieh S.).

Формулювання цілей дослідження. Метою статі $€$ підвищення i нормалізація ліквідності та платоспроможності підприємства за рахунок розробки теоретичних основ та побудови оптимізаційної моделі структури бухгалтерського балансу ПАТ «Арселор Міттал Кривий Ріг» і методів контролю характеристик коефіцієнтів ліквідності та платоспроможності та їх вимірювання при наявності та відсутності відхилень від нормативного значення.

Виклад основного матеріалу дослідження. Головним завданням управління фрінансовим потенціалом підприємства $€$ оптимізація фрінансових потоків з метою збільшення позитивного фінансового результату. 3 метою дослідження важливості даних балансу для оцінки фінансового стану підприємства проведено аналіз господарських засобів підприємства та джерел їх утворення ПАТ «Арселор Міттал Кривий Ріг» у 2016 - 2018 рр. (табл. 1). Для наочності структури та динаміки активів підприємства сформуємо складові балансу даного підприємства на рис. 2. Побудова гнучких виробничих систем $\epsilon$ ефективним підходом для досягнення росту продуктивності підприємства. Основна ідея їх створення передбачає автоматизацію тих операцій, де існує 
технічна потреба та економічно обґрунтована необхідність. Як наслідок, операції стають більш ефективними за системи з повною автоматизацією. Масштабність розвитку й застосування операційного менеджменту в різних підприємствах надає можливість визначити триєдиний об'єкт - це операції, процеси й операційні системи. Це обґрунтовується тим, що головний вектор дії операційного менеджменту сучасної організації спрямований не лише на операції, а й на процеси та операційні системи, де саме виконують останні. За результатами проведеного дослідження можна зробити висновок про загальне збільшення активів підприємства впродовж аналізованого періоду. 32016 по 2017 роки відбулося збільшення активів на 8095,4 млн гривень. У 2018 р. спостерігалося зростання активів на 8611,4 млн грн, або на 10,0 \% у 2017 р., та на 9,7 відсотків у 2018 р. Така позитивна тенденція свідчить про збільшення обсягів виробництва та продажів продукції, а отже і стабільності отримання доходу від реалізації продукції.

Крім того в науковій літературі для визначення ступеня ліквідності і платоспроможності використовують різні варіанти порівнянь активів і пасивів за основними активами. Умовно їх об'єднати в три групи [4]:

1) коефіцієнти прямої ліквідності балансу, що відображають ліквідність балансу з урахуванням фактору часу i розраховуються як відношення відповідних груп активів і пасивів;

2) показники ліквідності, що відображають ліквідність активів по відношенню до найбільш термінових зобов'язань (П1);

3) основні коефіцієнти ліквідності, що відображають ліквідність балансу по відношенню до найбільш термінових та короткострокових зобов'язань $(П 1+$ П2);

4) показники ліквідності, що відображають ліквідність балансу по відношенню до найбільш термінових, короткострокових та довгострокових зобов'язань $(П 1+\Pi 2+\Pi 3)$.

Таблиця 1

\section{Обсяг і структура активів та пасивів ПАТ «АрселорМіттал Кривий Ріг»} у 2016-2018 роках

\begin{tabular}{|c|c|c|c|c|c|c|c|}
\hline \multirow{2}{*}{ Показники } & \multicolumn{3}{|c|}{ Період } & \multicolumn{2}{|c|}{ Відхилення 2017/16 } & \multicolumn{2}{|c|}{$\begin{array}{c}\text { Відхилення } \\
2018 / 17\end{array}$} \\
\hline & 2016 p. & 2017 p. & 2018 p. & $+/-$ & $\%$ & $+/-$ & $\%$ \\
\hline Активи & 80967,6 & 89063,0 & 97674,4 & 8095,4 & 10,0 & 8611,4 & 9,7 \\
\hline Необоротні активи & 54022,7 & 55185,4 & 58390,9 & 1162,7 & 2,2 & 3205,5 & 5,8 \\
\hline - у \% до ВБ & 66,7 & 62,0 & 59,8 & $-4,7$ & $-7,0$ & $-2,2$ & $-3,6$ \\
\hline Оборотні активи & 26944,9 & 33877,6 & 39283,5 & 6932,7 & 25,7 & 5405,9 & 16,0 \\
\hline - у \% до ВБ & 33,3 & 38,0 & 40,2 & 4,7 & 14,1 & 2,2 & 5,8 \\
\hline Пасиви & 80967,6 & 89063,0 & 97674,4 & 8095,4 & 10,0 & 8611,4 & 9,7 \\
\hline Власний капітал & 60181,0 & 65226,8 & 74490,9 & 5045,8 & 8,4 & 9264,1 & 14,2 \\
\hline - - $\%$ до ВБ & 74,3 & 73,2 & 76,3 & $-1,1$ & $-1,5$ & 3,1 & 4,2 \\
\hline $\begin{array}{l}\text { Довгострокові } \\
\text { зобов'язання і } \\
\text { забезпечення }\end{array}$ & 6935,0 & 6791,9 & 8054,7 & $-143,1$ & $-2,1$ & 1262,8 & 18,6 \\
\hline - - $\%$ до ВБ & 8,6 & 7,6 & 8,2 & $-1,0$ & $-11,6$ & 0,6 & 8,5 \\
\hline $\begin{array}{l}\text { Поточні зобов'язання } \\
\text { i забезпечення }\end{array}$ & 13851,6 & 17044,4 & 15128,8 & 3192,8 & 23,1 & $\mid-1915,6$ & $-11,2$ \\
\hline - $\mathrm{y} \%$ до ВБ & 17,1 & 19,1 & 15,5 & 2,0 & 11,7 & $-3,6$ & $-18,9$ \\
\hline
\end{tabular}

Джерело: розраховано за даними [3] 
На нашу думку необхідно розрізняти дві задачі аналізу ліквідності балансу - це аналіз абсолютної ліквідності балансу, що полягає у порівнянні відповідних груп активів і пасивів, і аналіз відносної ліквідності балансу, що полягає у порівнянні певним чином об'єднаних груп активів і пасивів. Здійснюватися такий аналіз повинен як за абсолютними, так і відносними показниками. Таким чином, буде забезпечена якісна визначеність результаті.



\section{Рис. 2. Динаміка та структура активів ПАТ «АрселорМіттал Кривий Ріг» у 2016-2018 роках Джерело: розраховано за даними [3]}

На рисунку 2, можна спостерігати, що необоротні активи, мають значну динаміку та перевагу в порівнянні з оборотними активами за досліджуваний період. Показники активів, а саме їх ліквідності позначають рівень згідно певних нормативних значень, і тому аналіз ліквідності активів $€$ важливістю якості ліквідності активів. Для прикладу потрібно вказати, що для ліквідних активів визначають - 0,2 (20\%), швидко ліквідних - 0,3 (30\%) і повільно ліквідних - 0,5 (50\%) [8]. При даному аналізі, потрібно провести співставлення частки кожної групи нормативів з активами оборотними. Інтеграційні особливості показників допоможуть прослідкувати врахування дефріциту менш ліквідних активів за рахунок надлишку більш ліквідних, але в цьому випадку потрібно враховувати недостатню ліквідність коли відчувається брак активів високоліквідних і коли ці активи є не дохідними, і саме тоді може відбуватись суттєва втрата прибутну від підприємницької діяльності.

Спицький А.В. [6] радить використовувати в рамках наукових досліджень показник інтегрального спрямування, що дозволяє здійснювати аналіз ліквідності балансу і відповідно цей баланс має наступний виклад: $A 1 \geq \Pi 1 ; A 1+$ $\mathrm{A} 2 \geq \Pi 1+\Pi 2 ; \mathrm{A} 1+\mathrm{A} 2+\mathrm{A} 3 \geq \Pi 1+\Pi 2+\Pi 3 ; \mathrm{A} 4 \geq \Pi 4$. Згідно наукової позиції В.О.Подольської [5], яка використовує нерівності, що характеризують різний тип фрінансової стійкості абсолютний, нормальний, передкризовий (критичний), кризовий. Система ощадливого виробництва виступає інструментом, 
використання якого сприяє скороченню витрат та втрат і зможе допомогти оптимізувати структуру бухгалтерського балансу як фрактор підвищення ліквідності та платоспроможності підприємства.

Для досягнення необхідної оптимізації балансу, спираючись на показники фінансової стійкості, ми бачимо, що для його реалізації необхідно збільшити власний капітал і грошові кошти. Нами запропоновано два варіанти залучення додаткового фінансування:

1. Кредитування під заставу активів - як правило, це фінансове кредитування під заставу дебіторської заборгованості, запасів, машини і обладнання. Отже низько ліквідні активи, замінюються ліквідними, показники рентабельності прагнуть верх, при цьому збільшується сума позикового і знижується питома вага власного капіталу.

2. Фінансування під розвідані запаси сировини. Механізм цього інструменту досить простий, забезпеченням $€$ родовище 3 підтвердженими запасами природних ресурсів, а значить, і правами на їх видобуток і подальшу реалізацію. Компанія погашає заборгованість, за рахунок коштів, отриманих від продажу видобутої сировини.

Проведене дослідження дозволило з'ясувати, що бухгалтерський баланс $€$ однією з основних форм звітності, яка поступово удосконалюючись в напрямі підвищення своєї інформативності та можливості використання в управлінні підприємством. Практична значущість отриманих результатів полягає в можливості їх використання під час проведення практичної аналітичної роботи з діагностики ліквідності підприємства Саме баланс $\epsilon$ основною інформаційною базою для проведення аналізу фінансового стану підприємства, складу та структури майна та ефективності його використання, наявність власного капіталу, складу та динаміки дебіторської та кредиторської заборгованості, що зумовлює його ключове значення у загальній системі фінансової звітності підприємства. Таким чином, підтверджується гіпотеза про те, що розробка ефективної моделі оптимізації структурних елементів бухгалтерського балансу надає можливість суттєво покращити показники фінансової стійкості підприємства. Подальші дослідження можуть бути пов'язані з уточненням прийомів і засобів порівняльного аналізу коефіцієнтів ліквідності з відповідними середньогалузевими значеннями.

\section{Список використаних джерел:}

1. Єршова, Н.Ю. (2012). Удосконалення методичного підходу до аналізу оборотних коштів як фактору ефективності діяльності промислового підприємства. Вісник Нац. техн. ун-ту «ХПІ» : зб. наук. пр. Темат. вип. : Актуальні проблеми управління та фінансовогосподарської діяльності підприємства. Харків : НТУ «ХП|». № 45 (951). С. 37-46. Вилучено 3 http://repository.kpi.kharkov.ua/handle/KhPI-Press/2967

2. Крупка, Я.Д. (2010). Пріоритетні напрями оптимізації структури капіталу підприємств. Науковий вісник Волинського наиіонального університету імені Лесі Українки, (5), 122127.

3. ПАТ "Арселорміттал Кривий Ріг". Регулярна інфрормація за 2016 - 2018рр. Вилучено з https://ukraine.arcelormittal.com.

4. Побережна, Н.М., Цапун, О.О. (2015). Шляхи підвищення платоспроможності та ліквідності сучасного промислового підприємства. Наукові дослідження розвитку світової економіки: пропозиції, теорії : зб. наук. пр. з актуальних проблем екон. наук. Дніпропетровськ : ВД 
«Гельветика». Ч. 2. С. 72-76. Вилучено з http://repository.kpi.kharkov.ua/handle/KhPIPress/26788 7.

5. Подольська, В.О. (2009). Комплексна оцінка фінансової стійкості підприємства. Науковий вісник Полтавського університету споживчої кооперації України. № 4(35), 136-142.

6. Спицкий, А.В. (2008). Анализ ликвидности баланса: классический и интегральный. Финансовый менеджмент, (1), 28-31.

7. Bolek, M., \& Wilinski, W. (2012). The influence of liquidity on profitability of polish construction sector companies. e-Finanse, 8(1), 38. Retrieved from https://www.econstor.eu/obitstream/10419/66742/1/721357075.pdf

8. Breuer, A., Frumusanu, M. L., Breuer, B. L., \& Manciu, A. (2012). Cash And Liquidity/Liquidity And Liquidity Ratio. Annals-Economy Series, 4, 78-82. Retrieved from http://www.utgjiu.ro/revista/ec/pdf/2012-04.I/11_BREUER\%20Adela.pdf

\section{ОРГАНІЗАЦІЯ МАТЕРІАЛЬНО-ТЕХНІЧНОГО ПОСТАЧАННЯ ВИРОБНИЦТВА (ДЛЯ ВСІХ ПРОМИСЛОВИХ ПІДПРИЕМСТВ)}

Якимів Ірина Богданівна

здобувач вищої освіти економічного факультету Івано-Франківський національний технічний університет нафрти і газу

УКРАЇНА

Підвищення ефективності діяльності промислових підприємств потребує пошуку нових і вдосконалення існуючих підходів до організації матеріальнотехнічного постачання, зокрема застосування логістичного підходу до управління матеріальними потоками [1; 4].

Ефективність застосування логістичного підходу до управління матеріальними потоками на підприємствах зумовлена так: виробництво орієнтоване на ринок, налагоджуються партнерські відносини 3 постачальниками, скорочуються простої устаткування, оптимізуються запаси, скорочується чисельність допоміжних робітників, поліпшується якість продукції, що випускається, знижуються втрати матеріалів, поліпшується використання виробничих і складських площ [4].

Матеріально-технічне постачання покликане обслуговувати виробничу діяльність підприємств і тому перебуває в тісному взаємозв'язку і взаємозалежності 3 виробничим процесом. Однією 3 головних функцій матеріально-технічного постачання $€$ своєчасність і комплектність забезпечення виробництва всіма необхідними йому засобами. Не менш важливою функцією $є$ постачання матеріалів потрібної якості, оскільки від цього залежить якість готової продукції, її ціна та конкурентоспроможність. Процес забезпечення виробництва пов'язаний з необхідністю залучення оборотних коштів, тому однією 3 найважливіших функцій матеріальнотехнічного постачання $€$ прискорення обігу оборотних коштів і зниження їх рівня. Значну роль в підвищенні ефективності діяльності підприємств відіграють витрати обігу, пов'язані з організацією закупівель, транспортування і зберігання матеріалів, максимальне можливе скорочення цих витрат є також 
88 Problèmes et perspectives d'introduction de la recherche scientifique innovante $\bullet$ Volume 1

важливою функцією матеріально-технічного постачання. Із метою забезпечення безперебійності виробничого процесу служба матеріальнотехнічного постачання підприємства має постійно узгоджувати умови постачань з умовами споживання.

Стратегія ж матеріально-технічного постачання на підприємстві покликана на тільки оцінити безперебійність, ритмічність і якість постачань, але i їх ефективність, що виражається в знаходженні таких постачальників, форм і методів постачання, які забезпечили б мінімальні сукупні витрати на придбання і доставку матеріальних ресурсів (рис.1).

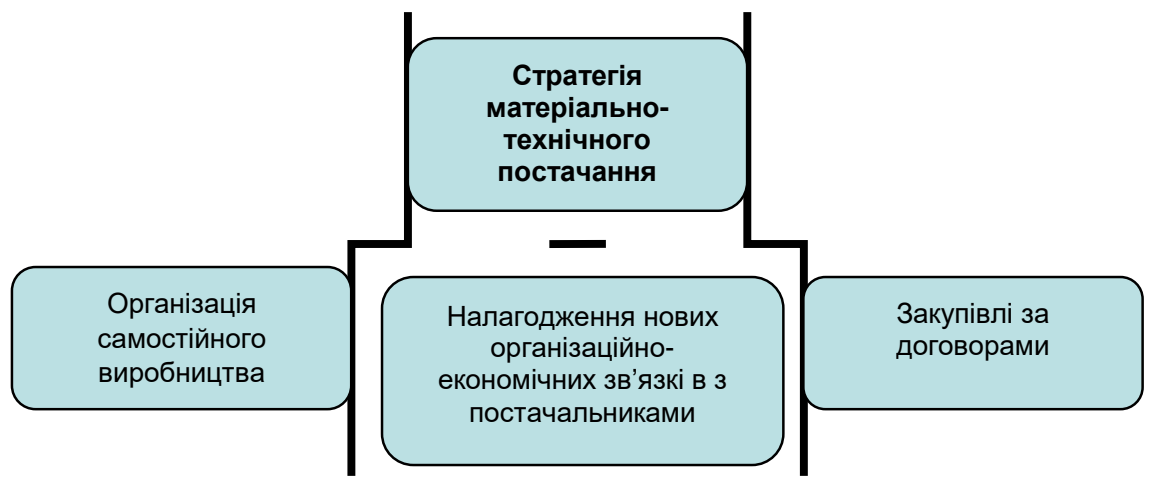

\section{Рис. 1. Складові стратегії матеріально-технічного постачання}

Висновки. Удосконалення управління матеріально-технічним постачанням виробничих підприємств на основі логістичного підходу потребує в подальшому наукового обґрунтування залежностей між показниками ефективності діяльності підприємств та логістичними витратами.

\section{Список використаних джерел:}

1. Мідляр, А.К. (2015) Стратеаія управління матеріально-технічною базою підприємства. Київ.

2. Васюта, В.Б. \& Кирпань, А.Г. Підвищення ролі матеріально-технічної бази як фактор ефективного фуннкиіонування підпиємства. Вилучено з: http://www.rusnauka.com/39_VSN_2014/Economics/10_182500.doc.htm.

3. Карпій, Т.В. \& Лазученкова, Л.С. (2004) Економіка, організація і планування промислового виробництва. Мінськ: Дизайн ПРО.

4. Заїнчковський, А.О. (2017). Теоретичні аспекти та методологічні передумови визначення ефективності виробництва, (33), 106 - 109. 


\section{ОРГАНІЗАЦІЯ ТОВАРОПОСТАЧАННЯ ТА ШЛЯХИ ЗНИЖЕННЯ ВИТРАТ ТОРГОВЕЛЬНОГО ПІДПРИЄМСТВА}

Поповський Олег Юрійович

здобувач освітнього ступеня «магістр» фракультету економіки, менеджменту та права

Вінницький торговельно-економічний інститут КНЕТУ

УКРАÏHA

Торгівля - це одна з найважливіших сфер економічної діяльності, від якої значно залежить якість життя людини, розвиток економіки та її конкурентоспроможність у глобалізованому світі. Актуальність теми статті зумовлена тим, що кількість торгівельних підприємств, як оптових, так і роздрібних щороку збільшується. А тому головним завданням ефективної діяльності торгівельних підприємств залишається оптимізація витрат, оскільки саме витрати посідають чи не найголовніше місце у формуванні прибутку підприємства, розвитку матеріально-технічної бази підприємств торгівлі, поліпшення рівня обслуговування споживачів та посилення конкурентоспроможності підприємства.

Вагомий внесок у вивчення питань планування, нормування, аналізу та оптимізації та різних аспектів ефективності використання ресурсів зробили такі відомі економісти, як Баканов М. І., Капелюш С. М., Шеремет А. Д., Шелегеда Б. Г. та інші.

За сучасних умов економічний світогляд змінюється і поступово зумовлює переосмислення підходів до розуміння сутності витрат їх планування, аналіз прогнозування та оптимізації висвітлено в роботах Стоянової О. С., Балабанова І. Т., Мазаракі А. А., Ушакової Н. М., Бланка І. О. та ін.

Мета статті полягає у визначені основних шляхів удосконалення оптимізації витрат торгівельного підприємства, виявленні резервів зниження витрат торгівельних підприємств, пошуку непродуктивних витрат, що дає змогу підвищити рентабельність підприємства.

Будь-яка діяльність супроводжується витратами, які утворюються у процесі формування та використання ресурсів для досягнення мети підприємства. Останнім часом дедалі більше уваги приділяють економії та оптимізації витрат торгівельного підприємства, оскільки в умовах ринку управління витратами ставить за мету досягнення такої величини, що дасть змогу розширити їх можливості у збільшенні обсягів товарообігу та прибутку за високої якості обслуговування покупців.

Товаропостачання роздрібної торговельної мережі - це комплекс комерційних і технологічних операцій, спрямованих на доведення товарів до роздрібної торговельної мережі в кількості та асортименті, що відповідають попиту населення.

Товаропостачання роздрібної торговельної мережі з погляду теорії систем потрібно розглядати як складну динамічну систему, яка має свою морфологічну та функціональну структуру, основною цільовою метою якої $€$ 
безперебійне доведення до роздрібної торговельної мережі товарів, необхідних для задоволення попиту населення. При цьому морфологічна структура даної системи формується сукупністю взаємозв'язаних і взаємодіючих між собою суб'єктів даної системи, якими є джерела товаропостачання (і окремі постачальники товарів), транспортні підприємства й організації (перевізники товарів, які забезпечують просторове переміщування товарів у процесі товаропостачання) і роздрібні торговельні підприємства, які є кінцевими пунктами завезення товарної маси (яка виступає як основний об'єкт системи товаропостачання).

Характеристику найважливіших напрямів раціоналізації й економії витрат торгівельного підприємства наведено на рисунку.

Розроблено пропозиції щодо оптимізації витрат обігу торгівельного підприємства, а саме витрат транспорту, оскільки в умовах ринку управління транспортними витратами ставить за мету досягнення такої їх величини, що дасть змогу розширити його можливості в збільшенні обсягів обігу та прибутку за належної якості обслуговування покупців.

До продуктивних витрат обігу належать:

1. Витрати зберігання - тобто витрати уречевленої і живої праці та зберігання різних видів запасів (на будування складів, перевірку, сортування, упаковку товарів, на оплату праці робітників складського господарства).

2. Витрати транспорту - тобто витрати на перевезення товарів 3 місць виробництва до місць споживання. Праця на транспорті $€$ продуктивною тією мірою, у якій вона безпосередньо обслуговує перевезення товарів. Витрати транспортування (транспортні витрати) складаються з витрат на переміщення вантажів між географічно роз'єднаними об'єктами і витрат на управління запасами в дорозі та їх утримання.

У товаропостачанні роздрібної торговельної мережі виділяються такі основні заходи (стадії процесу товаропостачання): визначення потреби в товарах; вибір джерел товаропостачання і постачальників товарів; встановлення раціональних схем постачання; укладення угод на постачання товарів (договорів поставки, купівлі-продажу товарів); оперативний контроль за виконанням договорів поставки; вибір форм товаропостачання; визначення раціональної частоти доставки й оптимальних розмірів партій завезення товарів; організація доставки товарів у магазини; приймання товарів і його документальне оформлення.

Для підприємств достатньо потужних торговельних систем 3 великою кількістю пунктів продажу товарів передумовою забезпечення цієї мети $є$ дотримання принципу централізації товаропостачання, який передбачає здійснення товаропостачання магазинів силами і засобами постачальників, без відволікання працівників магазинів та інших пунктів роздрібного продажу товарів для виконання технологічних операцій із завезення товарів. При цьому з працівників роздрібної торгівлі не знімається відповідальність за комерційні аспекти організації товаропостачання. 
Напрями економії та оптимізації витрат торгівельного підприємства

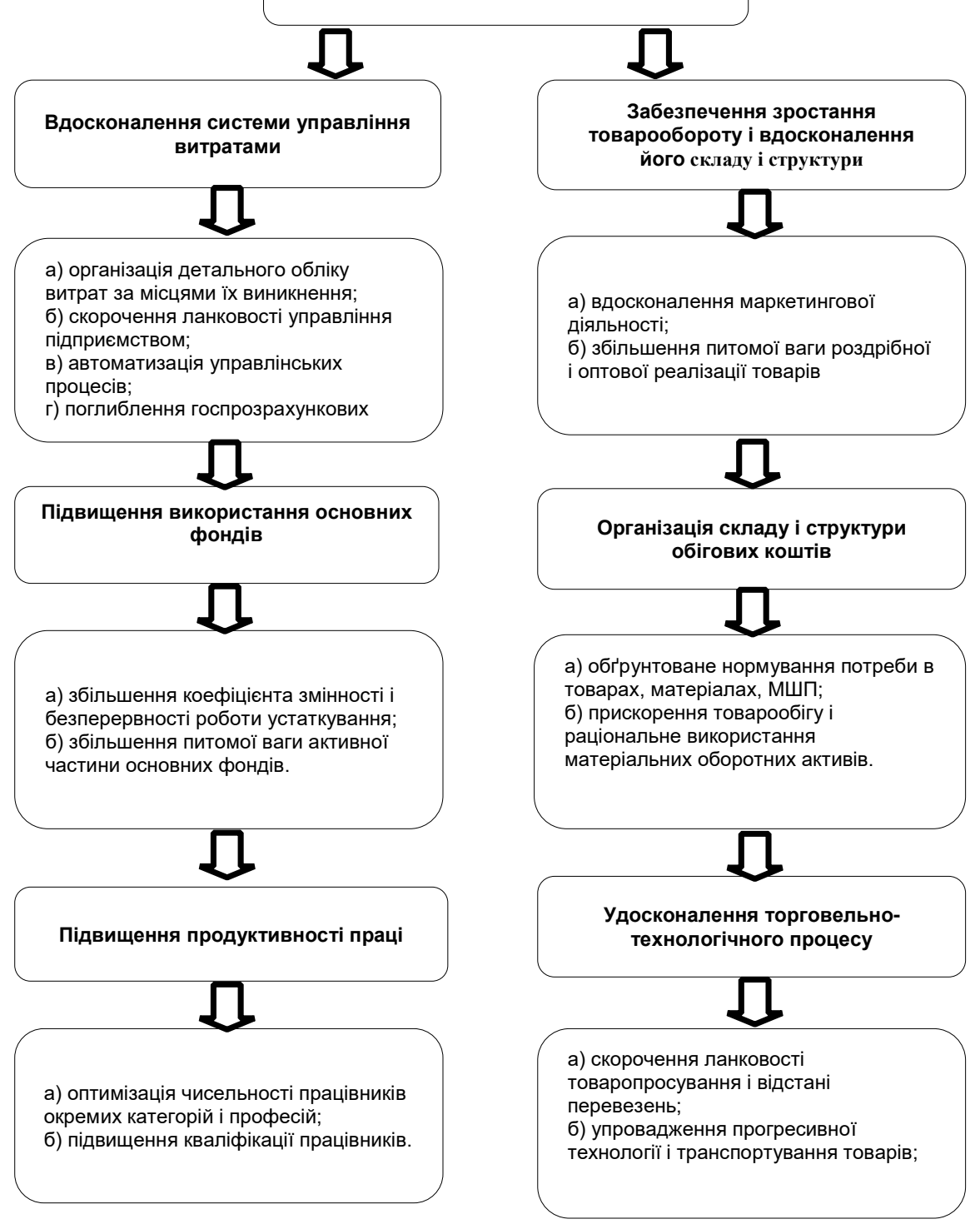

Рис. 1. Характеристика найважливіших напрямів оптимізації та економії витрат 
Для раціональної організації процесу товаропостачання торговельним підприємствам доцільно здійснювати його на основі розроблених комерційною службою планів товарного забезпечення і завезення товарів у магазини.

Раціональна організація постачання роздрібної торговельної мережі 3 урахуванням наведених вимог має базуватися на принципах плановості, безперебійності, ритмічності, оперативності, технологічності та економічності.

1. Принцип плановості товаропостачання передбачає завезення товарів у магазини за графіками, які визначають раціональну частоту, періодичність доставки окремих товарів і оптимальні розміри партій, що підлягають завезенню в торговельні підприємства.

2. Принцип безперебійності товаропостачання полягає в регулярному завезенні товарів у пункти продажу в кількості та асортименті, які унеможливлюють перебої в торгівлі ними.

3. Принцип ритмічності товаропостачання полягає в завезенні товарів через визначені (як правило - рівні) проміжки часу. Завдяки цьому принципу не допускаються відхилення торговельних підприємств від установленого асортиментного профрілю, утворення наднормативних товарних запасів і створюються передумови для раціональної роботи постачальників товарів.

4. Принцип оперативності товаропостачання передбачає завезення товарів у роздрібну торговельну мережу з періодичністю, яка відповідає динаміці роздрібного продажу товарів, його сезонних та інших коливань.

5. Принцип технологічності товаропостачання передбачає застосування прогресивних технологічних рішень на всіх етапах та ланках товаро просування, включаючи транспортні, оптові і роздрібні торговельні підприємства. Основним напрямом забезпечення цього принципу $\epsilon$ впровадження прогресивних технологічних рішень на основі застосування пакетно-модульних і контейнерних систем доставки товарів, що забезпечує індустріалізацію товаропостачання роздрібної торговельної мережі.

6. Принцип економічності товаропостачання передбачає мінімізацію коштів на організацію закупівель, завезення і зберігання товарів. Одним із можливих напрямів забезпечення цього принципу є оптимальне використання парку транспортних засобів, які застосовуються для завезення товарів від постачальників до роздрібної торговельної мережі, механізація завантажувально-розвантажувальних робіт, правильне та вчасне оформлення документів з відпуску та приймання товарів.

Отже, діяльність будь-якого торгівельного підприємства з моменту його створення пов'язана з різними видами витрат, тому саме витрати посідають чи не найголовніше місце у фрормуванні прибутку підприємства. Потрібно здійснювати аналіз усіх показників господарської діяльності підприємства 3 метою отримання можливості визначення резервів скорочення витрат торгівельного підприємства. Оптимізація транспортних витрат не тільки дасть змогу скоротити транспортні витрати та підвищити прибуток підприємства, а й дасть змогу раціонально та доцільно здійснювати управління процесами транспортування та обслуговування споживачів. 


\section{Список використаних джерел:}

1. Апопій, В. В. (2009). Організація торгівлі. (3-е видання). Київ: Центр учбової літератури.

2. Бланк, И. А. (2004). Торговий менеджмент. Київ: Центр навчальної пітератури.

3. Ковальчук, І. В. (2008). Економіка підприємств. Київ: Знання.

4. Мазаракі, А. А. (2006). Торговельне підприємництво: стратегія, політика, конкурентоспроможність. Київ: КНТЕУ.

5. Пономарьова Ю. В. (2003). Логістика: навчальний посібник. Київ: Центр навчальної літератури.

6. Положення (стандарт) бухгалтерського обліку 16 «Витрати». Вилучено 3 http://zakon4.rada.gov.ua/laws/shav/z0027-00.

\section{ОСНОВНЫЕ ФАКТОРЫ МОТИВАЦИИ ЦИФРОВЫХ КОЧЕВНИКОВ}

Андрушой Кристина Николаевна
получатель высшего образования экономико-правового факультета
Одесский национальный университет имени И.И. Мечникова
Фучеджи Наталия Фёдоровна
получатель высшего образования экономико-правового факультета
Одесский национальный университет имени И.И. Мечникова

Научный руководитель: Жмай Александр Владимирович старший преподаватель кафедры менеджмента и инноваций Одесский национальный университет имени И.И. Мечникова

УКРАИНА

В XXI веке происходят серьезные и глобальные перемены, связанные с прорывом в развитии цифровых технологий, революцией в информационном пространстве, а также ускорением процессов глобализации и цифровизации экономики. Информация стала ключевым ресурсом в общественной и хозяйственной жизни [1].

Очень популярной становится работа онлайн. Но реальная ситуация такова, что индивидуумы стремятся не к оседлому образу жизни, работая удаленно в электронном коттедже, а к максимальной географической мобильности и постоянному подключению к сети. Поэтому все большую актуальность в качестве предмета исследования приобретают цифровой номадизм или цифровое кочевничество как глобальное явление сетевого информационно-коммуникативного общества.

Понятие цифровой кочевник (цифровой номад, он же digital nomad) появилось в США еще в 1997 году, но распространение получил только в последнее десятилетие. Цифровые кочевники - это социальная группа людей, которые работают удаленно через интернет и не привязаны к конкретному месту жительства в процессе выполнения своих профессиональных обязанностей [2].

В зависимости от формата работы кочевников делят на три группы: 
- фрилансеры, которые трудятся над единичными проектами;

- предприниматели, которые создают и развивают стартапы;

-удаленные сотрудники, которые заняты на постоянной основе в компаниях [2].

Первыми представителями цифровых номадов были программисты, которые уезжали в теплые страны для работы в зимний период. В дальнейшем это трансформировалось в отдельное движение, представители которого предпочитали «кочевничество» по миру. Со временем к ним присоединились веб-разработчики, интернет-маркетологи, блогеры, дизайнеры и другие [3].

На данный момент, цифровых кочевников не так много и поэтому изучение и формирование специальных методов управления, корпоративных культур и способов мотивации данной социальной категории находятся на начальном этапе своего развития. Но, как писал голландский предприниматель и ITномад Питер Левелс, уже к 2035 году цифровых кочевников станет гораздо больше, примерно один миллиард [4]. Поэтому анализ данной проблемы является очень важным уже сегодня.

С переходом к цифровому обществу появляется все больше работников, которые выступают цифровыми кочевниками. При этом появляется необходимость в формировании новых подходов к управлению такими сотрудниками, поскольку меняется мотивация последних. Эти изменения связанны с тем, что предпочтения и приоритеты индивидуумов быстро возрастают и сменяют друг друга, поэтому руководителю необходимо применить такие мотивационные приемы, которые удовлетворили бы потребности подчиненных. Меняется также система ценностей и взглядов человека, он начинает мыслить по-другому, под иным углом воспринимать мир. Теперь первичными потребностями для него становятся Интернет и постоянное наличие подключения к сети. Современный «кочевник» приходит к осознанию того, что у него нет определенного пространства существования и однозначных правил восприятия мира, у него нет ничего постоянного, это все порождает чувство тяготы от предоставленной ему свободы [5].

Что может выступать мотивацией цифровых кочевников продолжать свою деятельность, несмотря на переменчивые условия жизни и работы, а также постоянный физические и эмоциональные испытания? Во-первых, это возможность работать из любой удобной точки мира, что расширяет кругозор путем погружения в иную культуру и тем самым способствует приобретению, а также накоплению опыта, который в будущем поможет адаптироваться к различным условиям жизни. Во-вторых, это способность преодолеть свои страхи и языковые барьеры, что усовершенствует индивидуума как личность и помогает ему свободно коммуницировать с другими, при этом преодолевая свои внутренние преграды. Кочевой образ жизни дисциплинирует путем постоянной необходимости следить за временем и строить планы, что в итоге приводит к большей организованности, а следовательно - и к продуктивности. Еще одним способом мотивации может выступить создание специальных приложений для цифровых кочевников, что в дальнейшем объединит представителей этой категории и создаст некую корпоративную культуру, которая будет способствовать формированию общей системы 
ценностей. Это все предупредит появление одной из главных проблем их деятельности - тотального одиночества, при котором все чувства, эмоции и отношения заменяются симуляциями.

Феномен цифрового кочевничества является относительно новым, однако он активно развивается. Поэтому очень важно уже сегодня исследовать эти процессы, и на основании полученных данных формировать подходы к управлению, которые будут лучше всего соответствовать особенностям цифровых кочевников.

\section{Список используемых источников:}

1. Савина, Т. Н. (2018). Цифровая экономика как новая парадигма развития: вызовы, возможности и перспективы. Финансы и кредит, (3), 579-590. Изъято из https://cyberleninka.ru/article/n/tsifrovaya-ekonomika-kak-novaya-paradigma-razvitiya-vyzovyvozmozhnosti-i-perspektivy.

2. Кравченко, В. (2017). Я хочу стать цифрровым кочевником. С чего начать? Изъято из https://rb.ru/opinion/hochu-stat-kochevnikom/.

3. Борисова, Е. (2019). Цифровые кочевники: как они изменят индустрию путешествий? Изъято из $\mathrm{https}: / /$ imtovi.ru/who_are_digital_nomads/.

4. Levels.io (2015). There will be 1 billion digital nomads by 2035. Изъято из https://levels.io/futureof-digital-nomads/.

5. Яковлева, Е. Л., Селиверстова, Н. С. \& Григорьева, О. В. (2017). Концепция электронного кочевника: риски развития цифровой экономики. Актуальные проблемы экономики и права, (4), 226-241.

\section{ОСОБЛИВОСТІ ДОСЛІДЖЕННЯ РИНКУ ПОБУТОВОЇ ТЕХНІКИ ТА ЕЛЕКТРОНІКИ (НА ПРИКЛАДІ КОМПАНІЇ «РЕКОРД»)}

Овецька Ольга Валеріївна кандидат економічних наук, доцент, доцент кафедри менеджменту і адміністрування Івано-Франківський національний технічний університет нафоти і газу

Атавін Андрій

магістр Інституту економіки і менеджменту Івано-Франківський національний технічний університет нафоти і газу УКРАÏHA

За даними дослідження GfK TEMAX Україна [1] за другий квартал 2019 року, продажі гаджетів, побутової техніки та електроніки в нашій країні продовжують впевнено зростати. Загальний обсяг продажів на українському ринку технічних споживчих товарів зріс на 15\% порівняно з аналогічним періодом минулого року. Найбільший приріст показали сектори великої та малої побутової техніки: $+22 \%$ та $+23 \%$ відповідно; сектор офрісної техніки зріс на $+21 \%$ порівняно з аналогічним періодом минулого року. В той же час драйвером ринку залишається сектор “Телеком”, питома вага якого склала 
більше ніж 7,7 млрд грн. На другому та третьому місцях - велика побутова техніка та IT із результатом у 4,7 та 3,9 млрд грн. відповідно.

Компанія «Рекорд», представлена на роздрібному ринку побутової техніки та електроніки м. Івано-Франківська, характеризується позитивною динамікою основних показників діяльності [2], посідає позицію активного учасника ринку, проте за результатами аналізу конкурентних переваг, суттєво програє основним конкурентам (магазини «Tіп Топ», «Бомба», «Life»), які розвивають у пріоритеті онлайн-продажі.

Як показав проведений аналіз, серед фракторів, які мають найбільш негативний вплив на конкурентоздатність досліджуваного підприємства формування асортиментної політики.

За результатами XYZ-аналізу розподіл основних асортиментних груп компанії виглядає наступним чином: асортиментні категорії смартфони і телефони, телевізори та аудіотехніка, техніка для дому, належать до групи $\mathrm{X}$ (показник варіації від 0 до 10\%) як товари з найбільш стійкими обсягами продажів; всі інші групи (техніка для кухні, смарт-гаджети, посуд, інструменти, «дім та сад») віднесені до категорії Y як товари з прогнозованими, але мінливими обсягами продажів (показник варіації від 10 до 25\%). ТзОВ «Рекорд» немає категорій, які б належали до групи Z (показник варіації понад $25 \%$ ), що пояснюється тим, що фактор сезонності попиту компенсується в сумі за рік і є досить позитивним для компанії.

Отже, високий рівень невизначеності та динамічності складових маркетингового середовища зумовлює потребу у достовірній, оперативній і чіткій інформації, що вимагає систематичного проведення маркетингових досліджень у роздрібній торгівлі, арсенал методів яких, загальних та специфічних, дозволяє отримати достатню кількість інформації для прийняття ефективних управлінських рішень [3]. Проте, структура інформаційного забезпечення процесу прийняття ділових рішень визначається специфікою, складністю, структурою маркетингового середовища компанії, що, в свою чергу, визначає основні напрямки маркетингових досліджень [4].

\section{Список використаних джерел:}

1. У II кварталі 2019 року продавці побутової техніки та електроніки заробили більше 21 млрд. грн. (Дослідження Асоціації рітейлерів України). (2019). Вилучено 3 https://rau.ua/novyni/2019-rynok-tehniky-ta-elektroniky/.

2. Про компанію Рекорд - техніка для дому. (2019). Вилучено 3 http://www.rekord.f.ualabout_us.

3. Жегус, О. В. \& Михайлова, М. В. (2009). Методи маркетингових досліджень у роздрібній торгівлі. Економічна стратегія і перспективи розвитку сфрери торгівлі та послуг, (2), 622-629.

4. Жегус, О.В. \& Парцирна, Т.М. (2016). Маркетингові дослідження. Х.: ФОП Іванченко І.С. 


\section{ОСОБЛИВОСТІ НАУКОВО-ДОСЛІДНОЇ ДІЯЛЬНОСТІ МУЗЕЇВ}

Пономарьова Ганна Вікторівна

Вінницький торговельно-економічний інститут КНТЕУ

Науковий керівник: Малюта К. Г.

асистент

Вінницький торговельно-економічний інститут КНТЕУ

УКРӒ̈HA

Наукові дослідження в будь-якому музеї $є$ обов'язковою умовою його функціонування, оскільки їх результати визначають рівень науково-фондовій, експозиційній, просвітницької та освітньої діяльності музею. Музеї самі по собі входять у систему науково-дослідних установ. Комплектування музейних зібрань обов'язково зв'язано з проведенням досліджень. У процесі формування колекцій музей знаходить предмети музейного значення, що документують процеси і явища, що протікають у суспільстві і природі. Це в свою чергу поповнює фонди відповідними матеріалами і тим самим не тільки розширює базу науки, але й допомагає одержувати нові, раніше не відомі знання [1].

Науково-дослідна діяльність - це один з провідних напрямів діяльності музеїв, пов'язаних з накопиченням, обробкою та введенням у науковий та загально культурний оборот матеріальних і нематеріальних об'єктів спадщини. До науково-дослідної діяльності наукознавство відносить «особливий вид людської праці, що представляє сукупність процесів добування або пошуку інформації, процес дослідження, опрацювання, комплектування, аналіз, експонування, реставрація та консервація». Все це можна віднести і до напрямів науково-дослідної роботі в музеї. До якої б області ні відносилася дослідницька діяльність, її результатом завжди є нова інформація, отримана при вивченні того або іншого об'єкта. У ході аналізу й обробки ця нова інформація в сполученні з уже відомими про даний об'єкт зведеннями перетвориться в принципово нові наукові знання про явища і процеси, що відбуваються в природі і суспільстві [2].

Для проведення будь якого наукового дослідження потрібно мати певний об'єкт чи предмет дослідження. У фондах музеїв під охороною перебувають найрізноманітніші предмети і об'єкти природи, матеріальної та духовної культури людства. У музеєзнавстві цей спектр пам'яток традиційно розмежовують за окремими критеріями. Так, виділяють два класи пам'яток: рухомі та нерухомі предмети та об'єкти. Види музейних предметів виділяються на основі спільності однієї чи декількох ознак якими можуть бути, наприклад, матеріал, функціональне призначення, техніка виготовлення предмета або ж поєднання окремих ознак. Також музейні предмети поділяються за типами.

Наприклад, до речових предметів відносяться знаряддя праці, інструменти, зброя, одяг, прикраси, предмети побуту. Образотворчі музейні предмет представлені оригінальними творами іконопису, станкового і монументального живопису, скульптурами, графікою, декоративно-ужитковим мистецтвом, різноманітними видами народної творчості. Письмові музейні предмети 
являють собою рукописи, документи, першодруки книг, журналів, газет, листівок, афіш. Музейні предмети, що за допомогою спеціальних технічних засобів зберігають звуки, статичні та динамічні зображення називають фонічними. Також існують науково-технічні музейні предмети, до яких відносяться інструменти, машини, устаткування, а також документи про винаходи і наукові відкриття, меморіальні, тобто предмети і матеріали, пов'язані з життям і творчістю відомих людей, меморіальні знаки, надгробки, нумізматичні - колекції монет, медалей, орденів, жетонів, різних відзнак, та природні - разки матеріалів, ґрунтів, колекції рослин, опудала звірів, мокрі і сухі зоологічні препарати [3].

Знаючи, якими бувають музейні предмети, ми можемо розглянути, які етапи вивчення вони проходять. Перший етап має назву атрибуція. На цьому етапі виявляються основні притаманні предмету ознаки, які визначають назву, призначення, матеріал та техніку виготовлення, авторство, хронологію та географрію створення певного предмету. На другому етапі предмет проходить класифікацію та систематизацію. I нарешті третій етап - інтерпретація, тобто представлення цього предмета.

Отже, музей можна порівняти з кіноіндустрією, де готову експозицію можна порівняти з готовим фільмом, який ми можемо бачити, а науково-дослідна робота - це та робота, яка залишаться поза кадром, наприклад, розробка сценарію, пошиття костюмів, написання музики. Так само, як кіно не може існувати без роботи за кадром, не може існувати музей, без науково-дослідної роботи.

\section{Список використаних джерел:}

1. Міхно, О.П. (2019). Комуникационное пространство Педагогического музея Украины, (2), 168-170.

Вилучено http://lib.iitta.gov.ua/717802/1/\%D0\%9C\%D1\%96\%D1\%85\%D0\%BD\%D0\%BE_\%D0\%9C\%D0 \%B0\%D1\%82\%D0\%B2\%D1\%96\%D0\%B9\%D1\%87\%D1\%83\%D0\%BA_2019_Komunikacionno e\%20prostranstvo\%20Pedagogicheskogo\%20muzeya\%20Ukraini.pdf.

2. Воронова, Л.М. \& Мартем'янова, Н.С. (2018). Науково-дослідна робота харківського історичного музею в перше повоєнне десятиліття, (52), 40-52. Вилучено 3 file:///C:/Users/User/Downloads/124913-266260-1-SM\%20(4).pdf

3. Рутинський, М. Й. \& Стецюк, О. В. (2008). Музеєзнавство. Київ: Знання. 


\title{
ОСОБЛИВОСТІ ОБЛІКУ ПОТОЧНИХ ФІНАНСОВИХ IНВЕСТИЦІЙ
}

\author{
Сергійчук Надія Анатоліївна \\ здобувач вищої освіти економічного факультету \\ Національний університет біоресурсів і природокористування України
}

Воляк Леся Романівна канд. екон. наук, старший викладач кафедри статистики та екон.аналізу Національний університет біоресурсів і природокористування України

Сьогодні все більшої популярності набуває інвестування вільних коштів у певні підприємства, компанії, цим самим стимулюючи їх розвиток і при цьому отримуючи відповідні дивіденди. Поточні фрінансові інвестиції мають більш тактичне значення, адже можуть бути вільно реалізовані в будь-який момент та використовуються не більше одного року, а отже прибуток можна отримати в найкоротший термін, що приваблює інвесторів.

Вітчизняні вчені, такі як Ф.Ф. Бутинець, Б.І. Валуєв, Є. В. Мних, В.В. Сопко та інші займалися дослідженнямтеоретичних та практичних розробок обліку поточних фрінансових інвестицій, адже саме належна його організація дозволяє здійснювати аналіз та контроль ефективності та доцільності отриманого капіталу.

Основним завданням обліку поточних фрінансових інвестицій є їх об'єктивна оцінка, повне відображення та внесення до облікових регістрів операцій, які 3 ними пов'язані, узагальнення у звітності. Це дозволяєзабезпечувати інформацією зацікавлених осіб та здійснювати ефективне управління.

Відображення «життєвого циклу» поточних фінансових інвестицій в обліку складається з наступних етапів: визнання, первісна оцінка, відображення на рахунках бухгалтерського обліку, переоцінка на дату балансу; визнання, оцінка та відображення доходу, розкриття інформації у фінансовій звітності, припинення їх визнання та списання [2].

При отриманні прав власності на поточні фрінансові інвестиції здійснюється їх визнання, взяття на облік та первісна оцінка, яка формується за їх собівартістю та особливостями активів, що надаються в обмін. Для відображенні в обліку призначений рахунок 35 «Поточні фрінансові інвестиції», за дебетом якого відображається надходження чи збільшення вартості, за кредитом, відповідно, навпаки. Аналітичний облік $є$ індивідуальним для кожного підприємства залежить від видів фінансових вкладень, об'єктів інвестування тощо [3].

Вартість короткострокових фінансових інвестицій відносно стабільна, проте при можливій зміні їх вартості необхідно здійснити їх переоцінку на дату складання балансу за відповідним методом: участі у капіталі, справедливої вартості, амортизованої собівартості, собівартості з урахуванням зменшення їх корисності. 
Дохід за поточними фрінансовими інвестиціями визнається із застосуванням методу нарахування, коли признаються результати фрактичного здійснення інвестиційних операцій, що призводять до зростання активу, або зменшення зобов'язання. Бухгалтерську інформацію про стан інвестиційної діяльності можна знайти в Балансі та Примітках до фінансової звітності [1].

Завершальною сходинкою є припинення визнання інвестиції та ії списання у зв'язку з її реалізацією, закінченням терміну обліку тощо.

Слід зазначити, що не менш важливим $є$ затвердження в обліковою політикою своєчасне та точне документування всіх наведених вище операцій. Розробка первинних документів та постійний їх контроль забезпечують повне та достовірне висвітлення інформації в облікових регістрах, Головній книзі, що згодом полегшує формування фінансової звітності.

Отже, зважаючи на пожвавлення інвестиційних вкладень, зокрема короткострокових, для кожного підприємства важливо впровадити відповідну обліково-аналітичну політику щодо таких залучень. Належне відображення в бухгалтерському обліку дозволяє прийняти ефективні управлінські рішення, які стосуються використання поточних фінансових інвестицій.

\section{Список використаних джерел:}

1. Махота, А.В.(2014) Бухгалтерське відображення фрінансових інвестицій приватних підприємств (огляд). Науковий вісник Херсонського державного університету, 209-214.

2. Про затвердження Положення (стандарту) бухгалтерського обліку 12 «Фінансові інвестиції» (Наказ Міністерства фінансів України). №91 від 26.04.2000. Вилучено 3 https://zakon.rada.gov.ua/laws/main/z0284-00.

3. Інструкція про застосування Плану рахунків бухгалтерського обліку активів, капіталу, зобов'язань і господарських операцій підприємств і організацій (Наказ Міністерства фінансів України). №291 від 30.11.1999. Вилучено з https://zakon.rada.gov.ua/laws/show/z0893-99.

DOI 10.36074/29.11.2019.v1.07

\section{ОЦІНКА РИНКУ ГОТЕЛЬНО-РЕСТОРАННИХ ПОСЛУГ У MICTI ВІННИЦЯ}

Задорожнюк Денис Павлович

здобувач вищої освіти фракультету торгівлі, маркетингу та сфери обслуговування

Вінницький торговельно-економічний інститут КНТЕУ

Мазуркевич Ірина Олександрівна

канд. екон. наук, доцент кафедри туризму та готельно-ресторанної справи

Вінницький торговельно-економічний інститут КНТЕУ

УKPAÏHA

На сучасному етапі готельно-ресторанне господарство $€$ одним 3 найприбутковіших сфер здійснення туристичної діяльності не тільки у межах країни, а й на рівні окремо взятого регіону. Вінниччина завдяки вигідному географічному положенню, сприятливому клімату, різноманітному рельєфу, 
унікальному поєднанню природно-рекреаційних ресурсів та культурноісторичної спадщини, має всі найнеобхідніші ресурси, що формують умови для високоприбуткового та ефективного розвитку туристичної сфери регіону.

Проте туристичний потенціал Вінницької області на сьогодні не є повністю розкритим. Основними причинами «обмеження» готельно-ресторанного бізнесу у регіоні $є$ відсутність відповідної інфраструктури для обслуговування. Наприклад, відсутність фітнес-центрів, автостоянок, конференц-залів, а також орієнтація на двомісні номери у готелях, що не відповідають міжнародним стандартам. Окремим фрактором стримування подальшого розвитку та прибутковості сфери ресторанного та готельного бізнесу $€$ низький рівень економічного забезпечення населення в області.

Вінницька область має позитивний туристично-рекреаційний потенціал, що створює великі перспективи для розвитку саме готельно-ресторанної індустрії. Прослідковуючи тенденції кулінарних традицій світових кухонь активно з'являються та розвиваються тематичні ресторани у Вінниці. На сьогодні гості міста можуть відвідати заклади та скуштувати страви грузинської, італійської, японської, американської та європейської кухонь.

Так вже 1 грудня 2020 року у Вінниці планують відкрити анонсовий ресторан «АССА», який поєднає в собі грузинську та кримськотатарську кухню. Цікавим $\epsilon$ те, що ресторатор закладу, Валерій Сиверчук, анонсував про «відкриті проробки», де кожен охочий може долучитись до «становлення ресторану» [1].

Минулий 2018 рік став одним із найцікавіших в гастрономічному плані, тому станом на 2019-2020 роки особливу популярність отримали моноформати в ресторанному бізнесі - маленькі заклади з їжею за фріксованою ціною, або ж заклади, що спеціалізуються на дуже лаконічному меню. Черговим «дитям» сім'ї ресторанів Вінниці стане інший моноформат «Анчоусная» - заклад, який матиме свою специфіку та пропонуватиме рибне меню за доступними цінами [1].

Також слід звернути увагу на зміну характеру та структури діяльності ресторанного господарства. Стійкі позиції в обслуговуванні клієнтів займає кейтеринг - послуга приміщення сервісу із закладів ресторанного господарства до місця проведення заходу. Сьогодні кожен ресторан на Вінниччині відрізняється від інших власним стилем, кожен став візитною карткою гостинності міст регіону та певною формою проведення дозвілля. Основним напрямком розвитку ресторанної сфери $є$ надання он-лайн послуг замовлення у мережі Інтернет та вдосконалення форм розрахунків за ресторанні послуги, зокрема кредитні картки.

В липні 2019 року у Вінниці було вперше проведено дослідження туристичної привабливості міста Соціологічною агенцією «Fama». За оцінкою даного дослідження, більшість відвідувачів прибувають до міста з метою відпочинку, розваг, огляду міста та його пам'яток. Внаслідок цього середні витрати відвідувачів припадають на проживання та харчування, а отже збільшились надходження до бюджету від туристичного збору. Порівняти обсяги туристичних надходжень можемо за допомогою графіка на рисунку 1. Так, за 10 місяців 2018 року туристичний збір склав 275,481 тис.грн., тоді як за 10 місяців 2017 року - 235,122 тис.грн., а за аналогічний період 2016 року - 
172,061 тис. грн. Особливостями готельного бізнесу у Вінницькій області $€$ орієнтація на Європейські сервісні стандарти і стрімкий перехід до них.

Аналізуючи саме готельне господарство Вінницького регіону, слід зазначити, що привабливість даного сектору не викликає сумнівів, проте матеріально-технічна база об'єктів в більшості не відповідає сучасним вимогам і потребує значних інвестицій для модернізації та переоснащення. У самому місті Вінниці станом на 2019 рік функціонують 50 готелів. Більша частина готелів Вінницької області орієнтовані на тризірковий стандарт, який, до речі, $є$ базовим за кордоном. Готельний ринок Вінницької області щоденно стикається з низкою проблем. Однією з таких проблем є слабкість внутрішньої конкуренції (яка пояснюється відсутністю вільних засобів і високими податковими ставками, через що складно забезпечити економічну стабільність, максимізувати прибутки, підвищити конкурентоспроможність підприємств індустрії гостинності на ринку готельних послуг), а також відсутність могутніх міжнародних готельних мереж. Низька конкурентоспроможність надання готельних послуг формується рівнем ціни і якістю самих послуг. Через високі податкові ставки (готельний збір) готелі вимушені встановлювати високі ціни. Майже усі Вінницькі готелі $є$ приватними. Зазвичай, вони створені на базі реконструйованих житлових будівель або колишніх гуртожитків. Самі ж власники приватних готелів заявляють, що відкривати великий готель поки що не варто, тому що: по-перше, маленьким легше управляти, а по-друге, у ньому простіше зберігати домашню обстановку. Для заповнення готелів у Вінниці властива певна циклічність: тижнева (з неділі до четверга - затишшя, п'ятниця, субота - пік) та сезонна (сезон роботи фонтану «Roshen»). За наявними даними Державного Комітету Статистики України готелі Вінницької області прийняли у 2016 році - 60 тис. осіб, у 2017 році - 85 тис. осіб. [4] Виходячи з цих даних можна зробити висновок, що готельні заклади у Вінницькій області мають попит і приймають велику кількість туристів [3]. Таким чином, у Вінницькій області розвиток готельноресторанного бізнесу за останні роки є досить стрімким та перспективним. На сьогодні, готельно-ресторанні господарства Вінниччини направлені на вдосконалення та підвищення комфорту, але існує низка проблем за яких розвиток уповільнюється, а саме через низьку купівельну спроможність населення, неякісне обслуговування та національні особливості населення, більшість підприємств стають збитковими, матеріально-технічна база потребує модернізації та переоснащення, але без інвестицій дуже складно це зробити. За минулий 2018 рік ресторанна база Вінниччини зросла в рази, досить багато ресторанів з кухнею різних країн світу, популярними також стали тематичні ресторани та кейтеринг.

\section{Список використаних джерел:}

1. Нові тематичні ресторани Вінниці. Вилучено 3 https://vezha.vn.ua/restoran-assa-tamonoformat-anchousnaya-u-vinnytsi-z-yavlyatsya-dva-novyh-zaklady-harchuvannya/

2. Івашина, Л.Л. (2017). Перспективи та проблеми кейтерингу в Україні. Глобальні та національні проблеми економіки, (17), 314-317

3. Програма розвитку туризму в місті Вінниці на 2016-2020 роки. Вилучено 3 https://www.vmr.gov.ua/Branches/Lists/Tourism/ShowContent.aspx?ID=1 
29 novembre $2019 \bullet$ Bruxelles, Belgique $\bullet 103$

4. Державний комітет статистики україни. Вилучено 3 http://www.ukrstat.gov.ua/druk/publicat/kat_u/2018/zb/11/zb_ru1ch2018.pdf

\section{ПЕРСПЕКТИВИ РОЗВИТКУ ЕКСТРЕМАЛЬНОГО ТУРИЗМУ В УКРАЇНІ}

Гуцол Ольга Миколаївна

здобувач вищої освіти факультету торгівлі, маркетингу та сфери обслуговування Вінницький торговельно-економічний інститут КНТЕУ

Науковий керівник: Малюта Катерина Геннадіївна асистент кафедри туризму та готельно-ресторанної справи

Вінницький торговельно-економічний інститут КНТЕУ

УKPAÏHA

В Україні є безліч можливостей для організації активного й екстремального відпочинку. Екстремальні розваги - це нова конкурентна перевага для будьякого туристичного місця або маршруту. В Україні $є$ багато варіантів для розвитку таких напрямків, проте станом на сьогоднішній день, майже всі вони знаходяться на початковому рівні свого розвитку.

Плануючи свій відпочинок, туристи звертають увагу на багато чинників, наприклад певні визначні місця, побутові зручності або ж особливості клімату. Тепер до цього списку ще входять можливості для активних форм відпочинку (особливо це стосується молоді).

Формуванням попиту на екстремальні розваги є, по-перше, бажання туристів, по-друге, це елемент новизни, по-третє, екстремальні види спорту максимально сприяють викиду зайвої енергії та зняттю стресу, що часто $є$ характерним для людей середнього віку. Активний відпочинок - один із найліпших способів зняття напруги та стресу.

Сучасні туристи надають перевагу подорожам з елементами екстриму. Екстрим - це особливе спонукання душі і тіла викидати якомога більше адреналіну і емоцій.

Якщо моніторити публікації, присвячені даній тематиці, відомо що у Європі близько $30 \%$ відпочиваючих хоча б один раз у тиждень виїжджають на джипсафрарі, рафртинг, екскурсію на яхті тощо. 3 економічним розвитком суспільства збільшується кількість видів відпочинку (в тому числі й екстремального), а також число бажаючих урізноманітнити дозвілля незвичайними враженнями [1].

Політ на повітряній кулі $є$ одним із видів екстремального туризму. Цей вид відпочинку вважається надзвичайно романтичним і видовищним і одночасно не пов'язаний з серйозним ризиком для життя та здоров'я людей. В Україні даний вид туризму поки знаходиться на початковій стадії розвитку.

Для розвитку туристичного повітроплавання в Україні $€$ всі необхідні передумови, насамперед природні. Перспективними вважаються такі місця, як 
Карпати, міста Київ і Львів, які є красивими історичними місцями, Кам'янецьПодільський (з можливістю прольоту під мостом), Асканія-Нова тощо.

І способів політати - безліч. Один з них - параплан, надлегкий літальний апарат. Принцип його польоту такий же, як у планера або дельтаплана. На ньому можна не тільки знижуватися, але і набирати висоту. На сьогоднішній день це один з найбільш дешевих і доступних видів літальних апаратів. Рівень безпеки в парапланеризмі дуже високий - конструкція апарату не дозволить помилитися, навіть якщо захочеш. Непідготовленій людині достатньо усього 20 хвилин інструктажу, щоб зробити свій перший політ [1].

Стрибки $з$ парашутом - відпочинок для екстремальних туристів з гарною фрізичною підготовкою. Цей вид екстриму так само, як і повітроплавання, перебуває на початковій стадії розвитку в Україні. $€$ два головних напрямки розвитку парашутного туризму - стрибки для спортсменів і стрибки для аматорів (туристів). Для тих і для інших (особливо іноземців) пропозиція такої послуги в Україні буде дуже привабливою внаслідок конкурентної ціни в порівнянні із західноєвропейськими країнами [1].

Молодий вид спорту і один з кращих способів екстремально провести час на воді - вейкбординг або вейк - являє собою комбінацію водних лиж і серфінгу. Суть його полягає в катанні на спеціальній дошці, що прикріплена до катера, моторного човна або скутера. Під час катання ви отримуєте не тільки задоволення, але і фрізичне навантаження на свіжому повітрі. Одне 3 найголовніших переваг вейка - простота в навчанні. Займатися можна навіть людям, які не мають абсолютно ніяких навичок катання, чоловікам і жінкам будь-якого віку і навіть дітям.

Покататися на вейкборді в Україні можна в Києві (Труханів острів і парк Дружби народів), Одесі (парк "Екстримальна тяга"), Дніпропетровську (вейкпарк "360", "Сентоза") і в Запоріжжі (вейк-парк Adrenaline Wake)

Сплави по річках - це один з видів спорту, що плавно переходить в екстремальний відпочинок - сплави по річці на спеціальних плавзасобах (рафтах, байдарках, катамаранах) в Україні мають перспективне майбутнє широко використовуватись у плані надання туристичних послуг. Україна покрита густою мережею більших і малих, рівнинних і гірських рік. Це дає можливість активно розвивати в нас водний туризм, а багатство рекреаційних ресурсів та історико-культурна спадщина дозволяє туристам вибрати маршрут сплавів. Рівнинні ріки без крутих порогів і водоспадів (Десна, Дністер, Сіверський Донець, Псел, Ворскла) ідеально підходять для організації спокійних сплавів для новачків і сімейного відпочинку на природі. Для більш активного сплаву підійде Південний Буг, що має нескладні водні перешкоди пороги й перекати. Для найбільш сміливих - спортивні сплави по гірських ріках Карпат (Черемош, Прут, Тиса, та ін.). Тривалість сплавів коливається від дводенних турів вихідного дня до двотижневих [1].

Однак і у водному бізнесі існують свої особливості. По-перше, використовувані при сплавах плавзасоби повинні відповідати високим стандартам якості й безпеки, особливо якщо мова йде про непідготовлених туристів без досвіду керування такими засобами. Головна проблема сучасних українських сплавів саме у використанні деякими операторами неякісних туристичних плавзасобів.По-друге, бізнес, створений тільки на базі водного 
туризму, буде мати яскраво виражену сезонність. Водні розваги - ледве не єдиний вид відпочинку, характерний тільки для літнього сезону [1].

Організація сафарі можлива в тих країнах, де ще можна побачити природу в її первісному вигляді. В Україні налічується 17 природних, 4 біосфрерних заповідники і 12 національних природних парків, у яких дика природа перебуває під охороною держави. Серед них - найбільший заповідник у Європі - Асканія-Нова, у якому можна побачити тварин представників майже всіх континентів планети. Саме тут пропонується єдиний в Україні тур-сафарі - 2,5годинна екскурсія з можливістю сфотографуватися на фоні тварин [1].

На території України є достатньо сприятливі умови і ресурси для розвитку екстремального відпочинку. Але низький рівень розвитку туристичної інфраструктури і соціальних стандартів населення призвів до того, що екстремальний туризм у нас у своєму розвитку відстає від загальносвітових тенденцій. За оцінками багатьох вітчизняних спеціалістів, існує великий потенціал екстремального туризму, який можна буде розкрити з загальним соціально-економічним розвитком держави [2].

На сьогодні важко визначити загальну кількість екстремальних видів туризму. Це зумовлено широким підходом до впровадження екстремальних розваг в різних сфрерах людської діяльності. В Україні перспективним вважається розвиток таких видів екстремального туризму, як польоти на повітряних кулях, парашутизм, спелеологія, різні види сафарі та рафртинг.

При організації та проведенні екстрім-турів виникає значна потенційна небезпека для життя і здоров'я учасників. Важливою проблемою розвитку екстремальних видів відпочинку $\epsilon$ забезпечення цього виду діяльності висококваліфікованими спеціалістами-професіоналами з попереднім досвідом роботи. Доцільно було би залучати до організації цього виду бізнесу колишніх спортсменів і військовослужбовців для того, щоб звести ризики, які неодмінно виникають при будь-якому з перерахованих видів, до мінімуму [2].

\section{Список використаних джерел:}

1. Притков В.Ю. \& Жердьов А.Є. (2012). Екстремальний туризм в Україні: сучасний стан та перспектива розвитку. Географія та туризм, (19), 44-52.

2. Олійник В.В. \& Шикіна О.В. (2016). Сучасний стан та перспективи розвитку подієвого туризму в Україні. Глобальні та національні проблеми економіки, (12), 460-463. 


\section{ПОГЛЯД НА УДОСКОНАЛЕННЯ СИСТЕМ УПРАВЛІННЯ ПІДПРИЄМСТВОМ}

Іванов Андрій Васильович

студент III курсу групи БО-17-1

Коледж ракетно-космічного машинобудування

Дніпровського національного університету імені Олеся Гончара

Науковий керівник: Болваненко Людмила Володимирівна

викладач економічних дисциплін

Коледж ракетно-космічного машинобудування

Дніпровського національного університету імені Олеся Гончара

УКРАÏHA

Розвиток підприємництва в умовах ринкової трансформації України має стати одним із важливих чинників соціально-економічного зростання. Проте, як засвідчує аналіз господарської діяльності підприємств, рівень управління підприємництвом та його державна підтримка $\epsilon$ ще недостатнім. Удосконалення організаційної структури підприємства означає насамперед необхідність встановлення оптимальної чисельності та структури управлінського апарату, а також чисельності працівників виробничих відділів та підрозділів згідно з діючими нормами, нормативами та потребами підприємства з урахуванням сучасних ринкових умов господарювання.

Характерною рисою сучасного етапу розвитку економіки $є$ глибокі зміни в усіх її сфрерах, що впливають на систему управління. Управлінську систему підприємства необхідно розглядати як динамічний процес, бо її форми, методи і функції перебувають під впливом багатьох факторів: масштабу підприємства, рівня прибутковості і конкурентоспроможності.

Ефективність діяльності підприємства залежить від багатьох параметрів ступеня розвиненості виробництва, поділу і кооперації праці, використання результатів науково-технічного прогресу, економічних ресурсів, форм стимулювання високопродуктивної праці тощо, але в першу чергу - від ступеня інтегрування зазначених факторів під час іх використання. Справа в тому, що застосування того чи іншого фактора поза зв'язком з іншими ще не забезпечує оптимального економічного розвитку підприємства. Потрібне інтегроване їх використання. Отже, зазначені функції використовуються за допомогою процесу управління підприємством.

Удосконалення системи управління підприємством має відбуватися за такими основними напрямами: удосконалення управління виробничими ресурсами і запасами; підвищення ефективності управління інноваційними процесами на підприємстві, поліпшення якості вироблюваної продукції; удосконалення організаційної структури управління підприємством; оптимізація організації менеджменту через поліпшення системи планування, обліку і контролю за основними показниками діяльності підприємства.

Організація автоматизованої системи збирання і обробки економічної інфрормації також $є$ одним із напрямків удосконалення системи управління, зо 
сприяє побудові раціональної структури апарату управління підприємством i більш ефрективному його використанню для виробничих цілей. [1]

Функціонування зазначеної системи створює умови для підвищення культури управління, а також звільняє керівників і фахівців різних рівнів від ручної праці по збиранню і обробці інформації, скорочує строки прийняття управлінських рішень, поліпшує їх якість.

Удосконалення організаційної структури підприємства означає насамперед необхідність встановлення оптимальної чисельності та структури апарату підприємства, а також чисельності працівників виробничих відділів та підрозділів згідно з діючими нормами, нормативами та реальними потребами підприємства в урахуванням сучасних ринкових вимог. [2]

Одним з напрямків удосконалення системи управління $€$ об'єктивноцільових підхід із закінченим циклом управління при визначенні організаційної структури, нових прав і обов'язків працівників, а також міри відповідальності за свої посадові функції керівників і фахівців різних рівнів.

Цільова об'єктивно-фрункціональна структура апарату управління дозволить компетентно, комплексно, компактно і своєчасно здійснювати процеси управління, як це і потрібно при ринковій економіці. Увесь процес управління тим чи іншим ресурсом розглядається як одне ціле, в рамках якого діють взаємозалежні інформаційні потоки, що проходять через усі функції управління.

Отже, стратегія удосконалення системи управління зосереджується на:

- цілях розвитку і порядку удосконалення комплексної системи управління підприємством і його складовими частинами для забезпечення ефективних рішень і взаємного погодження інформаційних потоків і процесів прийняття рішень, а також організаційних, кадрових і технічних рішень;

- впровадження сучасних засобів і методів керування в межах вибраної комплексної концепції системи керування;

- удосконалення організаційних структур керування підприємством головним чином шляхом використання сучасних гнучких форм (адаптивні, програмно-цільові та інші структури);

- використання засобів автоматизації і обчислювальної техніки для вдосконалення техніко-економічного рівня і якості виробництва;

- використання світового досвіду, а також співпраця всередині країни 3 іноземними партнерами для забезпечення необхідного рівня якості розвитку системи управління на підприємстві.

Система управління демонструє високу ефективність лише тоді, коли менеджери підприємств, які приймають управлінські рішення та встановлюють форми контролю, і працівники, які беруть на себе відповідальність за виконання рішень, діють злагоджено, алей тоді, коли між рівнями управління налагоджений зрозумілий і чіткий алгоритм взаємовідносин. Відсутність такого механізму між рівнями управління знижує управлінську ефективність усієї системи.

\section{Список використаних джерел:}

1. Макаренко М.В. Формування механізму управління ефективним функціонування підприємства (2005). Актуальні проблеми економіки, (1), 126-135. 
2. Абдулін Р. Нові підходи до управління підприємствами в Україні (2009). Підприємництво, господарство і право, (10), 216-218.

\title{
ПРАВОМІРНI IMПОРТНI ОПЕРАЦІЇ НА ТЕРИТОРІЮ УКРАЇНИ БЕЗ ВВЕЗЕННЯ ТОВАРУ
}

\author{
Омельчак Вікторія Дмитрівна \\ здобувач вищої освіти економічного факультету \\ Запорізький національний університет \\ Науковий керівник: Радєва Ольга Георгіївна \\ старший викладач кафедри обліку і оподаткування \\ Запорізький національний університет \\ УKPAÏHA
}

Виходячи з ст.. 1 Закону України від 16.04.1991 р. №959-XII «Про зовнішньоекономічну діяльність» із змінами та доповненнями (імпорт товару) - купівля (оплата в негрошовій формі у тому числі) українським суб'єктом зовнішньоекономічної діяльності в іноземні суб'єкти господарської діяльності товарів з ввезенням або без ввезення товарів на територію України, включаючи купівлю товарів, що призначені установою та організацією України, розташованих за її межею, для власного споживання.

Це говорить про те, що не заборонено здійснення імпортних операцій на територію України чинним законодавством, за зовнішньоекономічними договорами.

Належно до пункту 21 розд. II Положення про заходи захисту та визначення порядку здійснення окремих операцій в іноземній валюті, затвердженого постановою Правління Національного банку України, 365 календарних днів становить граничний строк розрахунку за операціями з експорту та імпорту товарів.

Здійснюється валютний нагляд банком, за дотриманням резидентом граничних строків розрахунків за імпортною операцією резидента, якщо резидентом продукції на дату оплати імпортна операція не завершилась чи в банку немає інформації про завершення імпортної операції без ввезення продукції на територію України. Відповідно до пп. 3 п. 6 Інструкції про порядок валютного нагляду банків за дотриманням резидентами граничних строків розрахунків за операціями з експорту та імпорту товарів, затвердженої постановою Правління НБУ від 02.01.2019 р. №7.

Згідно $з$ пп. 5 п. 9 розд. III Інструкції про порядок валютного нагляду банків за дотриманням резидентами граничних строків розрахунків за операціями 3 експорту та імпорту товарів, затвердженої постановою Правління НБУ від 02.01.2019 р. №7, банк завершує валютний нагляд за дотриманням резидентами граничних строків розрахунків при імпорті продукції без ії ввезення на територію України - після того як було зараховано грошові кошти від нерезидента на поточний рахунок резидента в банку в разі продажу 
нерезиденту продукції в повному обсязі за межами України чи подання документу, що може підтвердити використання резидентом продукції за межами України на підставі контракту або угоди, інших форм документів, що застосовуються в міжнародній практиці та вважаються договором.

Можна зробити висновок, що чинним законодавством України не заборонено здійснювати імпортні операції без ввезення товару на територію за зовнішньоекономічними договорами.

\title{
Список використаних джерел:
}

1. Про затвердження Інструкції про порядок валютного нагляду банків за дотриманням резидентами граничних строків розрахунків за операціями з експорту та імпорту товарів. (Постанова). Вилучено 3 http://sfs.gov.ua/zakonodavstvo/podatkovezakonodavstvo/normativno-pravovi-akti-z-pitan-kpr/postanovi-pravlinnya-nbu/73185.html

2. Про затвердження Положення про заходи захисту та визначення порядку здійснення окремих операцій в іноземній валюті. (Постанова). Вилучено 3 https://zakon.rada.gov.ua/laws/show/v0005500-19

\section{ПРИНЦИПИ РОЗВИТКУ РИНКУ СІМЕЙНОЇ ОСВІТИ}

\author{
Ахновська Інна Олександрівна \\ канд. екон. наук, доцент, доцент кафедри підприємництва, \\ корпоративної та просторової економіки \\ Донецького національного університету імені Василя Стуса
}

УКРÄ̈HA

Сімейна форма здобуття освіти може існувати як паралельно, так і окремо від інших способів організації навчального процесу. Позитивними рисами домашнього навчання $\epsilon$ : вільний режим використання власного часу; можливість відвідувати багато секцій і гуртків одночасно, щоб виявити інтереси дитини; економія грошей на шкільну форму, благодійні внески на ремонт школи тощо; можливість подорожувати; процес, при якому учень вивчає саме те, що йому цікаво; можливість підлаштування під темп дитини; вільний вибір підручників і програм навчання; ця форма ідеально підходить для дітей, які професійно займаються спортом, мистецтвом тощо, а також для тих, чиї батьки переїжджають $з$ місця на місце, і постійна зміна шкіл може бути для дитини стресом. Негативними рисами хоумскулінгу є такі: батькам часто важко організувати навчання дитини вдома та виступати одночасно у ролі як батьків, так і вчителів; дитина повинна мати достатньо високий рівень самомотивації; багато дітей не навчені самостійно робити уроки, а батьки не можуть приділяти навчанню дитини багато свого часу; немає детальної інформації стосовно переходу на домашнє навчання; проблеми 3 соціалізацією дитини в суспільстві; витрати на репетиторів / тьюторів; необхідно обирати і купляти підручники, а також здійснювати оплату навчання дитини у приватних або 
альтернативних школах; хоумскулінг не означає повну свободу і відсутність атестації в традиційній школі.

Слід зазначити, що ця форма навчання практично не розглядається науковцями, хоча нещодавно знайшла відображення у законодавчому просторі нашої країни. Метою тез є визначення основних принципів (тобто, головного, важливого, суттєвого, неодмінного) розвитку ринку сімейної освіти.

Сімейною (домашньою) формою здобуття освіти $€$ спосіб організації освітнього процесу дітей самостійно їхніми батьками для здобуття формальної (дошкільної, повної загальної середньої) та/або неформальної освіти [1]. У Сполучених Штатах Америки, де й відбулося зародження хоумскулінгу, з 56,5 млн учнів на домашньому навчанні знаходиться 2,3 млн, що складає 4,1\%, при чому у динаміці ця цифра зростає [2]. У нашій країні також спостерігається збільшення кількості учнів на сімейній (домашній) формі здобуття освіти.

Дослідження сучасного ринку сімейної освіти дозволяє виділити наступні його характерні принципи: інформаційного дефіциту (недостатність інформації щодо юридичних та організаційних питань); стратегічної спрямованості (цільові показники та терміни реалізації цілей в основному стосуються розкриття потенціалу дитини та виявлення в неї здібностей); системності (навчання відбувається протягом життя, постійно, незважаючи на вихідні чи канікули і розглядається дитиною і батьками вже не як певний процес, а спосіб життя); цілісності (життя - це є навчання, а навчання - це життя); адаптивності (без традиційної школи батьки самостійно піклуються про соціалізацію дитини у суспільстві); гнучкості (зміна темпів, режимів, пристосування до потреб); доступності (багато освітніх центрів і батьків діляться безкоштовними навчальними ресурсами, відкрито освіта); партнерства (батьки об'єднують свої ресурси, створюючі сумісні освітні центри, будуючи разом освітні простори - толока); добровільного залучення та взаємодії (батьки добровільно об'єднують свої ресурси - працю, капітал, час для створення спільних навчальних просторів та взаємодії); паритетності (урахування інтересів усіх сторін); відсутності ієрархічності (навчання будується не на авторитарному авторитеті вчителя, а на дружбі, командній взаємодії, взаємному обміні інформацією та спільному пізнанні); ефективності (при сімейному навчанні програма засвоюється учнем набагато швидше); прозорості (перед батьками не закривають двері навчального простору, навпаки, батьки є бажаними учасниками процесу, оскільки можуть спостерігати за процесом навчання дитини, приймати активну участь, допомагати власній дитині й іншим членам команди тощо); синергії (коли дитина від пасивного користувача освітніх послуг стає активним суб'єктом цього процесу, рівень якості навчання набагато збільшується. У підсумку, обсяг інформації, знань та цікавих здобутків не дорівнює сумі того, що було у вчителя і в учня, а є набагато більшим); автономії (як правило, навчальний процес відбувається автономно від календарного планування, перевірок державних органів тощо, у зручний час для дитини і батьків, відповідно до темпу навчання дитини); гнучкості й адаптивності (при сімейному навчанні освітній процес підлаштовано під здоров'я дитини, настрій, психологічні особливості і може бути змінено і підкореговано); спільного фінансування (часто батьки разом купляють необхідні книжки, канцтовари, матеріали і набори для творчості); інноваційності (батьки активно 
«випробовують» нові методи й методики навчання, інноваційні матеріали); участі місцевої громадськості (при створенні навчальних просторів батьки шукають найкращих фахівців у різних галузях і сфрерах діяльності для розкриття потенціалу власних дітей).

Таким чином, освіта виступає процесом, результатом і системою закладів й установ, спрямованих на соціальну інтеграцію ії̈ суб'єктів, і ключовим на сьогодні є паралельний розвиток основних фрорми здобуття освіти: традиційної та сімейної.

\section{Список використаних джерел:}

1. Про освіту (2017). Закон України. № 2145-VIII. Вилучено з: https://zakon.rada.gov.ua/laws/show/2145-19.

2. Greenwalt, K. (2019) Homeschooling in the United States (2), Retrived from https://www.researchgate.net/publication/331386435_Homeschooling_in_the_United_States. [in English]

\section{ПРІОРИТЕТНІ НАПРЯМИ ГАРМОНІЗАЦІЇ МЕХАНІЗМУ ЦІНОУТВОРЕННЯ НАУКОВИХ ДОСЛІДЖЕНЬ І РОЗРОБОК В КОНТЕКСТІ ЄВРОІНТЕГРАЦІЙНОГО ВЕКТОРУ РОЗВИТКУ УКРАЇНСЬКОÏ НАУКИ}

Коритник Лілія Петрівна канд. екон. наук, старший науковий співробітник відділу бюджетних видатків соціальної сфери та економічного розвитку ДННУ «Академія фрінансового управління» УКРАЇHA

Ключові заходи щодо реформування державної політики у сфері науки і техніки визначають пріоритетом євроінтеграцію української науки та напрями розвитку вітчизняного науково-технічного потенціалу через поступове наближення до європейської політики і права. Так, стратегічні цілі і завдання державної політики з розвитку міжнародного співробітництва в сфері науки і техніки підтверджені Програмою діяльності Уряду від 04.10.2019 р. №188-ІХ [1], зокрема ціль 1.5 передбачає створення умов для інтеграції вчених до європейського та світового дослідницького просторів, а ціль 17.1 передбачає відповідність України критеріям членства в Європейському Союзі, а також впровадження у законодавство України не менше $80 \%$ актів $Є С$, передбачених Угодою про асоціацію між Україною та Європейським Союзом (Глава 9 «Співробітництво у сфері науки і технологій»). Стратегією розвитку сфери інноваційної діяльності на період до 2030 року [2] передбачено збільшення питомої ваги обсягу виконаних наукових і науково-технічних робіт у ВВП країни, збільшення частки реалізованої інноваційної продукції, значне використання об'єктів інтелектуальної власності у реальному секторі економіки. Задля розвитку міжнародного співробітництва в сфері науки і 
техніки та виявлення додаткових можливостей для розвитку національної дослідницької системи України схвалено Дорожню карту інтеграції України до Європейського дослідницького простору (European Research Area - ERA) [3].

Пріоритетність євроінтеграції української науки вимагає адаптації економічної інформації до міжнародних вимог і стандартів та уніфікації методології фінансового забезпечення і нормативно-правового регулювання наукових та науково-технічних програм і проектів з європейськими підходами i принципами.

Одним із головних аспектів формування універсального інформаційного та нормативно-правового простору $€$ гармонізація методичного та організаційного забезпечення провадження наукової та науково-технічної діяльності, імплементація змін і новацій європейського законодавства у нормативно-правове забезпечення бухгалтерського обліку наукових досліджень і розробок, встановлення методологічної єдності з міжнародними принципами ціноутворення наукової (науково-технічної) продукції.

Методологія та технологія ціноутворення, що застосовуються в національній дослідницькій системі, засвідчують невідповідність планування й обліку витрат на виконання наукових досліджень і розробок та калькулювання їхньої собівартості сучасним інфрормаційним запитам та потребам суб'єктів наукової діяльності, вимогам до управління науковою та науково-технічною діяльністю, а також європейським підходам до формування вартості результатів наукових досліджень і розробок.

Наразі для реалізації державної політики щодо активізації вітчизняної наукової діяльності та інтеграції в Європейський дослідницький простір, необхідно гармонізувати підходи до механізмів ціноутворення й переглянути нормативно-правові засади планування, обліку витрат на виконання наукових досліджень і розробок та калькулювання їхньої собівартості:

- ідентифрікувати неузгодженості в нормах вітчизняного та міжнародного законодавства і практики щодо організації та провадження наукової та науково-технічної діяльності для імплементації міжнародної науково-технічної політики в національну дослідницьку систему;

- дослідити кращий світовий досвід та здійснити наукове обґрунтування технології формування структури та складу витрат на вироблення науковотехнічної продукції для удосконалення національної практики систематизації інформації відповідно до міжнародних стандартів та організації ефективної системи управління витратами;

- визначити особливості формування стадій та етапів технологічного процесу виконання наукових досліджень і розробок, дослідити їх взаємозв'язок з методологію і організацію обліку наукового та (або) науково-технічного (прикладного) результату;

- розробити пропозиції щодо гармонізації європейських і вітчизняних методологічних та організаційних засад ведення обліку витрат на наукові досліджень і розробки для їх імплементації в нормативно-правове забезпечення бюджетного процесу та бухгалтерського обліку в державному секторі України;

- сформувати концептуальні засади генерування нематеріальних активів, що стали результатом виконання наукових досліджень і розробок та 
забезпечити уніфікацію технології обліку витрат на їх проведення відповідно до НП(С)БОДС, П(С)БО, IPSAS та GAAP USA задля обґрунтування оцінки та ефективного використання інтелектуальної власності і створення вітчизняного ринку наукової і науково-технічної продукції;

- систематизувати та оптимізувати методи обліку витрат і калькулювання собівартості, що притаманні теорії обліку та вітчизняній і міжнародній практиці для визначення та обґрунтування вибору сучасних прогресивних методів 3 урахуванням специфіки діяльності суб'єктів наукової і науково-технічної діяльності та інформаційних потреб управління;

- дослідити методологічні підходи та теоретико-методичні засади організації та реалізації сучасного економічно аргументованого механізму калькулювання собівартості наукових досліджень і розробок в контексті 3 міжнародними принципами ціноутворення наукової (науково-технічної) продукції;

- розробити пропозиції щодо модернізації форм звітності в контексті інтерпретації інфрормації про витрати і показник собівартості як ключових елементів, що характеризують фрінансові результати діяльності суб'єктів наукової діяльності та виконання відповідних бюджетних програм;

- забезпечити наукове обґрунтування напрямів удосконалення організаційно-методологічного та нормативно-правового провадження наукової та науково-технічної діяльності та вироблення методичного забезпечення з обліку витрат і калькулювання собівартості наукових досліджень і розробок з метою уніфікації підходів до механізму ціноутворення науково-технічної продукції та обґрунтування обсягів бюджетного фінансування.

Висновки. Формування універсальних засад методології та методики ціноутворення наукових досліджень і розробок сприятиме ефективному та раціональному управлінню ресурсами суб'єктів сфери науки і техніки; забезпечить визначення обґрунтованих обсягів фрінансування наукової та науково-технічної діяльності, окремих програм і проектів; сприятиме наближенню нормативно-правового забезпечення бюджетного процесу та бухгалтерського обліку в державному секторі України до Європейського дослідницького простору.

\section{Список використаних джерел:}

1. Верховна Рада України. (2019). Про Програму діяльності Кабінету Міністрів України (Постанова № 188-IX, 4 жовтня). Вилучено 3 https://zakon.rada.gov.ua/laws/show/188-ix

2. Кабінет Міністрів України. (2019). Про схвалення Стратегії розвитку ссфери інноваційної діяльності на період до 2030 року (Розпорядження № 526-p, 10 липня). Вилучено 3 https://zakon.rada.gov.ua/laws/show/526-2019-\%D1\%80

3. Міністерство освіти і науки України. (2018). Дорожня карта інтеграції України до Європейського дослідницького простору (ERA-UA) (Рішення колегії № 3/1-7, 22 березня). Вилучено 3 https://mon.gov.ua/storage/app/media/kolegiya-ministerstva/2018/05/1-dorozhnyakarta-integratsii-ukraini-do-evro.pdf 


\title{
ПРОБЛЕМИ БЕЗПЕКИ В ГОТЕЛЯХ
}

\author{
Кушнір Олена Олегівна \\ Вінницький торговельно-економічний інститут КНТЕУ
}

Науковий керівник: Малюта К. Г.

Вінницький торговельно-економічний інститут КНТЕУ

УКРАÏHA

У нестабільному розвитку країни, безпека будь-якого об'єкту виходить на перше місце, так як останнім часом відбувається все більше зростання злочинності та збільшення кримінальної обстановки.

У злочинному світі не залишаються без уваги готелі, які мають розширення дрібних і висококласних готельних комплексів. Створення системи безпеки, буде повністю гарантувати гостям готелю спокій і свою безпеку, а також мати імідж висококваліфрікованого комплексу.

Важливим завданням готельного бізнесу $\epsilon$ цілковите забезпечення надійної безпеки клієнтів і персоналу. Не кожен готель може дозволити підтримувати надійну та всебічну систему безпеки, тому що останнім часом власники змушені зменшувати свій бюджет, для підтримки готельної послуги, так як їх доходи стрімко зменшились приблизно в 3 рази.

Відносно інших об'єктів видів діяльності, готель має певні відмінності, такі як [1]:

- готель $є$ таким об'єктом, що передбачає створення іміджу та комфортних умов для гостей, при цьому не привертаючи уваги, до вбудованих пристроїв безпеки в будинку;

- готель в основному розташований у місті та приміській зоні, маючи при цьому розвинуту мережу транспортного сполучення, а також знаходиться у центрі міста;

- порядок проходу в готелі та номерах не має створювати великих труднощів для гостя та мати простий вигляд;

- у готелі може бути присутня велика кількість людей, яка належить до різних соціальних груп;

- готель є об'єктом в якому може бути присутня велика кількість людей, які належать до різних соціальних груп;

- кількість та склад присутніх в готелі гостей мають значну динаміку у часі.

Реалізація умов, при яких би клієнти готелю і його співробітники почували $б$ себе спокійно, впевнено і комфортно, $є$ головним завданням розробки концепції безпеки.

Безпека має в собі не лише захист від кримінальних посягань, а і створення заходів забезпечення захисту від пожежі, вибухів та інших надзвичайних подій. Вирішення цих проблем вимагає системного підходу, створеного на аналізі роботи об'єкта, виявлення слабких зон і небезпечних загроз, складання всіх можливих сценаріїв кримінальних дій і виробленні адекватних заходів протидії.

Комплексний підхід забезпечує повне поєднання організаційних, фрізичних і технічних заходів попередження i швидкого реагування на будь-яку 
небезпечну ситуацію. Ключовим $є$ правильний вибір системи безпеки, технічних засобів, точне проектування, обслуговування і монтаж.

Небезпечними ситуаціями і загрозами у діяльності готелів $є$ [2]:

- саме найперше - це пожежа, причиною якої $€$ несправність електрообладнання, недбалість гостей, порушення або недотримання правил безпеки персоналом, навмисний підпал;

- вибух, що викликаний установкою вибухівки у кримінальних цілях, або вибух газу при його витоку (у місцях приготування їжі при використанні газового обладнання);

- незаконна крадіжка цінностей, документів, установки вибухових пристроїв або підслуховуючої апаратури у відсутність гостей в номері сторонніми особами;

- незаконний прохід у номери обслуговуючого персоналу з тими ж кримінальними цілями, обумовлений кримінальними мотивами або шантажем злочинців;

- напад на гостя у номері, ліфті або в іншому місці готелю;

- напад на касу у робочий час або спроба ії відкриття у неробочий час;

- напад на адміністрацію готелю з метою шантажу, вимоги відкрити касу або нейтралізувати систему безпеки;

- терористичний акт із взяттям заручників клієнтів готелю або спроба підриву або підпалу;

- збройний напад на номери, орендовані у готелів комерційними фрірмами під офріси.

Прикладом для роз'яснення, слугує курортне місто Затока, де в одному із готелів стався вибух, у результаті чого постраждала одна людина. Попередня причина - вибух газо-повітряної суміші при підготовці до підпалу. Для того, щоб більше не повторювалось подібних ситуацій, потрібно визначити основні напрямками по забезпеченню безпеки сучасних готелів, такі як:

- повний контроль охорони по периметру готелю;

- швидке реагування до правоохоронних органів про замінування будівлі;

- цілковитий контроль в готелі (електронна карткова бездротова он-лайн система, функція відео ідентифікації);

- комплекс заходів для протипожежного захисту (ефективне і своєчасне виявлення загоряння 3 точною вказівкою місця, автоматичне оповіщення служби безпеки, усіх співробітників і гостей готелю, організація евакуації людей з будинку, що горить, включаючи розблокування всіх дверей і ліфтів);

- охоронна сигналізація і відео спостереження (датчики руху чужих людей, відеоспостереження за порядком) [3, с. 24-25].

Таким чином, створення надійної системи безпеки готелів $€$ однією із найголовніших завдань в умовах розвитку бізнесу. Для того, щоб реалізувати заходи, які спрямовані на забезпечення достатнього рівня безпеки готелів в Україні, слід врахувати фрінансову можливість готелів, їх риси, умови функціонування, кваліфікацію персоналу та технічне оснащення готелів.

\section{Список використаних джерел:}

1. Іванов, І. В., Панюков, Д.В.Концепція забезпечення безпеки сучасного готелю. Вилучено з http://www.sec4all.net/hotel-secur.html. 
$116 \bullet$ Problèmes et perspectives d'introduction de la recherche scientifique innovante $\bullet$ Volume 1

2. Єрмошенко, М. М. (2015). Фінансова складова економічної безпеки : держава i підприємництво. Київ.

3. Виноградська, А. (2016). Стратегія готельного бізнесу в Україні. Діловий вісник, (11), 2425.

\section{ПРОБЛЕМИ ЗБАЛАНСОВАНОСТІ ПЛАТІЖНОГО БАЛАНСУ УКРАЇНИ}

Джанумова Лідія Тахірівна

студентка економічного фракультету

Придніпровська державна академія будівництва та архітектури

Оскома Олена Володимирівна

кандидат економічних наук, доцент кафедри фінансів, обліку і маркетингу

Придніпровська державна академія будівництва та архітектури

УКРӒ̈HA

В умовах глобалізації світового господарства значну роль у розвитку економіки країни відіграють її зовнішньоекономічні зв'язки. Широкий спектр міжнародних відносин країни відображається в балансовому рахунку ії міжнародних операцій, який називається платіжним балансом. Платіжний баланс складається у формі бухгалтерських рахунків, що містять статистичну інформацію із зовнішньоторговельних операцій господарських суб'єктів країни і закордону за певний період.

Дефріцит зведеного платіжного балансу України в травні 2019 року склав $\$ 0,8$ млрд. Через дефіцит платіжного балансу і виплат кредитів МВФ міжнародні резерви України знизилися до \$ 19,4 млрд станом на кінець травня 2019 року або 3,2 місяця імпорту майбутнього періоду.

У травні поточний рахунок зведений з профріцитом (\$ 0,2 млрд) у порівнянні 3 майже нульовим сальдо в квітні 2019 і травні 2018 роках. Цьому сприяло як звуження десріциту торгівлі товарами, так і розширення профіциту первинних доходів [1].

Як вказують в Нацбанку, обсяги експорту українських товарів у вересні 2019 року скоротилися на 3,6\% - до 3,3 млрд доларів. В цілому за січень-вересень експорт товарів зріс на 9,9\% - до 31,5 млрд доларів. У той же час імпорт товарів у вересні склав 5,1 млрд доларів, його річні темпи зростання залишалися високими $(17,3 \%)$ на тлі стійкого внутрішнього попиту і високих цін на енергоносії. В цілому за січень-вересень в порівнянні з аналогічним періодом минулого року, імпорт товарів зріс на 15,6\% - до 40,6 млрд доларів [2].

У той же час чистий приплив капіталу за фінансовим рахунком у вересні 2019 року склав 1,1 млрд доларів (у вересні минулого року - 1,3 млрд доларів) і був забезпечений операціями приватного сектора насамперед за торговими кредитами. Чистий приплив прямих іноземних інвестицій склав 102 млн доларів, 93\% якого було направлено в реальний сектор в формі акціонерного капіталу. За січень-вересень цього року чистий приплив прямих іноземних інвестицій оцінений в 1,5 млрд доларів [3]. 
В цілому за січень-вересень 2018 року чистий приплив коштів по фрінансовому рахунку сформувався на рівні аналогічного періоду 2017 року i склав 3,4 млрд доларів. У травні відновилося зростання фрізичних обсягів експорту чорних металів завдяки нарощуванню металургійного виробництва. Однак вартісні обсяги експорту цієї групи залишалися менше торішніх через більш низьких цін на металургійну продукцію.

Істотно збільшилися поставки залізних руд (в 1,6 рази г / г), чому серед іншого сприяли найвищі за останні шість років світові ціни. Зростання імпорту товарів в травні сповільнилося до 8\% г / г з 12,8\% в квітні насамперед через енергоносії. Після значних закупівель нафтопродуктів в квітні, викликаного більш раннім стартом посівної кампанії, в травні їх вартісні обсяги залишилися на рівні попереднього року [4].

Сповільнилося зростання вартісних обсягів імпорту природного газу, зокрема через зниження цін на європейському ринку і ефректу бази порівняння внаслідок певного зміщення графріка закачування газу в підземні сховища. Річні темпи зростання імпорту хімічної продукції знизилися до 8\% г / г), що серед іншого зумовлено значними закупівлями хімічними підприємствами окремих видів пластмас у травні 2018 року.

Зростання імпорту продукції машинобудування прискорився насамперед через істотне нарощування закупівель електрообладнання для будівництва об'єктів альтернативної енергетики. Крім того, високими темпами продовжував зростати імпорт легкових автомобілів, в тому числі в результаті розмитнення раніше ввезених автомобілів 3 іноземною реєстрацією, враховуючи законодавчі зміни, якими відклали застосування штрафів за перевищення терміну їх перебування в Україні.

За фінансовим рахунком на відміну від попередніх періодів спостерігався значний відтік капіталу - \$1 млрд. Це було обумовлено плановим погашенням суверенних єврооблігацій, що лише частково було компенсовано подальшим нарощуванням інвестицій нерезидентів в гривневі ОВДП. У приватному секторі також сформувався чистий відтік капіталу: збільшення готівки поза банками перевищила надходження боргового та інвестиційного капіталу в реальний сектор і приплив капіталу в банківський сектор [5].

Висновки. Однією остаточною альтернативою врівноваження платіжного балансу є:

1) використання країною своїх офріційних золотовалютних резервів. Іноді Центральний банк країни може продавати частину своїх резервів та купувати на них національну валюту з метою підтримки її обмінного курсу. Таке використання резервів утворює статтю кредиту, оскільки резерви ніби надходять на баланс, одночасно залишаючи рахунок резервів. Отже, резерви можуть використовуватися для покриття дефіциту з будь-якої позиції платіжного балансу. І навпаки, якщо з тієї чи іншої статті платіжного балансу утворюється додатне сальдо, то отримані кошти можна застосувати для формування резервів.

2) усунення змін у внутрішній економіці. Одним із основних джерел дефіциту платіжного балансу є інфляція (переповнювання каналів обертання грошової маси понад потреби товарообігу, що викликає знецінення грошової одиниці і ріст цін). Темпи її можна зменшити жорсткою грошовою та фінансовою політикою, високими відсотковими ставками, контролем за зарплатою та цінами. Але цей шлях призводить до економічного застою та безробіття. Можна також урізноманітнити експорт за допомогою 
118 - Problèmes et perspectives d'introduction de la recherche scientifique innovante $\bullet$ Volume 1

індустріалізації та перерозподілу ресурсів на продукцію, що конкурентоспроможна на світовому ринку. Можна сприяти виробництву продукції, здатної конкурувати з імпортною, якщо це економічно виправдано.

3) можливість зміни валютного курсу для відновлення рівноваги у платіжному балансі. Багато країн розцінюють саме платіжний баланс як ключовий чинник прийняття рішення про доцільність чи необхідність зміни курсу їх валюти, роблять вітчизняну продукцію дешевшою на міжнародних ринках, розширюючи тим самим експорт. Одночасно девальвація робить дорожчими імпортні товари, а це призводить до зниження попиту і отже, - до скорочення імпорту.

\section{Список використаних джерел:}

1. Intercfax - Україна. Інфоормаційне агенство. (2019). Вилучено 3 https://ua.interfax.com.ua/news/economic/604944.html

2. Економічна правда. (2018). Вилучено з https://www.epravda.com.ua/news/2018/10/31/642191/

3. Мінфін. (2018). Вилучено 3 https://minfin.com.ua/ua/2018/10/31/35465328/.

4. Макроекономічний та монетарний огляд. (2019). Вилучено 3 https://bank.gov.ua/doccatalog/document?id=97873792

5. Платіжний баланс України. (2019). Вилучено 3 https://mind.ua/news/20199168-platizhnijbalans-ukrayini-v-travni-bulo-zvedeno-z-deficitom-u-750-mln

\section{РЕСУРСНИЙ ПОТЕНЦІАЛ ПІДПРИЕМСТВА}

Говорун Віталій Вікторович здобувач вищої освіти факультету економіки, менеджменту та права Вінницький торговельно-економічний інститут КНТЕУ

Науковий керівник: Богацька Наталія Миколаївна канд. екон. наук, доцент кафедри економіки та міжнародних відносин Вінницький торговельно-економічний інститут КНТЕУ УКРАÏHA

Усвідомлення важливості розвитку підприємства як умови його існування дає змогу визначити необхідність дослідження джерел розвитку. Зокрема йдеться про ресурсний потенціал підприємства, тобто перспектива майбутнього стану підприємства, якого можливо досягти лише в результаті розвитку. Ігноруючи той факт, що навіть за допомогою примітивного причиннонаслідкового зв'язку твердження про вплив потенціалу підприємства на його розвиток $€$ безсумнівним, детальне розкриття цього питання вимагає значної уваги та особливої оцінки.

Проблемні питання щодо визначення сутності ресурсного потенціалу підприємства, ефективного його використання та управління на рівні підприємства висвітлені у працях зарубіжних і вітчизняних науковців, зокрема: Бачевської Б. Є., Богацька Н.М., Вовка Ю. Я., Заблодської І. В., Краснокутської 
Н. С., Олексюка О. І., Решетняка О. О., Рєпіної І. М., Федоніна О. С., Чухрай Н. І., Яремка І. Й.

Ресурси - це сукупність матеріальних і нематеріальних елементів, які прямо чи опосередковано беруть участь у виробничому процесі. В свою чергу, вивчення ресурсного потенціалу підприємства $€$ необхідною складовою та передумовою формування стратегії (стратегічних альтернатив) його розвитку. Коло визначень ресурсного потенціалу підприємства дуже широке - від надзвичайно вузького його розуміння як річного обсягу виробництва продукції до таких загальних категорій, як соціально-економічна система [1, с. 56]. Иого вивчали як елемент виробничих відносин щодо використання здатності трудових ресурсів до створення матеріальних благ, як сукупність наявних ресурсів для досягнення поставленої мети, як максимально можливий обсяг матеріальних благ і послуг, який можна отримати за умови оптимального використання наявних ресурсів, як реальну чи ймовірну здатність виконати цілеспрямовану роботу та ін.

Наявність ресурсного потенціалу на підприємстві ще не свідчить про саму діяльність підприємства. Тільки сполучення всіх складових ресурсного потенціалу воєдино, а саме - поєднання засобів виробництва і праці за умов використання певних технологічних процесів утворює виробничий потенціал підприємства [2].

Управління ресурсним потенціалом підприємства - це безперервний, динамічний, цілеспрямований процес, який полягає у впливі суб'єкта управління ресурсним потенціалом на об'єкт на основі застосування функцій, принципів, методів і процедур управлінського характеру, з метою досягнення ефективнішого залучення, використання та розвитку ресурсного потенціалу підприємства [3].

Ресурсний потенціал підприємства - це сукупність ресурсів, які $є$ у його розпорядженні або можуть бути залучені до його господарської діяльності для створення товарів, виконання робіт чи надання послуг з метою максимального задоволення потреб споживачів та підвищення конкурентоспроможності підприємства на ринку. Структура ресурсного потенціалу підприємства містить такі складові: потенціал матеріальних ресурсів, трудовий потенціал та потенціал основних фондів (три складники виробничого потенціалу), а також фрінансовий та інформаційний потенціал [4].

На нашу думку, це найбільш прийнятна структуризація, яка уникає проблеми дублювання сутності та функцій тієї чи іншої складової ресурсного потенціалу.

Основними складниками потенціалу є: організаційно-управлінський, кадровий, інтелектуальний, фрінансовий, технологічний, інформаційний, ринковий, інтерфейсний та науково-дослідний. Усі ці види потенціалу характеризують ресурси підприємства та можливість їх застосування для інноваційного розвитку.

Таким чином, ресурсний потенціал - це можливості ресурсів, які можуть бути активізовані у процесі операційної діяльності підприємства. Суб'єктна складова ресурсного потенціалу підприємства характеризується інтелектуальними та морально-етичними якостями персоналу, знаннями, досвідом, традиціями. Ресурсний потенціал підприємства включає всі види 
ресурсів, наявні на підприємстві. Сутність ресурсного потенціалу підприємства визначають поточні та перспективні можливості підприємства, які характеризуються перетвореннями ресурсів завдяки свідомій діяльності осіб для формування необхідного продукту.

\section{Список використаних джерел:}

1. Краснокутська, Н. С. (2015). Потенціал підприємства: формування та оцінка. Київ: Центр навчальної літератури.

2. Алєксєєв, С. Б. (2018) Визначення поняття «ресурсний потенціал підприємства». Держава та регіони. (2), 53-56.

3. Богацька, Н. (2010). Ресурсне забезпечення діяльності підприємства в сучасних умовах господарювання. Вилучено $3 \mathrm{http} / /$ intkonf.org/ken-dotsbogatska-nm-shvetsoiresursnezabezpechennya-diyalnosti-pidpriemstva-v-suchasnih-umovahgospodaryuvannya

4. Шаманська, О.І. (2019) Система ефективного управління ресурсним потенціалом підприємства. Ефрективна економіка. Вилучено з http://www.economy.nayka.com.ua

\section{РОЛЬ МАРКЕТИНГОВОЇ ІНФОРМАЦІЇ У РОЗВИТКУ ВІТЧИЗНЯНОГО ПІДПРИЄМСТВА}

\section{Олійник Володимир Михайлович}

здобувач вищої освіти Інституту економіки і менеджменту Національний університет «Львівська політехніка»

Науковий керівник: Лихолат Світлана Михайлівна канд. екон. наук, доцент, доцент кафедри маркетингу і логістики Національний університет «Львівська політехніка»

УКРАÏHA

Загальна система управління сучасним вітчизняним підприємством передбачає розвиток процесів управління персоналом, фінансового управління, організаційного управління, виробничого управління, управління інноваціями, логістичного управління та управління маркетингом [1].

Зокрема, управління маркетингом полягає у формуванні ланцюга який починається В момент проведення маркетингових досліджень та завершується реалізацією стратегічних програм. Водночас, управління маркетингом передбачає ринкову орієнтацію підприємства, базується на стратегічних підходах й націлене на формування довготривалого комерційного результату який враховує ситуаційне управління, адаптацію до умов зовнішнього середовища, можливостей завоювання конкурентних позицій та переваг, розробляє стратегію активного впливу на споживачів [1].

Маркетингове управління забезпечується, як правило, завдяки зовнішнім інформаційним потокам які пов'язані із ситуаційним аналізом зовнішнього середовища і коректуванням інших управлінських функцій із застосуванням зовнішніх інформаційних потоків, які враховують маркетингові плани та наявні маркетингові результати, які $€$ похідною від параметрів девіації фракторів 
маркетингового зовнішнього середовища яке є динамічним та розглядається за певними критеріями: вплив зовнішнього середовища та виникнення нових можливостей й загроз; вплив зовнішніх факторів на формування бізнес-моделі й маркетингову стратегію; інтенсивність впливу зовнішнього середовища [2].

В процесі маркетингового управління отримується маркетингова інформація, яка являє собою сукупність знань, відомостей та повідомлень про наявне зовнішнє та внутрішнє середовище функціонування підприємства, які генеруються та передаються керівниками для прийняття відповідних управлінських рішень з метою реалізації сформованих маркетингових завдань та досягнення маркетингових цілей. Отриманий масив інформації використовується як маркетологами, так і іншими працівниками (фінансистами, логістами, менеджерами і ін.) в залежності від виробничих потреб. Тобто, на підприємстві реалізується стратегічне маркетингове управління, яке враховує як внутрішні так і зовнішні зв'язки, які постійно коригуються та адаптуються під певні виробничі потреби та фінансується за обраними напрямами із врахуванням наявного персоналу та рівня його кваліфікації й досвіду. Не менш важливим є рівень інноваційних процесів, який потребує постійного аналізу новітніх технологій, а також доцільність їх використання в діяльності окремо взятого підприємства [2, 3].

Маркетингова інформація наділена певними особливостями, які потрібно враховувати у процесі її планування та отримання, а також аналізі й просуванні, а саме: мінливість інформації, яка ускладнює процес ії формалізації та відбору; різна природа інформаційних даних (кількість, якість, візуалізація і т.п.) [3]. Така ситуація вимагає використання певних маркетингових інструментів для опрацювання отриманої інформації. До прикладу, отримання великого масиву інформації ускладнює її структурування та ускладнює процес її використання й отримання достовірних даних внаслідок чого виникає потреба у забезпеченні ефективної диференціації при розподілі інформації.

Отже, маркетингова інформація сприяє створенню конкурентних переваг та зміцненню ринкових позицій того вітчизняного підприємства, яке організовує не лише збір маркетингової інформації але й вміло її систематизує, налагоджує інформаційні канали, враховує можливості сучасних інформаційних технологій, створює відповідні моделі аналізу.

\section{Список використаних джерел:}

1. Шелюк, Л. О., Крикавський, Є. В., Дейнега, І. О., Дейнега, О. В. \& Патора, Р. (2008). Маркетингова інформація. Рівне: Олег Зень.

2. Яневич, М. М. (20111). Удосконалення прийняття стратегічних управлінських рішень на основі маркетингової інформаційної системи. Українська наука: минуле, сучасне, майбутнє, (16), 322-329.

3. Єжова, Л. Ф. (2002). Інформаційний маркетинг. Київ: КНЕУ. 


\section{РОЛЬ ПОДАТКОВИХ НАДХОДЖЕНЬ У ФОРМУВАННІ ДОХІДНОЇ ЧАСТИНИ БЮДЖЕТУ}

Іванова Вікторія Сергіївна

здобувач вищої освіти економічного фракультету

Запорізький національний університет

Науковий керівник: Саєнко Олена Романівна

канд. екон. наук, доцент кафедри економіки

Запорізький національний університет

УКРАÏHA

Значну роль у фрормуванні дохідної частини бюджету України належить податкам, які займають майже 79 \% всіх надходжень. Вони $є$ необхідною умовою виконання функцій і завдань, що покладені як на органи державної влади, так і на органи місцевого самоврядування. За рахунок видатків бюджету фінансуються програми освіти, охорони здоров'я та соціальної сфери. Основним джерелом поповнення яких виступають податкові надходження, які включають в себе загальнодержавні та місцеві податки і збори.

Державний бюджет України $є$ показником рівня економічного розвитку країни, завдяки правильному здійсненню бюджетного процесу забезпечується економічна та соціальна стабільність держави, а також зростає життєвий рівень населення. Органи державної виконавчої влади здійснюють державне регулювання, стимулювання економіки, фінансуються соціальні напрями. Податки $€$ основним джерелом наповнення Державного бюджету України, виконуючи функції економічну та фріскальну.

Згідно Бюджетного Кодексу України [1], податковими надходженнями визнаються встановлені законами України про оподаткування загальнодержавні податки і збори (обов'язкові платежі) та місцеві податки і збори (обов'язкові платежі).

Відповідно до класифікації податкові надходження поділяються на прямі і непрямі. В основу якої покладено передусім вид об'єкта оподаткування та характер взаємовідносин між платниками податків і державними фріскальними органами. Прямі податки встановлюються безпосередньо щодо платників і сплачуються за рахунок їх доходів і майна. Розмір яких обумовлюється майновим станом платників. До прямих податків належать: податок на прибуток підприємств; податок з доходів фізичних осіб (ПДФО); рентна плата; податок на майно тощо. Непрямі податки встановлюються в цінах товарів і послуг, розмір яких для окремого платника визначається величиною споживання і не залежить від його доходів [2]. До них належить: податок на додану вартість (ПДВ), акцизний податок і мито.

Найбільшу питому вагу в загальній сумі надходжень до державного бюджету у 2017 році складають надходження з податку на додану вартість із ввезених на територію України товарів (250 530,2 млн. грн або 31,58 \%); податку на доходи фізичних осіб (75 033,4 млн. грн або 9,46 \%); податку на прибуток підприємств (66 911,9 млн. грн або 8,44 \%) [3].

У формуванні дохідної частини бюджету найбільша частка належить 
непрямим податкам, а саме: податку на додану вартість, акцизному податку та миту, це $\epsilon$ негативним явищем, адже в умовах кризового стану країни, спричиняє посиленню фіскальної функції податків, що в свою чергу веде до зростання податкового навантаження на споживання.

Основними факторами впливу на обсяг податкових надходжень є макроекономічні чинники, які зазнають змін кожного року, до них належить: розмір ВВП, законодавчо-нормативна база, структура платіжного балансу. На обсяг надходжень також мають вплив мікроекономічні чинники: вибір підприємством свого виду оподаткування, наявність податкових пільг; розмір прибутку та валового доходу, що отримує підприємство, витрати на оплату праці тощо.

Основними недоліками сучасної податкової системи України є: недосконалість і нестабільність законодавства; витрати на адміністрування податкової системи є незначними; податки виступають не інструментом підвищення конкурентоспроможності країни, а має виключно фіскальний характер, регулююча функція не зорієнтована на сталий розвиток та підвищення конкурентоспроможності податкової системи країни; відтік капіталів закордон, подвійне оподаткування, а також ухилення від сплати податків. Все це веде до погіршення.

Для усунення недоліків, з 01.01.2017 набув чинності закон щодо покращення інвестиційного клімату в Україні [4], згідно якого передбачається: ліквідація податкової міліції та створення нового органу - Фінансової поліції, діяльність якого регламентуватиметься окремим Законом; адміністрування всіх баз даних Мінфіном або держпідприємством при Мінфіні; запровадження повноцінного електронного кабінету платника податків; ведення відкритого реєстру заяв про розстрочення та відстрочення грошових зобов'язань або податкового боргу на сайті Державної фіскальної служби.

Отже, податки займають головну роль у забезпеченні виконання державою своїх функції. Вони є основною бюджетоутворюючою ланкою, їм належить близько $80 \%$ надходжень. Проте існує ряд недоліків, що заважають ефективному розвитку держави. На нашу думку, слід привести законодавчонормативну базу у сфері справляння податків до стану, що сприятиме економічному зростанню країни; забезпечити умови, що не будуть сприяти ухиленню від сплати податків та усунення тіньового бізнесу.

\section{Список використаних джерел:}

1. Бюджетний кодекс України № 2456-VI. (2010). Вилучено з http://zakon.rada.gov.ua/.

2. Зварич, О.В.Податкові надходження: методологія прогнозування. Київ: КНТЕУ.

3. Державна казначейська служба України. Вилучено з http://www.treasury.gov.ua/.

4. Про внесення змін до Податкового кодексу України щодо покращення інвестиційного клімату в Україні (Закон України), № 1797-19. (2016). Вилучено 3 http://zakon2.rada.gov.ua/laws/show/1797-19/page. 


\section{СТРАТЕГІЧНЕ ПЛАНУВАННЯ ЕКОНОМІЧНОЇ АКТИВНОСТІ ПІДПРИЄМСТВ ТОРГІВЛІ}

Кащена Наталія Борисівна

канд. екон. наук, доцент, професор кафедри фрінансів, аналізу та страхування Харківський державний університет харчування та торгівлі

УКРАЇНА

Активізація процесів глобалізації та інтеграції за високої непередбачуваності змін законодавчого регулювання, очікувань споживачів, форматів ведення бізнесу та рівня конкуренції істотно змінює бізнес-оточення підприємств торгівлі. Це примушує керівників і власників бізнесу до пошуку адекватних способів набуття та зміцнення конкурентних переваг, підвищення іміджу та створення умов для сталого розвитку. За мінливості бізнес-оточення та уподобань споживачів дедалі більшої вагомості набуває проблематика стратегічного планування економічної активності торговельного підприємства.

Планування напрямів реалізації стратегічних змін $\epsilon$ важливою функціонально-структурною складовою стратегічного управління, орієнтованою на розробку планів, програм і проектів переходу економічної активності торговельного підприємства 3 поточного до цільового ії рівня. Забезпечити ефективність стратегічного планування економічної активності підприємств торгівлі дозволяє запропонована у [1] концептуальна ієрархічна модель стратегічного планування економічної активності підприємства торгівлі (рис. 1). В основу її розробки було покладено адаптовану до визначеної проблематики багаторівневу модель формалізації державної політики та управління в сфрері забезпечення національної безпеки [2], методику стратегічного планування [3] та технологію методу аналізу ієрархій [4; 5], імплементація основних положень яких пов'язана із визначенням головного критерію досягнення мети стратегічного планування, обґрунтуванням рівнів ієрархії та складу елементів на кожному з них, встановлення та уточнення горизонтальних та вертикальних взаємозв'язків між елементами різних рівнів iєрархії.

За такого підходу забезпечується:

- ефективність розв'язання багатокритеріальної задачі забезпечення економічної активності підприємства в умовах динамічних змін бізнесоточення та уподобань споживачів;

- можливість максимального використання всієї доступної інфрормації та знань, особистого досвіду і уявлення, здатних зменшити негативні наслідки неповноти та невизначеності її вихідних параметрів;

- оцінювання рівня економічної активності підприємства за відсутності єдиного масштабу шкал та наявності цифрових шкал;

- застосовування порівняно простих правил аналізу складних систем, що ґрунтуються на можливості кількісного оцінювання головного критерію (забезпечення економічної активності підприємства), та враховує вплив кожного з елементів моделі на кожному з її рівнів на кінцевий результат. 


\begin{tabular}{|l|l|}
\hline $\begin{array}{l}\text { Формування головної мети стратегічного планування економічної } \\
\text { активнсті торговельного підприсмства }\end{array}$ \\
\hline $\begin{array}{l}\text { формалізація процесу прийняття управлінських рішень в сфері забезпечення } \\
\text { економічної активності підприємства шляхом розробки сукупнсті } \\
\text { взасмопов'язаних стратегічних документів (концепція, стратегія, програма, } \\
\text { план, заходи, бюджет), які санкціонують реалізацію сценарію переведення } \\
\text { (утримання) ситуації з поточного до цільового ії рівня, що відповідає концепції } \\
\text { сталого розвитку підприємства і його можливостям щодо ресурсного } \\
\text { забезпечення й адекватної реакції на зміни бізнессередовища та потреб } \\
\text { стейкхолдерів у середньо- та довгостроковій перспективі }\end{array}$ \\
\hline
\end{tabular}

\begin{tabular}{|c|c|c|c|c|c|c|}
\hline \multirow[b]{2}{*}{ 二悉 } & \multicolumn{6}{|c|}{$\begin{array}{l}\text { Декомпозиція економічної активності підприємства і представлення ї̈ у } \\
\text { вигляді сукупності визначальних елементів та форм її прояву }\end{array}$} \\
\hline & & & Ка & акти & акт & та інг \\
\hline
\end{tabular}
Е можливості та загрози) економічної активності підприємства у розрізі їі складових
乙总 Формування концепції економічної активності підприємства торгівлі (в цілому і за окремими композиційними елементами)

Розробка стратегій економічної активності торговельного підприємства (в цілому і за окремими композиційними елементами)

Розробка програм економічної активності підтрисмства торгівлі (в цілому і за окремими композиційними елементами)

Розробка планів економічної активності торговельного підприємства (в цілому і за окремими композиційними елементами)

Розробка заходів $i$ дій із забезпечення економічної активності підшрисмства торгівлі (в цілому i за окремими композиційними елементами)

Формування бюджетних програм, що спрямовані на забезпечення економічної активності підриємства торгівлі (в цілому і за окремими елементами)

Рис 1. Концептуальна ієрархічна модель стратегічного планування економічної активності підприємства в умовах динамічних змін бізнессередовища та потреб стейкхолдерів

На відміну від існуючих представлена концептуальна модель враховує особливості стратегічного планування, що пов'язані із функціонуванням системи забезпечення економічної активності торговельного підприємства в різних режимах, обмеженістю її ресурсів, доступністю і якістю інформації бізнес-середовища, комплексністю, множинністю і паралельністю характеру 
впливів внутрішніх і зовнішніх чинників активності на окремі ії компоненти, та Ґрунтується на методології системного аналізу, методах дослідження операцій, аналізу ієрархій, прогнозування, програмно-цільового планування, експертного оцінювання та моделювання, що дозволяє розробляти найбільш оптимальні варіанти досягнення цільових параметрів активності у фінансовій, виробничій, кадровій, ринковій, інноваційній, інвестиційній та управлінській сорерах. Ії̈ використання в управлінській практиці підприємств ритейлу сприятиме підвищенню ефективності стратегічного планування через можливість:

- здійснювати системне дослідження та обґрунтування основ політик управління забезпеченням економічної активності та її окремих складових, цілей, принципів, пріоритетних напрямів та механізмів досягнення визначених цілей;

- формувати множину варіантів моделі стратегічного планування забезпечення економічної активності, структура і значення елементів яких відповідають прийнятному рівню забезпечення активізації діяльності підприємства в управлінській, фрінансовій, виробничій, кадровій, ринковій, інноваційній та інвестиційній сферах;

- ідентифікувати та діагностувати загрозливі чинники зміни економічної активності у зовнішньому та внутрішньому середовищі;

- моделювати основні процеси стратегічного планування та визначати реальні можливості підприємства із досягнення цільового рівня економічної активності в умовах динамічних змін бізнес-оточення та уподобань споживачів.

Перспектива подальших наукових пошуків полягає в розробці стратегії активізації економічної діяльності торговельного підприємства з урахуванням основних положень запропонованої концептуальної ієрархічної моделі стратегічного ії планування.

\section{Список використаних джерел:}

1. Кащена, Н.Б. (2019). Моделювання процесу стратегічного управління економічною активністю торговельного підприємства. Інфраструктура ринку, (34), 125-134. Вилучено 3 http://www.market-infr.od.ua/journals/2019/34_2019_ukr/20.pdf

2. Семенченко, А.І. (2009) Комплексна модель стратегічного планування у державному управлінні сферою національної безпеки. Стратегічна панорама, (1), 56-66.

3. Карпіщенко, О.І., Ілляшенко К.В. \& Карпіщенко О.О. (2013). Стратегічне планування. Суми: Сумський державний университет.

4. Саати, Т. (1996). Принятие решений. Метод анализа иерархий. Москва: Радио и связь.

5. Саати, Т. \& Кернс К. (1991). Аналитическое планирование: Организация систем. Москва. 


\section{СУБ’ЄКТИ ПУБЛІЧНОГО АДМІНІСТРУВАННЯ В СФЕРІ ОПОДАТКУВАННЯ}

\section{Голобородько Тетяна Василівна}

канд. екон. наук, старший викладач кафедри обліку, оподаткування, публічного управління та адміністрування Криворізький національний університет

УКРАЇHA

Податковим кодексом України [5] визначено, що адміністрування податків, зборів, митних платежів, єдиного внеску здійснюється контролюючими органами. На законодавчому рівні також визначено, що контролюючим органом $€$ центральний орган виконавчої влади, що реалізує державну податкову та митну політику, його територіальні органи. Таким чином, основними суб'єктами публічного адміністрування у сфері оподаткування $є$ Державна податкова служба України та Державна митна служба України, діяльність яких спрямовується і координується Кабінетом Міністрів України через Міністра фрінансів.

Основні етапи становлення контролюючих органів в Україні умовно можна представити шістьма етапами (табл. 1).

Таблиця 1

\section{Основні етапи становлення контролюючих органів}

\begin{tabular}{|c|c|l|l|}
\hline Етап & Період & \multicolumn{3}{|c|}{ Характеристика } \\
\hline Перший & $1990-1996$ рр. & $\begin{array}{l}\text { Створення Державної податкової інспекції України у складі } \\
\text { Міністерства фінансів }\end{array}$ \\
\hline Другий & $1996-2000$ pp. & $\begin{array}{l}\text { Утворення Державної податкової адміністрації як } \\
\text { самостійного органа виконавчої влади, зміна рівня } \\
\text { підпорядкування податкової служби }\end{array}$ \\
\hline Третій & $2000-2011$ рp. & $\begin{array}{l}\text { Модернізація та реорганізація податкової службу рамках } \\
\text { євро інтеграції України }\end{array}$ \\
\hline Четвертий & $2012-2014$ рр. & $\begin{array}{l}\text { Створення Міністерства доходів та зборів, шляхом } \\
\text { об'єднання Податкової та Митної служб }\end{array}$ \\
\hline П'ятий & $2014-2018$ рр. & $\begin{array}{l}\text { Створення Державної фріскальної служби шляхом } \\
\text { реорганізації Міністерства доходів і зборів }\end{array}$ \\
\hline Шостий & 2019 р. & $\begin{array}{l}\text { Реорганізація Державної фіскальної служби та утворення } \\
\text { Державної податкової служби України та Державної митної } \\
\text { служби України }\end{array}$ \\
\hline
\end{tabular}

Дані сформовано з $[4$, c.50-51;6]

ДФС України, як центральний орган виконавчої влади, об’єднує підрозділи з митної справи та податкові органи, що має аналоги в європейській та світовій практиці (зокрема, в Королівстві Нідерландів, Данії, Естонії, Угорщині, Канаді) [2]. Таке об'єднання у 2014 році несло значні позитивні перспективи:

1. Об'єднання митної і податкової служб України в єдиний фіскальний орган, який нестиме усю повноту відповідальності за процес адміністрування податків, зборів та інших соціальних платежів, свідчить про прагнення і нашої держави удосконалити та встановити більш посилений контроль за формуванням державного бюджету, прямуючи вже перевіреним і достатньо вдалим шляхом багатьох європейських країн [13]. 
2. Створення такого якісно нового органу $є$ одним із важливих кроків нашої держави на шляху до європейської інтеграції [7].

Однак, досвід такого об'єднання в Україні $€$ негативним внаслідок неефективного управління та фіскалізації діяльності митних органів [2].

Поряд 3 цим, здійснюючи глибокий аналіз концепції реалізації державної політики у сфері державної митної справи підрозділами та органами митного спрямування державної фріскальної служби України, Федотов О.П., доводить, що «підрозділи апарату та територіальні органи митного спрямування ДФС України не отримали ні інновацій, ні бодай якихось покращень для поліпшення ситуації в питаннях прозорої реалізації державної політики у сфері державної митної справи. Уся публічність сходиться кутом на призначенні одних очільників ДФС України та звільненні з посад чи виходу у відставку інших» [10].

Саме тому, найбільш прогнозованим було повернення розподільної структури контролюючих органів.

Основними напрямами щодо покращення ефективності діяльності суб'єктів публічного управління та адміністрування в сфері оподаткування $є$ :

- вдосконалення консультативно-роз'яснювальної роботи шляхом подальшої трансформації контролюючого органу в сервісну службу [9; 1];

- необхідність забезпечення належних гарантій нормального функціонування вже наявних форм дорадчої демократії [12];

- забезпечення високоефективного громадський моніторинг за діяльністю контролюючих органів [11; 8; 3].

До зазначеного: продовження автоматизації адміністрування у сфері оподаткування зменшить корупційну складову в цій сфері.

\section{Список використаних джерел:}

1. Державна фріскальна служба України: на шляху реформ. Вилучено $3 \mathrm{https:}$ http://sfs.gov.ua/data/material/000/153/214278/Presentazia.pdf.

2. Дроговоз, Ю., Дубровський, В. Інституційні проблеми української податкової системи та $\begin{array}{llll}\text { шляхи } і ̈ x & \text { вирішення. }\end{array}$ https://rpr.org.ua/uploads/files/source/Проблеми\%20української20податковоі\%20системи\% 20та\%20шляхи\%20ї\%20вирішення\%20-\%20fina\%2006-09-15.pdf.

3. Дроговоз, Ю., Черніков, Д. Як та навіщо реформувати державну фоскальну службу України. Вилучено з http://euinfocenter.rada.gov.ua/uploads/documents/28826.pdf.

4. Андрущенко, В.Л. (2015). Податкова система. Вилучено 3 https://cul.com.ua/preview/psa.pdf.

5. Податковий кодекс України (2010). Вилучено з http://zakon.rada.gov.ua.

6. Про утворення Державної податкової служби України та Державної митної служби України (Постанова Кабінету Міністрів України). № 1200. Вилучено 3 https://www.kmu.gov.ua/npas/pro-utvorennya-derzhavnoyi-podatkovoyi-sluzhbi-ukrayini-taderzhavnoyi-mitnoyi-sluzhbi-ukrayini.

7. Лепеха, А. (2016). Принципи модернізації державного управління фіскальною сферою в Україні. Державне управління та місцеве самоврядування. (4), 57-62. Вилучено 3 http://www.dridu.dp.ua/vidavnictvo/2016/2016_04(31)/10.pdf.

8. Руденко, Ю. М. (2017). Громадський контроль у процесах реформування податкової системи в Україні в сучасних умовах. Інвестиції: практика та досвід. (21), 100-104. Вилучено 3 http://nbuv.gov.ua/UJRN/ipd_2017_21_24. 
9. Теремецький, В. І. (2015). Проблема вдосконалення консультативно-роз'яснювальної роботи територіальними органами державної фіскальної служби України. Вісник Академії адвокатури України. (12, 3), 39-47. Вилучено з http://nbuv.gov.ua/UJRN/vaau_2015_12_3_7.

10. Федотов, О. П. (2015) Концепція реалізації державної політики у сфері державної митної справи підрозділами та органами митного спрямування Державної фіскальної служби України. Юридична наука. (7), 52-63. Вилучено з http://nbuv.gov.

11. Хомов, С.М.(2015) Громадський моніторинг як форма громадського контролю за діяльністю Державної фіскальної служби України. Часопис Академії адвокатури України. (8,4), 138143. Вилучено 3 http://nbuv.gov.ua/UJRN/Chaau_2015_8_4_14.

12. Чорна, А. М. (2015) Напрями удосконалення взаємодії органів державної фіскальної служби з іншими державними органами та громадськістю з питань забезпечення прав суб'єктів підприємницької діяльності у сфрері оподаткування. Прикарпатський юридичний вісник. (3), 255-258. Вилучено 3 http://nbuv.gov.ua/UJRN/Pjuv_2015_3_57.

13. Шулатова, І. С. (2015) Передумови становлення Державної фіскальної служби України. Збірник наукових праць Харківського національного педагогічного університету імені $Г$.
C.
Сковороди.
«Право».
(23),
110-116.
Вилучено
3

http://nbuv.gov.ua/UJRN/znpkhnpu_pravo_2015_23_16. 


\section{$\Lambda \mathrm{O} \mathrm{O} \mathrm{O}$}

COLLECTION DE PAPIERS SCIENTIFIQUES

\section{SUR LES MATÉRIAUX DE LA CONFÉRENCE SCIENTIFIQUE ET PRATIQUE INTERNATIONALE «PROBLÈMES ET PERSPECTIVES D'INTRODUCTION DE LA RECHERCHE SCIENTIFIQUE INNOVANTE» 20 novembre 2019 • Bruxelles, Belgique VOLUME 1}

Ukrainien, russe, français, anglais et allemand

Les matériaux sont imprimés dans le texte de l'auteur Le comité organisateur ne partage pas toujours la position des auteurs Pour l'exactitude de ce matériel, les auteurs portent la responsabilité

Signé pour impression le 29.11.2019. Format $60 \times 84 / 16$.

Papier offset. Arial type. Impression numérique

Feuilles imprimées conditionnées 7,56 .

Un tirage de 100 exemplaires.

Imprimé à partir de la mise en page originale finie.

Coordonnées du comité d'organisation:

21037, Ukraine, Vinnytsia, st. Zodchih, 18, bureau 81

Plateforme scientifique européenne

Téléphones: +38 098 1948380; +38098 1956755

E-mail: info@ukrlogos.in.ua

www.ukrlogos.in.ua | www.ojs.ukrlogos.in.ua 